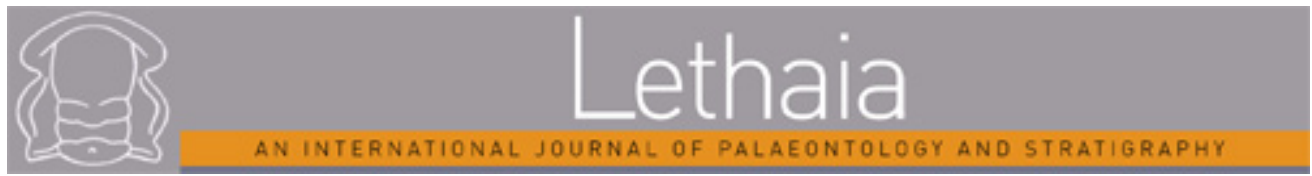

\title{
Ontogenetic trajectories of septal spacing in modern cuttlefishes are phylogenetically dependent
}

\begin{tabular}{|r|l|}
\hline Journal: & Lethaia \\
\hline Manuscript ID & 0911-LET-OA-10-19.R1 \\
\hline Manuscript Type: & Original Article \\
\hline Author: & n/a \\
\hline Complete List of Authors: & $\begin{array}{l}\text { Noba, Kazuki; Yokohama National University, Graduate School of } \\
\text { Environment and Information Sciences } \\
\text { Yasumuro, Haruhiko; Kobe Animals-and-Plants Environmental College } \\
\text { Ikeda, Yuzuru; University of the Ryukyus, Faculty of Science } \\
\text { Wani, Ryoji; Yokohama National University, Faculty of Environment and } \\
\text { Information Sciences }\end{array}$ \\
\hline Keywords: & septal spacing, ontogenetic trajectory, Sepiidae, Sepia, Sepiella \\
\hline &
\end{tabular}




\section{Ontogenetic trajectories of septal spacing in modern cuttlefishes are}

\section{2 phylogenetically dependent}

3

4

5

6

\section{KAZUKI NOBA, HARUHIKO YASUMURO, YUZURU IKEDA AND RYOJI WANI}

8 Noba, K., Yasumuro, H., Ikeda, Y. \& Wani, R. ****: Ontogenetic trajectories of septal spacing in modern cuttlefishes are phylogenetically dependent. Lethaia, Vol. **, pp. ***_***.

2 In this study, the ontogenetic trajectories of septal spacing between succeeding chambers of five

modern cuttlefishes; Sepia esculenta; S. lycidas; S. latimanus; S. pharaonic; and Sepiella japonica,

4 which were all wild-caught around Japan, were analysed. The ontogenetic trajectories of septal

5 spacing of all examined cuttlefishes demonstrate a decrease in septal spacing followed by an

6 increase during the earliest ontogenetic stage. This trend is assumed to be related to hatching. After

17 the rapid decrease and increase in septal spacing, species-dependent trends occur irrespective of sex and locality. Based on cluster analyses of general trends recognised in each species, the five

examined species can be categorised into two groups: (1) a group by $S$. pharaonis, $S$. esculenta, and 
20 Sepiella japonica and (2) S. latimanus and S. lycidas as more distant branching groups within the

21 five examined species. This classification is concordant with some phylogenetic clades determined

22 from DNA analyses. Therefore, we hypothesised that the ontogenetic trajectories of septal spacing

23 among modern cuttlefishes are phylogenetically dependent. If this hypothesis holds in fossil

24 cuttlefishes, the examination of ontogenetic trajectories of septal spacing would give new insight

25 into the recognition not only of the life history but also of the phylogeny of fossil cuttlefishes.

26 septal spacing, ontogenetic trajectory, Sepiidae, Sepia, Sepiella.

Kazuki Noba, Graduate School of Environment and Information Sciences, Yokohama National

University, Yokohama 240-8501, Japan; Haruhiko Yasumuro, Kobe Animals-and-Plants

31 Environmental College, Kobe 658-0032, Japan; Yuzuru Ikeda, Faculty of Science, University of the

32 Ryukyus, Okinawa 903-0213, Japan; Ryoji Wani [wani@ynu.ac.jp], Faculty of Environment and

33 Information Sciences, Yokohama National University, 79-7, Tokiwadai, Hodogaya-ku, Yokohama

34 240-8501, Japan; manuscript received on **/**/****; manuscript accepted on **/**/****.

Modern cuttlefishes have septate internal shells that serve as buoyancy devices (Denton \&

38 Gilpin-Brown 1964, 1971; Denton et al. 1967). These internal shells have septa, which divide the 
39 shells into phragmocones used to regulate buoyancy. As coleoids grow, new septa are formed

40 within their internal shells, generating a record of growth progress. Little attention to date has been

41 devoted to the study of modern cuttlebones and their ontogenetic analysis (Hewitt \& Stait 1988;

42 Yamaguchi et al. 2015). The ontogenetic trajectories of septal spacing have been demonstrated in

43 only a couple of species: Sepia officinalis in the study by Hewitt \& Stait (1988) and Sepiella

44 japonica in the study by Yamaguchi et al. (2015). Therefore, it is as yet unknown whether there are

45 common features among modern cuttlefishes related to the ontogenetic trajectories of septal 46 spacing.

48 dedicated to ontogenetic analysis of the septate external shell morphology of modern nautiloids

49 (Landman et al. 1983; Collins \& Ward 1987; Tanabe \& Tsukahara 1987; Landman 1988; Klug

50 2004; Chirat et al. 2008; Klug et al. 2008; Tajika et al. 2015, 2018; Lemanies et al. 2016), fossil

51 nautiloids (i.e. the order Nautilida; Ruzhencev \& Shimansky 1954; Davis \& Mohorter 1973;

52 Landman et al. 1983; Landman 1988; Chirat \& Rioult 1998; Chirat 2001; Wani \& Ayyasami 2009;

53 Wani \& Mapes 2010) and ammonoids (Kulicki 1974; Doguzhaeva 1982; Checa 1987; Landman

54 1987; Dommergues 1988; Bucher et al. 1996; Okamoto \& Shibata 1997; Korn \& Titus 2006;

55 Ebbighausen \& Korn 2007; Kraft et al. 2008; Arai \& Wani 2012; Tajika et al. 2014, 2015; Naglik

56 et al. 2015; Lemanies et al. 2015, 2016; Iwasaki et al. 2020). In Late Cretaceous ammonoids from 57 Hokkaido, Japan, for example, Arai \& Wani (2012) found various patterns of ontogenetic 
58 trajectories of septal spacing and suggested that these patterns tend to conform to higher taxonomy

59 and are generally uniform within each superfamily (see Iwasaki et al. 2020 for the exception). In

60 modern and fossil nautiloids (the order Nautilida), Wani \& Mapes (2010) suggested that the

61 ontogenetic trajectories of septal spacing are conservatively uniform, irrespective of taxonomy and

62 age. Although such similarities have been recognised in cephalopods with external shells

63 (ammonoids and nautiloids), no information is as yet available for cephalopods with internal shells.

65 modern sepioid cuttlefishes, this study examined five species. The ontogenetic trajectories of septal

66 spacing were compared among these species to examine their implications for the life history and 67 phylogeny of cuttlefishes.

\section{Material}

71 Cuttlebones of Sepia esculenta Hoyle, 1885 (10 specimens); S. lycidas Gray, 1849 (five specimens);

72 S. latimanus Quoy and Gaimard, 1832 (two specimens); S. pharaonis Ehrenberg, 1831 (nine

73 specimens); Sepiella japonica Sasaki, 1929 (11 specimens), were used in this study for the analyses 74 of septal spacing (Table S1).

All specimens were wild caught (Fig. 1; Table S1). Specimens of S. esculenta were

76 caught off the Nagasaki Prefecture (five specimens) and in the Sea of Harima (five specimens) in 
77 Japan. Specimens of S. lycidas were caught in the Sea of Harima. Specimens of S. latimanus were

78 caught off Okinawa-jima Island, Japan. Specimens of S. pharaonis were caught off Okinawa-jima

79 Island. Specimens of Sepiella japonica were caught in the Sea of Harima. Detailed environmental around Japan are 360 and $500 \mathrm{~mm}$, respectively (Okutani 1979a, b), and species of this size two-year life cycle is more than 400 (Dan et al. 2012). Considering the observed mantle length and 95 total septal number of each examined specimen of S. pharaonis and S. latimanus (Table S1), these

The life cycles of S. esculenta, S. lycidas and Sepiella japonica are known to be one year, whereas those of S. pharaonis and S. latimanus are one or two years (Okutani 1979b; Aoyama \& Nguyen 1989; Nabhitabhata \& Nilaphat 1999; Dan et al. 2012). The maximum cuttlebone length and the septal number of examined S. pharaonis is $217 \mathrm{~mm}$ and 203, respectively, and the maximum mantle length and the septal number of examined S. latimanus are $276 \mathrm{~mm}$ and 224 , respectively (Table S1). The known maximum mantle lengths of $S$. pharaonis and S. latimanus probably have two-year life cycles. The maximum number of septa of mature $S$. latimanus having a 
96 facts suggest that the life cycles of all examined specimens of S. pharaonis and S. latimanus are not

97 two years but one year. Therefore, this study examined and compared the ontogenetical trajectories

98 of septal spacing among five species of modern cuttlefishes around Japan whose life cycles were all 99 one year.

All specimens are housed in the collections of the Mikasa City Museum, Hokkaido,

Japan.

\section{Note on phylogeny of the five examined species}

The phylogenetic affinity of modern sepiids (including the five examined species) has been

estimated based on DNA analyses (Bonnaud et al. 2006; Yoshida et al. 2006, 2010; Anderson et al.

2011; Dai et al. 2012; Lindgren et al. 2012; Sanchez et al. 2016; Lü et al. 2019). However, the

phylogeny of the five examined species has been still controversial and therefore a consensus of the phylogeny of the five examined species is not obtained (Fig. 2). For example, some studies have suggested S. latimanus and S. lycidas as paraphyletic (Bonnaud et al. 2006; Anderson et al. 2011), although the other have suggested that they are monophyletic with other three species (Yoshida et al. 2006, 2010; Dai et al. 2012). Such discrepancy of the supposed phylogeny seems to be possibly 


\section{Septal distance}

116 The cuttlebones of the examined species were first embedded in transparent epoxy resin to avoid damage to the thin septa. Then, the cuttlebones were cut along the median line. Cuttlebone longitudinal sections were examined under a digital microscope (Keyence VHX-900, with a magnification of $\times 25-\times 175$ ), and distances between succeeding septa were measured from the median point of the septa, perpendicular to the previous septum (Fig. 3A). The measured septal spacing is shown in comparison to the septal number. These graphs define the ontogenetic trajectories of septal spacing for the examined cuttlefishes.

\section{Cluster analysis}

To categorize the ontogenetic trajectories of septal spacing among the five examined, cluster analyses of septal spacing data versus the septal number were performed to calculate the Euclidean distance. First, cluster analyses were performed with the averages of septal spacing in each species with Ward's method, which is a popular method of cluster analyses. Then, cluster analyses were performed with the septal spacing of all the examined specimens only with Ward's method. 
134 This study defined and used five basic parameters representing the shape of the cuttlebone.

\section{Results}

Sepia esculenta. - In this study, specimens from two areas (five specimens caught off the Nagasaki

Prefecture and five specimens caught in the Sea of Harima) were examined (Figs. 4, 5A, B).

For the specimens caught off the Nagasaki Prefecture, the septal spacing for S. esculenta

showed that the distances between septa follow a general decrease from the 1st septum

(mean \pm standard deviation [SD]; $0.15 \pm 0.027 \mathrm{~mm})$ to the 8 th septum $(0.09 \pm 0.015 \mathrm{~mm})$, a subsequent

gradual increase from the 9 th septum $(0.11 \pm 0.014 \mathrm{~mm})$ to the 100 th septum $(0.41 \pm 0.035 \mathrm{~mm})$, and

then a slight decrease from the 101st septum (with a larger standard deviation; Fig. 4). The standard deviations of measurements between septa decreased from the 1st septum to the 11th septum and then increased gradually.

For the specimens caught in the Sea of Harima, the septal spacing for S. esculenta

showed that the distances between septa follow a general decrease from the 1 st septum

(mean \pm standard deviation; $0.16 \pm 0.026 \mathrm{~mm})$ to the 8 th septum $(0.10 \pm 0.012 \mathrm{~mm})$, a subsequent gradual increase from the 9 th septum $(0.10 \pm 0.007 \mathrm{~mm})$ to the 100 th septum $(0.40 \pm 0.046 \mathrm{~mm})$, and 
153 then a decrease from the 101st septum (with a larger standard deviation; Fig. 4). The standard

154 deviations of measurements between septa decreased from the 1st septum to the 10th septum and

155 then increased gradually.

The ontogenetic trajectories of septal spacing in the specimens from both localities were

basically comparable and overlapped throughout almost the entire ontogeny (Fig. 4), although some specimens showed irregular septal spacing at some ontogenetic stages.

Sepia lycidas. - The septal spacing for S. lycidas showed that the distances between septa follow a general decrease from the 1 st septum (mean \pm standard deviation; $0.20 \pm 0.002 \mathrm{~mm}$ ) to the 9 th septum $(0.15 \pm 0.035 \mathrm{~mm})$, a subsequent increase from the 10 th septum $(0.19 \pm 0.017 \mathrm{~mm})$ to the $102 \mathrm{nd}$ septum $(0.54 \pm 0.017 \mathrm{~mm})$, and then a decrease from the $103 \mathrm{rd}$ septum (with a larger standard deviation; Figs. 5C, D). The standard deviations of measurements between septa decreased from the 1 st septum to the 10th septum and then increase gradually.

Sepia latimanus. - The septal spacing for S. latimanus showed that the distances between septa

followed a general decrease from the 1 st septum (mean \pm standard deviation; $0.19 \pm 0.005 \mathrm{~mm}$ ) to the 17th septum $(0.08 \pm 0.028 \mathrm{~mm})$, a subsequent increase from the 18 th septum $(0.10 \pm 0.004 \mathrm{~mm})$ to the 99th septum $(0.48 \pm 0.007 \mathrm{~mm})$, and then a decrease from the 100th septum to the 166 th septum

(Figs. 5E, F).The septal spacing in addition showed another cycle of increasing to decreasing 
172 spacing: an increase from the 167 th septum to the 187 th septum $(0.36 \pm 0.069 \mathrm{~mm})$; and a decrease 173 thereafter (Figs. 5E, F).

Sepia pharaonis. - The septal spacing for wild specimens of S. pharaonis showed that the distances between septa followed a general decrease from the 1st septum (mean \pm standard deviation;

$0.13 \pm 0.030 \mathrm{~mm})$ to the 10 th septum $(0.10 \pm 0.022 \mathrm{~mm})$ and a subsequent linear increase from the 11th septum $(0.11 \pm 0.018 \mathrm{~mm})$ to the 58 th septum $(0.40 \pm 0.041 \mathrm{~mm})$. The measurements between septa from the 59th septum to the 164th septum were maintained between $0.34 \mathrm{~mm}$ and $0.42 \mathrm{~mm}$, followed by a linear decline from the 165 th septum (Figs. 6A, B). The standard deviations of measurements between septa decreased from the 1st septum to the 11th septum and then increased gradually.

Sepiella japonica. - The septal spacing for Sepiella japonica showed that the distances between septa followed a general decrease from the 1 st septum (mean \pm standard deviation; $0.20 \pm 0.056 \mathrm{~mm}$ ) to the 8 th septum $(0.09 \pm 0.030 \mathrm{~mm})$ and a subsequent linear increase from the 9 th septum

$(0.12 \pm 0.046 \mathrm{~mm})$ to the 47 th septum $(0.33 \pm 0.037 \mathrm{~mm})$. The measurements between septa from the 48th septum to the 135 th septum were maintained between $0.31 \mathrm{~mm}$ and $0.39 \mathrm{~mm}$, followed by a linear decline from the 136th septum (Figs. 6C, D). The standard deviations of measurements between septa decreased from the 1st septum to the 8th septum and then increased gradually. 
192 Cluster analysis

193 The results of the cluster analyses with the average septal trajectories of the five examined species 10

can be classified into two groups: one group is composed by S. pharaonis, S. esculenta, and

Sepiella japonica, and the other group is composed by S. latimanus and S. lycidas (Fig. 7A).

The results of the cluster analyses with the septal spacing of all the examined specimens

(Fig. 7B) can be classified into three groups (Fig. 7C). The first group is composed by the mixture of $S$. pharaonis, S. esculenta, and Sepiella japonica, the second is composed by the mixture of $S$.

pharaonis, S. esculenta, and S. latimanus, and the third is composed by mainly S. lycidas with one specimen of $S$. pharaonis.

\section{Shell morphology}

The scatter diagrams of the five examined parameters of shell morphology indicate that cuttlebone shape tends to be species-dependent (Fig. 8).

\section{Discussion}

Common characteristics in ontogenetic trajectories of septal spacing among modern cuttlefishes

The results of this study, based on measurements of septal spacing of more than 5,600 septa in total 
210 from five species of modern cuttlefish, revealed the characteristics of the ontogenetic trajectories of 5

211 septal spacing (Figs. 2-4). These results suggest species-dependent general trends. For Sepia

9212 esculenta, this study compared specimens from two localities (Nagasaki vs. Sea of Harima; Fig. 2).

12213 The ontogenetic trajectories of septal spacing between the two localities demonstrated a similar

15214 tendency, overlapping each other for most ontogenetic stages (Fig. 2). All environmental conditions

(seawater temperature; habitat depth, or the equivalent condition of hydrostatic pressure; and conditions of food) between the two localities could not be assumed to be totally equivalent.

Although it is unknown how the environmental conditions differ, they seem to have little

importance in controlling the ontogenetic trajectories of septal spacing, at least in the examined

specimens of S. esculenta. In contrast, Hewitt \& Stait (1988) found a correlation of septal spacing with ambient water temperature, which argues for an environmental control of septal spacing. Such relationship between cuttlebone growth, including septal spacing, and water temperature is possibly exaggerated under a limited food condition (Martínez et al. 2000). Considering these literatures, the food conditions of the examined specimens of $S$. esculenta were postulated to be not scarce, which therefore possibly minimized the environmental control of septal spacing. In the other four species

(S. lycidas, S. latimanus, S. pharaonis, and Sepiella japonica), the environmental control of septal spacing cannot be determined, because detailed environmental information (e.g. seawater temperature and depth) of the areas where these animals lived is currently unknown. However, we also hypothesised little importance in controlling the ontogenetic trajectories of septal spacing in the 
other four species. This is because no irregular shell shape and shell growth found in the examined specimens implies that they lived in enough food conditions and because some specimens were caught in the area same with those of S. esculenta (i.e. the Sea of Harima; Table S1), possibly resulting in the minimized environmental control of septal spacing.

In addition to the comparison of locality, this study examined the influence of sex (male vs. female). Both male and female cuttlefishes were examined in the S. esculenta, S. lycidas, S. latimanus, and S. pharaonis groups (Table S1). The ontogenetic trajectories of septal spacing of both sexes in each species are similar (Figs. 2-4), which implies that these trajectories in each species of cuttlefishes develop irrespective of sex. However, the examined numbers of specimens are limited, so that it should be confirmed with abundant specimens in future studies whether the trajectories of septal spacing in each species are irrespective of sex.

A common feature among the five examined species can be discerned, which is the presence of a decrease in septal spacing followed by an increase during the earliest ontogenetic stage (8th-17th septum, depending on the species; Figs. 2-4). Based on the reared specimens, modern cuttlefishes are known to hatch with several chambers, demonstrating that $S$. esculenta, $S$. lycidas, S. pharaonis, and Sepiella japonica hatch with 6-8, 7-11, 5-6, and $7-9$ chambers, respectively (Choe 1962; Chung \& Wang 2013). Among S. latimanus, the mantle length of hatchlings is $11-15 \mathrm{~mm}$ (Okutani 1978), which would approximately correspond to 15-20 septa at hatching based on the relationship between mantle length and numbers of septa recorded through 
248 the measurements of this study. Therefore, the decrease in septal spacing followed by an increase

249 during the earliest ontogenetic stage, is thought to be related to the hatchings in each species of cuttlefishes.

\section{Categories of ontogenetic trajectories of septal spacing among modern cuttlefishes}

Species-dependent general trends of ontogenetic trajectories of septal spacing among the examined cuttlefishes enable us to categorise cuttlefish species based on similarity or dissimilarity to these general trends. The results of cluster analyses can be categorized into two cluster patterns (Fig. 7A, B). The first pattern is seen in the results of the cluster analyses with the average septal trajectories of the five examined species with Ward's method (Fig. 7A), in which there are two groups: one group by S. pharaonis, S. esculenta, and Sepiella japonica, and the other group by S. latimanus and S. lycidas. The second pattern is seen in the results of the cluster analyses with the septal spacing of all the examined specimens (Fig. 7B, C). In this cluster pattern, there is a group by $S$. pharaonis, $S$. esculenta, and Sepiella japonica with S. latimanus and S. lycidas as more distant branching groups within the five examined species. Some specimens of S. pharaonis and S. esculenta represent similar pattern with $S$. latimanus and S. lycidas due to their intraspecific variations of septal spacing (Fig. 7B, C). In any case, these two patterns commonly suggest that S. latimanus and S. lycidas represent more distant branching groups than S. pharaonis, S. esculenta, and Sepiella japonica. These two cluster patterns of septal spacing are recognised irrespective of taxonomic 
2

assignment at the genus level, because Sepiella japonica is categorised is the group together with two species of the genus Sepia (S. pharaonis and S. esculenta; Fig. 7). The phylogenetic affinity of cephalopods (including modern cuttlefishes) has been estimated based on DNA analyses (Bonnaud et al. 2006; Yoshida et al. 2006, 2010; Anderson et al. 2011; Dai et al. 2012; Lindgren et al. 2012; Sanchez et al. 2016), indicating that a consensus of the phylogeny of the five examined species is not obtained (Fig. 2). Some studies have suggested S. latimanus and S. lycidas as paraphyletic (Bonnaud et al. 2006; Anderson et al. 2011; Fig. 2A, D), which are concordant with the two cluster patterns recognised in this study based on the general trends of ontogenetic trajectories of septal spacing. Based on this concordance in plural phylogenetic trees among eight literatures (Bonnaud et al. 2006; Yoshida et al. 2006, 2010; Anderson et al. 2011; Dai et al. 2012; Lindgren et al. 2012; Sanchez et al. 2016; Lü et al. 2019), therefore, we hypothesised that the ontogenetic trajectories of septal spacing among modern cuttlefishes are phylogenetically dependent. However, several phylogenetic trees are not all concordant with the two cluster patterns based on the general trends of ontogenetic trajectories of septal spacing (Fig. 2B-C, E-G, H). Lindgren et al. (2012) used the relatively complete dataset in terms of the relevant factors (the number of species and number of analysed sequences). The phylogenetic tree of Lindgren et al. (2012), however, does not reflect the two cluster patterns of this study (Figs. 2E, 7). A recent study of sepiid phylogeny based on whole mitochondrial genomes (Lü et al. 2019) showed a phylogenetic pattern, which is also not concordant with the two cluster patterns of this study (Figs. 2H, 7). The reason of these 
286 discrepancies is possibly unexpected confusion about genus Sepia and Sepiella, which comes from

287 the unsolved classification in sepiid species (Yoshida et al. 2006; Lü et al. 2019). Further

investigations of DNA classification of modern sepiids, which result in a consensus of the sepiid

phylogeny, and of ontogenetic trajectories of septal spacing with more abundant species would be

able to solve such discrepancy and to examine the validity of our hypothesis.

Finally, to investigate the factors most closely related to the recognised cluster patterns,

cuttlebone shapes of the five examined species were compared in this study (Fig. 5; Table S1). The

scatter diagrams of cuttlebone shapes of the five examined species indicate that cuttlebone shape

cannot be categorised into two groups similar to the recognised cluster patterns (S. pharaonis, $S$.

esculenta, and Sepiella japonica, and S. latimanus and S. lycidas; Fig. 7). These facts suggest that the two clusters of septal spacing are recognised irrespective of cuttlebone shape. Bonnaud et al.

(2006) suggested the shell shape of sepiids is not phylogenetically informative, due to their

plasticity, which is concordant to the speculation of this study. Therefore, the adult shape only is not as informative as the ontogenetic patterns of septal spacing to reconstruct the phylogeny.

\section{Implications for fossil cephalopods}

A decrease in septal spacing followed by an increase during the earliest ontogenetic stage can be observed among all examined modern cuttlefishes (8th-17th septum, depending on the species; Figs.

2-4). This common feature is assumed to be related to hatching in each species of cuttlefishes. 

4 5

20

Similar relationships between hatching and decreased septal spacing followed by increased septal spacing during the earliest ontogenetic stage have been recognised in other cephalopods (modern spirula and modern and fossil nautiloids (the order Nautilida); Landman et al. 1983; Tanabe \& Tsukahara 1987; Arnold et al. 1987; Chirat \& Rioult 1998; Wani \& Ayyasami 2009; Wani \& Mapes 2010; Yamaguchi et al. 2015). These facts suggest that such a relationship is one common characteristic among cephalopods, except for ammonoids and belemnites (both are assumed to hatch with a protoconch and no chamber; Landman et al. 1996; Arai \& Wani 2012; De Baets et al. 2015; Wani et al. 2018).

This relationship between hatching and decreased septal spacing followed by increased

septal spacing during the earliest ontogenetic stage would possibly enable us to recognise the hatching timing for fossil cuttlefishes. If preservation permitted analysis of the ontogenetic trajectories of septal spacing of fossil cuttlefishes, it is highly likely that the examined cuttlefishes hatched with septal spacing which decreased and followed by increased septal spacing during the earliest ontogenetic stage. The hatching timing of fossil cuttlefishes has rarely been discussed until now. The examination of ontogenetic trajectories of septal spacing would give new insight into recognition of the life history of fossil cuttlefishes.

This study also hypothesized that the species-dependent general trends of ontogenetic trajectories of septal spacing in modern cuttlefishes reflect phylogenetic affinity, making them more reliable indicators than cuttlebone shape. This is concordant with the suggestion in Bonnaud et al. 
324 (2006) that shell characters of modern sepiids are not phylogenetically informative. If this

325 hypothesis holds in fossil cuttlefishes, the examination of ontogenetic trajectories of septal spacing would enable us to recognise the phylogenetic resemblance of fossil cuttlefishes. DNA examination of fossil cuttlefishes would be difficult in most cases. Thus, examination of ontogenetic trajectories of septal spacing would give insight into the recognition of the phylogeny of fossil cuttlefishes, if preservation permitted.

Acknowledegments. - We are grateful to C. Sugimoto and T. Kinjo for their donations of some

examined specimens, T. Iwasaki for his advice on cluster analyses, and to D. Aiba for his help in accessing specimens studied in Yamaguchi et al. (2015), deposited in the Mikasa City Museum. We sincerely thank two anonymous reviewers for their valuable and thoughtful comments on an earlier draft of the manuscript.

\section{Supporting Information}

Additional supporting information may be found online in the Supporting Information section at the end of the article.

Table S1. Measurement data for septal spacing and shell morphology. 


\section{References}

345 Anderson, F.E., Engelke, R., Jarrett, K., Valinassab, T., Mohamed, K.S., Asokan, P.K., Zacharia, P.U., Nootmorn, P., Chotiyaputta, C. \& Dunning, M. 2011: Phylogeny of the Sepia pharaonis species complex (Cephalopoda: Sepiida) based on analyses of mitochondrial and nuclear DNA sequence data. Journal of Molluscan Studies 77, 65-75.

Aoyama, T. \& Nguyen T. 1989: Stock assessment of cuttlefish off the coast of the People's Democratic Republic of Yemen. Journal of Shimonoseki University of Fisheries 37, $61-112$.

Arai, K. \& Wani, R. 2012: Variable growth modes in Late Cretaceous ammonoids: implications for diverse early life histories. Journal of Paleontology 86, 258-267.

Arnold, J.M., Landman, N.H. \& Mutvei. H. 1987: Development of the embryonic shell of Nautilus. In Saunders, W.B. \& Landman, N.H. (eds.): Nautilus, 373-400. Plenum Press, New York.

Bonnaud, L., Lu, C.C. \& Boucher-Rodoni, R. 2006: Morphological character evolution and molecular trees in sepiids (Mollusca: Cephalopoda): is the cuttlebone a robust phylogenetic marker? Biological Journal of the Linnean Society 89, 139-150.

Bucher, H., Landman, N.H., Guex, J. \& Klofak, S.M. 1996: Mode and rate of growth in ammonoids. In Landman, N.H., Tanabe, K. \& Davis, R.A. (eds.): Ammonoid Paleobiology, 407-461. 
Plenum Press, New York.

363 Checa, A. 1987: Morphogenesis in ammonites-Differences linked to growth pattern. Lethaia 20, 141-148.

Chirat, R., Enay, R., Hantzpergue, P. \& Mangold, C. 2008: Developmental integration related to buoyancy control in nautiloids: evidence from unusual septal approximation and ontogenetic allometries in a Jurassic species. Palaeontology 51, 251-261.

Chirat, R. \& Rioult, M. 1998: Occurrence of early post-hatching Jurassic Nautilida in Normandy, France: Palaeobiologic, palaeoecologic and palaeobiogeographic implications. Lethaia 31, 137-148.

Choe, S. 1962: The shell and the locular index of the cuttlefishes, Sepia esculenta Hoyle, Sepia subaculeata Sasaki and Sepiella maindroni De Rochebrune. Bulletin of the Japanese Society of Scientific Fisheries 28, 1082-1091. (in Japanese with English abstract)

Chung, M.T. \& Wang, C.H. 2013: Age validation of the growth lamellae in the cuttlebone from cultured Sepia pharaonis at different stages. Journal of Experimental Marine Biology and Ecology 447, 132-137.

Collins, D. \& Ward, P.D. 1987: Adolescent growth and maturity in Nautilus. In Saunders, W.B. \& Landman, N.H. (eds.): Nautilus, 421-432. Plenum Press, New York. 
Denton, E.J. \& Gilpin-Brown, J.B. 1964: The buoyancy of the cuttlefish Sepia officinalis. Journal of the Marine Biological Association of the United Kingdom 41, 319-342.

Denton, E.J. \& Gilpin-Brown, J.B. 1971: Further observations on the buoyancy of Spirula spirula. Journal of the Marine Biological Association of the United Kingdom 51, 363-373.

Denton, E.J., Gilpin-Brown, J.B. \& Howarth, J.V. 1967: On the buoyancy of Spirula spirula. Journal of the Marine Biological Association of the United Kingdom 47, 181-191.

Dommergues, J.-L. 1988: Can ribs and septa provide an alternate standard for age in ammonite ontogenetic studies? Lethaia 21, 243-256.

Doguzhaeva, L. 1982: Rhythms of ammonoid shell secretion. Lethaia 15, 385-394. 
Ebbighausen, V. \& Korn, D. 2007: Conch geometry and ontogenetic trajectories in the triangularly coiled Late Devonian ammonoid Wocklumeria and related genera. Neues Jahrbuch für Geologie und Paläontologie, Abhandlungen 244, 9-41.

Ehrenberg, C.G. 1828-1831: Symbolae physicae, seu icones et descriptiones Mammalium, Avium, Insectorum et animalia evertebra, quae ex itinere per Africam borealem et Asiam occidentalem studio nova aut illustrata redierunt. Animalia evertebrata. $126 \mathrm{pp}$.

Gray, J.E. 1849: Catalogue of the Mollusca in the British Museum. Part I. Cephalopoda Antepedia, 164 pp. British Museum, London.

Hewitt, R. \& Stait, B. 1988: Seasonal variation in septal spacing of Sepia officinalis and some Ordovician actinocerid nautiloids. Lethaia 21, 383-394.

Hoyle, W.E. 1885: Diagnosis of new species of Cephalopoda collected during the cruise of H.M.S. “Challenger”-II: The Decapoda. Annals and Magazine of Natural History (Series 5) 16, 181-203.

Iwasaki, T., Iwasaki, Y. \& Wani, R. 2020: Polymorphism in Late Cretaceous phylloceratid ammonoids: evidence from ontogenetic trajectories of septal spacing. Papers in Palaeontology 6, in press.

Klug, C. 2004: Mature modifications, the black band, the black aperture, the black stripe, and the periostracum in cephalopods from the Upper Muschelkalk (Middle Triassic, Germany). Mitteilungen aus dem Geologisch-Paläontologischen Institut der Universität Hamburg 
$88,63-78$.

420 Klug, C., Meyer, E.P., Richter, U. \& Korn, D. 2008: Soft-tissue imprints in fossil and Recent cephalopod septa and septum formation. Lethaia 41, 477-492

Korn, D. \& Titus, A. 2006: The ammonoids from the Three Forks Shale (Late Devonian) of Montana. Fossil Record 9, 198-212.

Kraft, S., Korn, D. \& Klug, C. 2008: Ontogenetic patterns of septal spacing in Carboniferous ammonoids. Neues Jahrbuch für Geologie und Mineralogie, Abhandlungen 250, 31-44.

Kulicki, C. 1974: Remarks on the embryogeny and postembryonal development of ammonites. Acta Palaeontologica Polonica 19, 201-224.

Landman, N.H. 1987: Ontogeny of Upper Cretaceous (Turonian-Santonian) scaphitid ammonites from the Western Interior of North America: Systematics, developmental patterns and life history. Bulletin of American Museum of National History 185, 118-241.

Landman, N.H. 1988: Early ontogeny of Mesozoic ammonites and nautilids. In Wiedmann, J. \& Kullmann, J. (eds.): Cephalopods, Present and Past, 215-228. Schweizerbart'sche Verlagsbuchhandlung, Stuttgart.

Landman, N.H., Rye, D.M. \& Shelton, K.L. 1983: Early ontogeny of Eutrephoceras compared to Recent Nautilus and Mesozoic ammonites: evidence from shell morphology and light stable isotopes. Paleobiology 9, 269-279.

Landman, N.H., Tanabe, K. \& Shigeta, Y. 1996: Ammonoid embryonic development. In Landman, 
N.H., Tanabe K. \& Davis, R.A. (eds.): Ammonoid Paleobiology, 343-405. Plenum Press,

New York.

Lemanis, R., Zachow, S., Fusseis, F. \& Hoffmann, R. 2015: A new approach using high-resolution computed tomography to test the buoyant properties of chambered cephalopod shells. Paleobiology 41, 313-329.

Lemanis, R., Korn, D., Zachow, S., Rybacki, E. \& Hoffmann, R. 2016: The evolution and development of cephalopod chambers and their shape. PLoS ONE 11(3): e0151404. doi:10.1371/journal.pone.0151404

Lindgren, A.R., Pankey, M.S., Hochberg, F.G. \& Oakley, T.H. 2012: A multi-gene phylogeny of Cephalopoda supports convergent morphological evolution in association with multiple habitat shifts in the marine environment. BMC Evolutional Biology 12, 129

Lü, Z., Cui, W., Liu, L., Pang, Z. \& Zhang, Y. 2019: The complete mitochondrial genome of Sepia latimanus (Sepiidae, Sepioidea) and its phylogenetic implications. Mitochondrial DNA Part B 4, 1002-1003.

Martínez, P., Bettencourt, V., Guerra, Á. \& Moltschaniwskyj, N. 2000: How temperature influences muscle and cuttlebone growth in juvenile cuttlefish (Sepia elliptica) (Mollusca: Cephalopoda) under conditions of food stress. Canadian Journal of Zoology $78,1855-1861$.

Nabhitabhata, J. \& Nilaphat, P. 1999: Life cycle of cultured pharaoh cuttlefish, Sepia phraonis 
Ehrenberg, 1831. Phuket Marine Biological Center, Special Publication 19, 25-40.

458 Naglik, C., Monnet, C., Goetz, S., Kolb, C., De Baets, K., Tajika, A. \& Klug, C. 2015: Growth trajectories of some major ammonoid sub-clades revealed by serial grinding tomography data. Lethaia 48, 29-46.

Okamoto, T. \& Shibata, M. 1997: A cyclic mode of shell growth and its implications in a Late Cretaceous heteromorphy ammonite Polyptychoceras pseudogaultinum (Yokoyama). Paleontological Research 1, 29-46.

Okutani, T. 1978: Studies on early life history of Decapodan Mollusca_VII: Eggs and newly hatched larvae of Sepia latimanus Quoy \& Gaimard. Venus (Japanese Journal of Malacology) 37, 245-248.

Okutani, T. 1979a: Biology of Cephalopoda-3. Systematics and life history of the Sepioidea (2). Aquabiology 1, 37-42. (in Japanese with English abstract)

Okutani, T. 1979b: Biology of Cephalopoda-4. Systematics and life history of the Sepioidea (3). Aquabiology 1, 65-71. (in Japanese with English abstract)

Quoy, J.R.C. \& Gaimard, J.P. 1832-1835: Voyage de découvertes de l'Astrolabe exécuté par ordre du Roi, pendant les années 1826-1829, sous le commandement de M. J. Dumont d'Urville. Zoologie. Paris: Tastu. p. 1-321 [1832], 321-686 [1833], 1-366 [1834], 367-954 [1835].

Ruzhencev, V.E. \& Shimansky, V.E. 1954: Lower Permian coiled and curved nautiloids of the 
southern Urals. Transactions of the Paleontological Institute 50, 1-152 (In Russian).

Sanchez, G., Tomano, S., Umino, T., Wakabayashi, T., Sakai, M. 2016: Evaluation of the 5' end of the 16S rRNA gene as a DNA barcode marker for the Cephalopoda. Fisheries Science 82, 279-288.

Sasaki, M. 1929: A monograph of the dibranchiate cephalopods of the Japanese and adjacent waters. Journal of the Faculty of Agriculture, Hokkaido Imperial University 20, 1-357.

Tajika, A., Morimoto, N., Wani, R. \& Klug, C. 2018: Intraspecific variation in cephalopod conchs changes during ontogeny: perspectives from three-dimensional morphometry of Nautilus pompilius. Paleobiology 44, 118-130.

Tajika, A., Morimoto, N., Wani, R., Naglik, C. \& Klug, C. 2015: Intraspecific variation of phragmocone chamber volumes throughout ontogeny in the modern nautilid Nautilus and the Jurassic ammonite Normannites. PeerJ 3:e1306; DOI 10.7717/peerj.1306

Tajika, A., Naglik, C., Morimoto, N., Pascual-Cebrian, E., Hennhöfer, D. \& Klug, C. 2014: Empirical 3D model of the conch of the Middle Jurassic ammonite microconch Normannites: its buoyancy, the physical effects of its mature modifications and speculations of their function. Historical Biology 27, 181-191.

Tanabe, K. \& Tsukahara, J. 1987: Biometric analysis of Nautilus pompilius from the Philippines and the Fiji Islands. In Saunders, W.B. \& Landman, N.H. (eds.): Nautilus, 105-113. Plenum Press, New York. 
495 Wani, R. \& Ayyasami, K. 2009: Ontogenetic change and intraspecific variation of shell

morphology in the Cretaceous nautiloid (Cephalopoda, Mollusca) Eutrephoceras

clementinum (d'Orbigny, 1840) from the Ariyalur area, southern India. Journal of

Paleontology 83, 365-378.

Wani, R. \& Mapes, R.H. 2010: Conservative evolution in nautiloid shell morphology: evidence from the Pennsylvanian nautiloid Metacoceras mcchesneyi from Ohio, USA. Journal of Paleontology 84, 477-492.

Wani, R., Tajika, A., Ikuno, K. \& Iwasaki, T. 2018: Ontogenetic trajectories of septal spacing of Early Jurassic belemnites from Germany and France and their palaeobiological implications. Palaeontology 61, 77-88.

Yamaguchi, A., Kumada, Y., Alfaro, A.C. \& Wani, R. 2015: Abrupt changes in distance between succeeding septa at the hatching time in modern coleoids Sepiella japonica and Spirula spirula. Swiss Journal of Palaeontology 134, 301-307.

Yoshida, M., Tsuneki, K. \& Furuya, H. 2006: Phylogeny of selected Sepiidae (Mollusca, Cephalopoda) based on $12 \mathrm{~S}, 16 \mathrm{~S}$, and COI Sequences, with comments on the taxonomic reliability of several morphological characters. Zoological Science 23, 341-351.

Yoshida, M., Tsuneki, K. \& Furuya, H. 2010: Molecular phylogeny among East-Asian cuttlefishes using three mitochondrial genes. In Tanabe, K., Shigeta, Y., Sasaki, T. \& Hirano, H. (eds.): Cephalopods - Present and Past, 15-21. Tokai University Press, Tokyo. 
515 Figure captions (figure widths; single column, Fig. 1; full page width, Figs. 2-8)

Fig. 1. Map of the examined specimens in the studied locations.

Fig. 2. Supposed phylogeny of the five examined species based on DNA molecular analyses. A, Bonnaud et al. (2006); B, Yoshida et al. (2006); C, Yoshida et al. (2010); D, Anderson et al. (2011); E, Lindgren et al. (2012); F, Dai et al. (2012); G, Sanchez et al. (2016). All phylogenetic trees are simplified from the originals, showing the relationship among only the five examined species.

Fig. 3. Measurements of septal spacing and shell morphology. A, schematic diagram of the cross section of cuttlebone. Modified from Yamaguchi et al. (2015). B, five parameters representing the shape of the cuttlebone. Wo, shell width; Wi, shell width without outer cone; Lo, shell length; Li, shell length without outer cone; T, shell thickness.

Fig. 4. Graphs of septal spacing through ontogeny of Sepia esculenta from two localities. A, all specimens; B, average ontogenetic trajectories of septal spacing with error bars (standard deviations $[\mathrm{SD}])$.

Fig. 5. Graphs of septal spacing through ontogeny for the examined modern cuttlefishes. A, B, Sepia esculenta; C, D, Sepia lycidas; E, F, Sepia latimanus. A, C, E, all specimens; B, D, F, average ontogenetic trajectories of septal spacing with error bars (standard deviations).

Fig. 6. Graphs of septal spacing through ontogeny for the examined modern cuttlefishes. A, B, 
Sepia pharaonis; C, D, Sepiella japonica. A, C, all specimens; B, D, average ontogenetic trajectories of septal spacing with error bars (standard deviations).

Fig. 7. Results of cluster analyses. A, cluster analysis with the average septal trajectories of the five examined species by Ward's method. B, cluster analysis with the septal spacing of all the examined specimens by Ward's method. C, simplified result of B. width (Wo) vs. shell length (Lo); D, shell width without outer cone (Wi) vs. shell length without outer cone (Li); E, shell length (Lo) vs. shell length without outer cone (Li). 


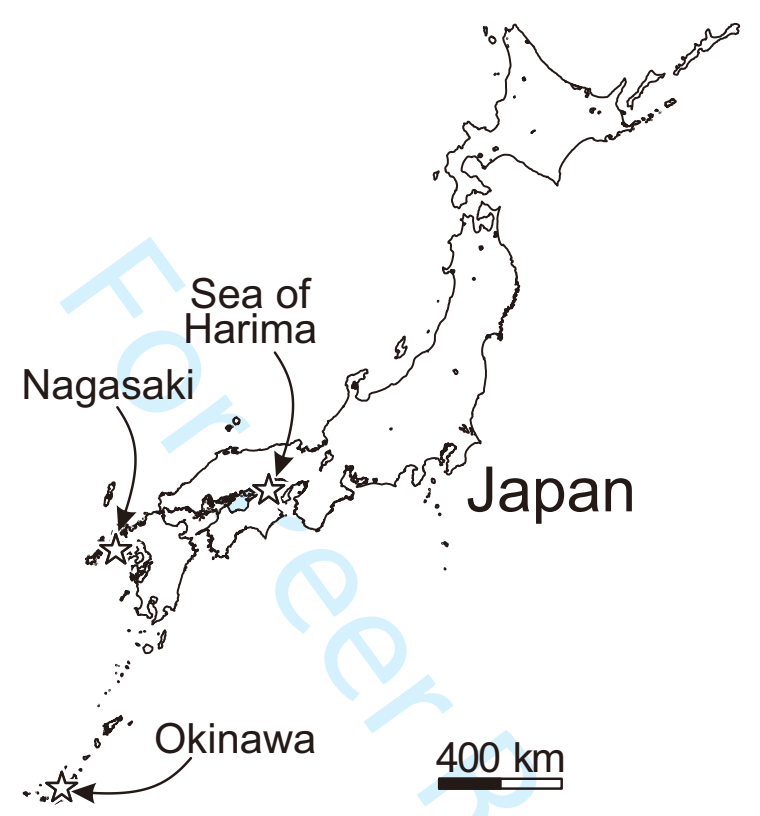


A

Bonnaud et al. (2006)
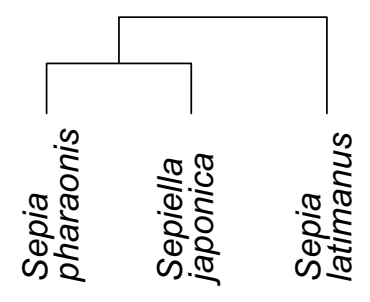

C Yoshida et al. (2010)

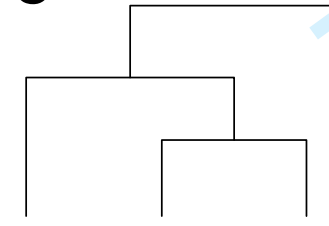

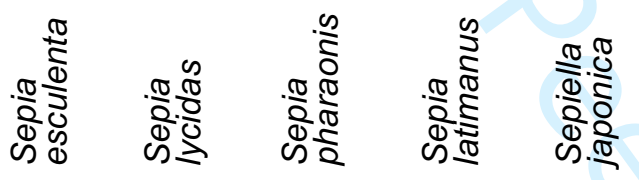

$\mathrm{E} \quad$ Lindgren et al. (2012)

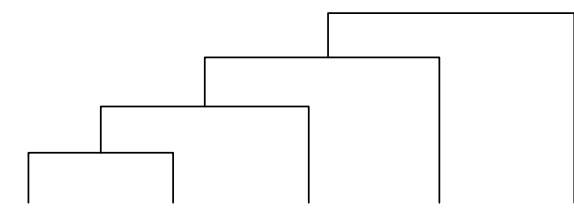

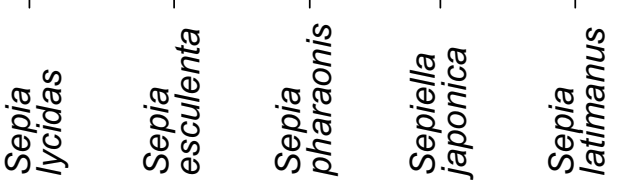

G Sanchez et al. (2016)

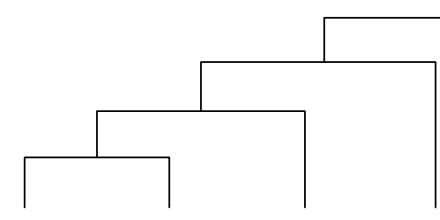

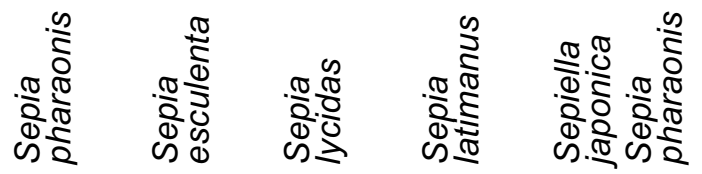

F

Dai et al. (2012)
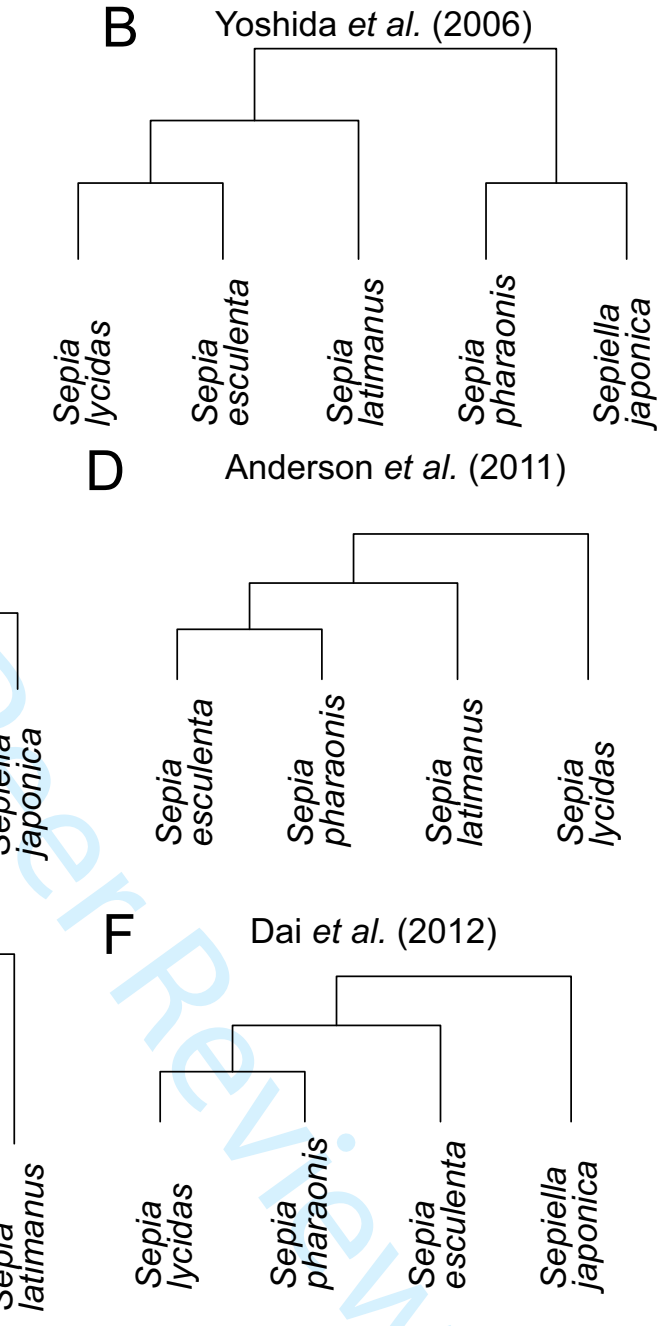

D Anderson et al. (2011)
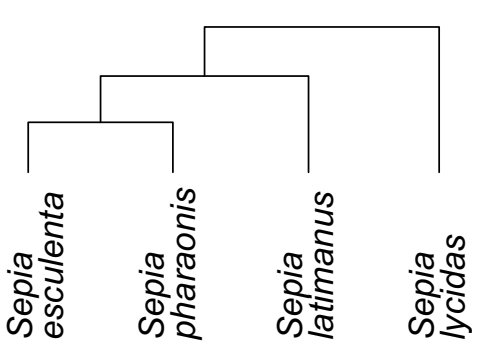

42 

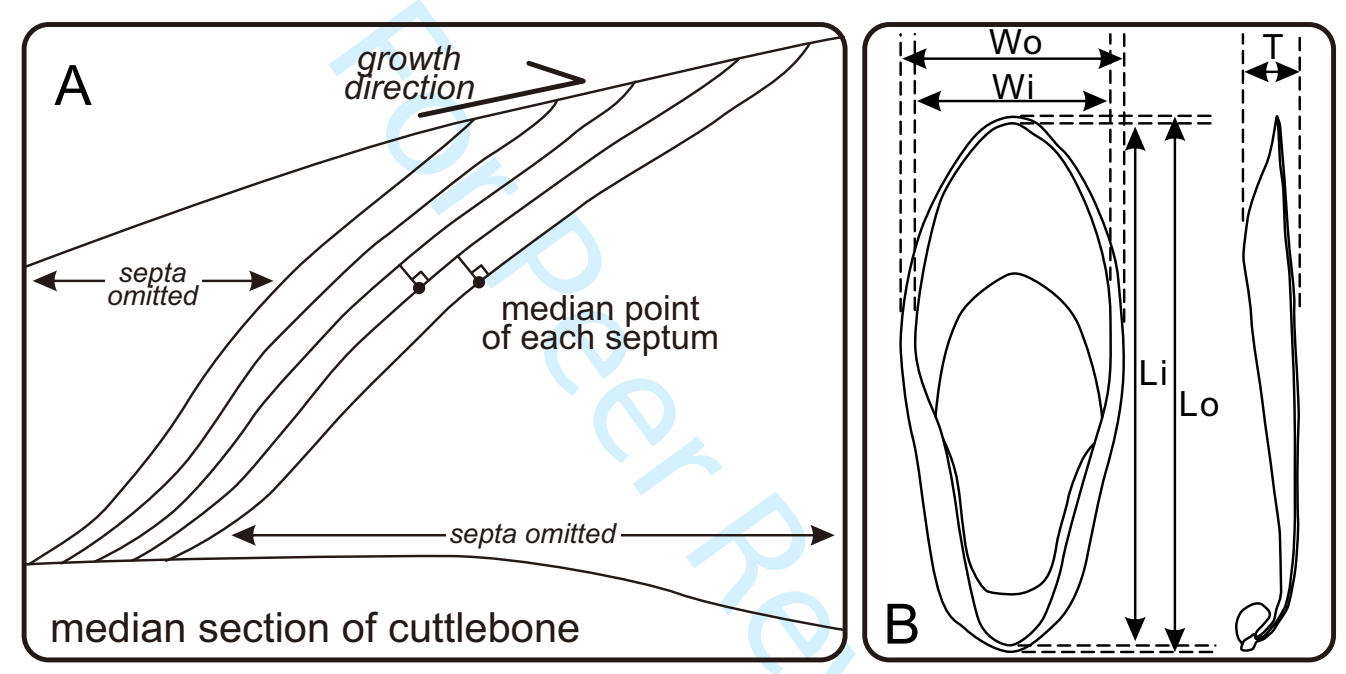

36

37

38

39

40

41

42

43 
Page 33 of 83

Lethaia

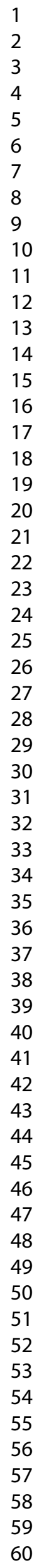

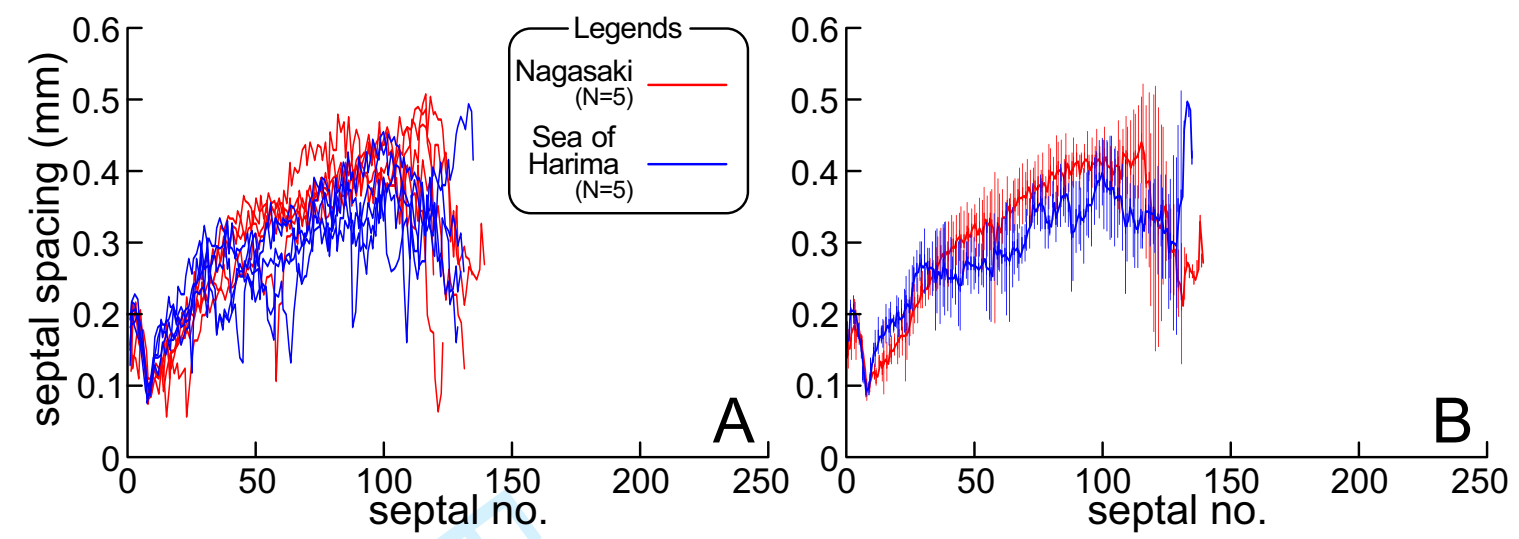

Lethaia - manuscript copy 

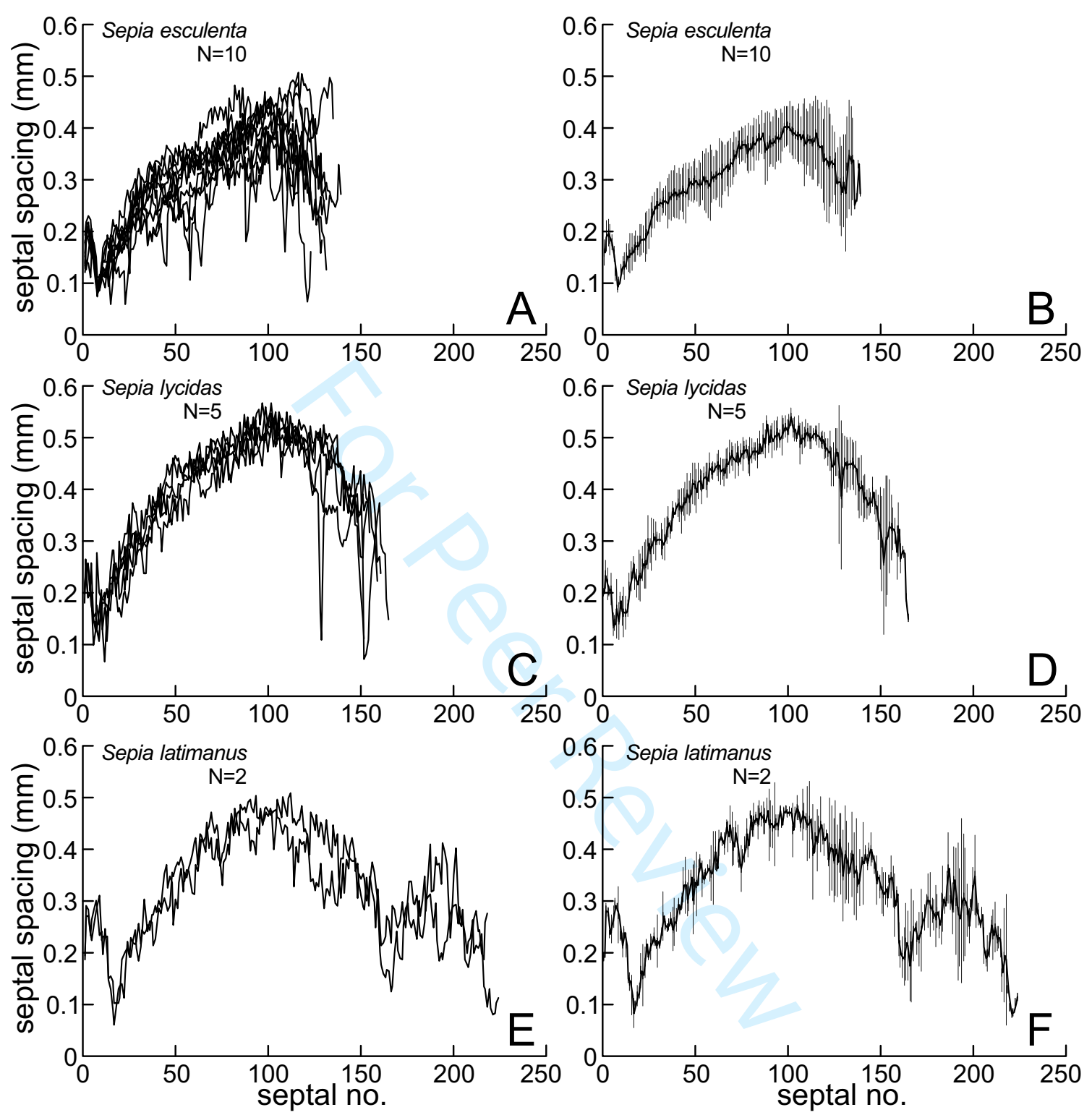

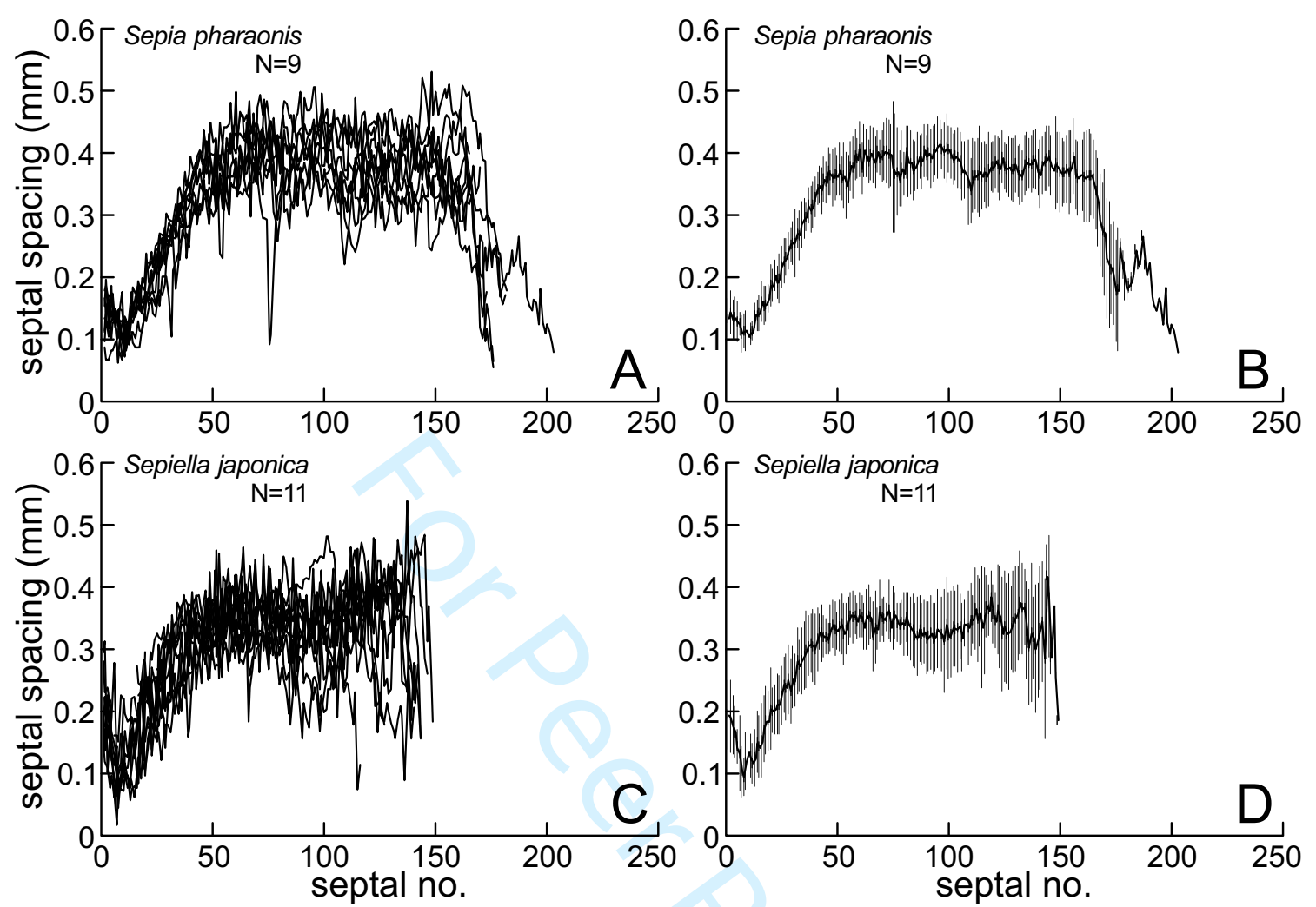

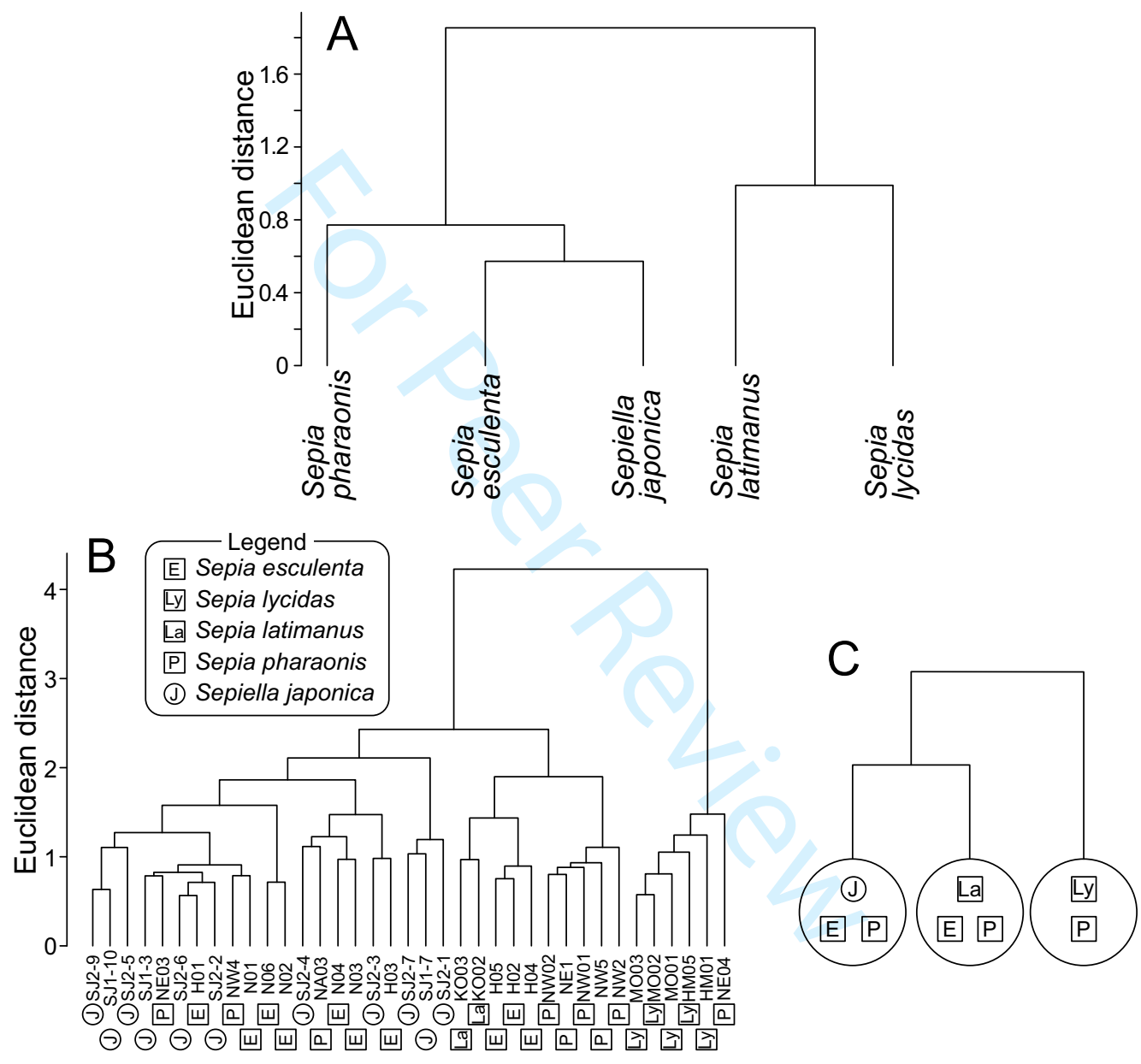

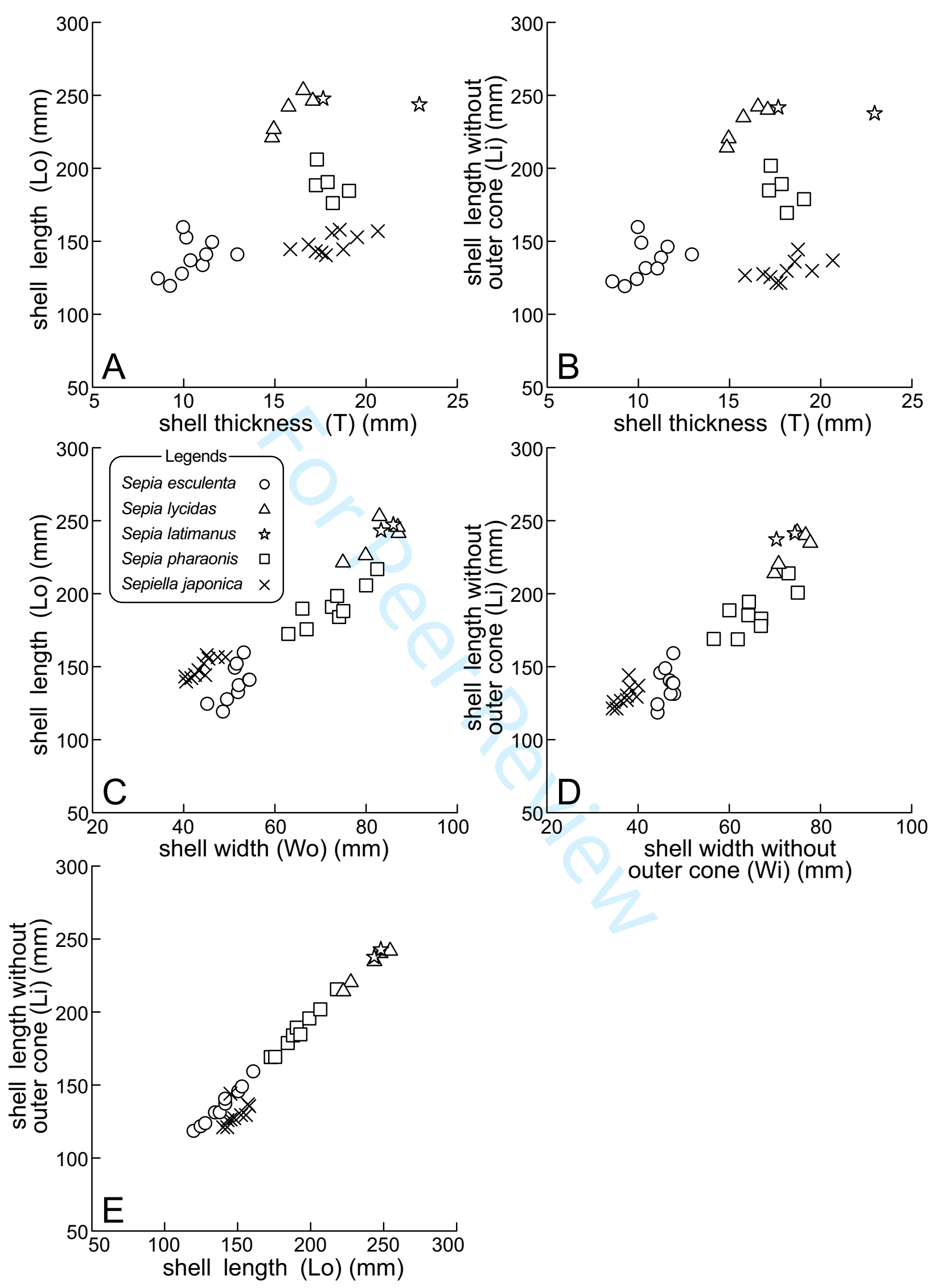

outer cone (Wi) (mm) 


\begin{tabular}{|c|c|c|c|c|c|}
\hline species & locality & sample no. & $\begin{array}{c}\text { repository } \\
\text { no. }\end{array}$ & sex & maturity \\
\hline \multirow{10}{*}{$\begin{array}{c}\text { Sepia } \\
\text { esculenta }\end{array}$} & \multirow{5}{*}{ Nagasaki } & N01 & MCM.W.1519 & female & mature \\
\hline & & N02 & MCM.W.1520 & female & mature \\
\hline & & N03 & MCM.W.1521 & female & mature \\
\hline & & N04 & MCM.W.1522 & female & mature \\
\hline & & N06 & MCM.W.1523 & female & mature \\
\hline & \multirow{5}{*}{$\begin{array}{l}\text { Sea of } \\
\text { Harima }\end{array}$} & $\mathrm{H} 01$ & MCM.W.1524 & female & mature \\
\hline & & $\mathrm{H} 02$ & MCM.W.1525 & male & mature \\
\hline & & $\mathrm{H} 03$ & MCM.W.1526 & male & mature \\
\hline & & $\mathrm{H} 04$ & MCM.W.1527 & male & mature \\
\hline & & $\mathrm{H} 05$ & MCM.W.1528 & - & mature \\
\hline \multirow{5}{*}{ Sepia lycidas } & \multirow{5}{*}{$\begin{array}{l}\text { Sea of } \\
\text { Harima }\end{array}$} & MO01 & MCM.W.1529 & male & mature \\
\hline & & MO02 & MCM.W.1530 & male & mature \\
\hline & & MO03 & MCM.W.1531 & male & mature \\
\hline & & HM01 & MCM.W.1532 & male & mature \\
\hline & & HM05 & MCM.W.1533 & female & mature \\
\hline \multirow{2}{*}{$\begin{array}{c}\text { Sepia } \\
\text { latimanus }\end{array}$} & \multirow{2}{*}{ Okinawa } & KO02 & MCM.W.1534 & male & mature \\
\hline & & $\mathrm{KO} 03$ & MCM.W.1535 & female & mature \\
\hline \multirow{9}{*}{$\begin{array}{c}\text { Sepia } \\
\text { pharaonis }\end{array}$} & \multirow{9}{*}{ Okinawa } & NE1 & MCM.W.1536 & - & - \\
\hline & & NW01 & MCM.W.1537 & - & - \\
\hline & & NW2 & MCM.W.1538 & - & - \\
\hline & & NW5 & MCM.W.1539 & - & - \\
\hline & & NW4 & MCM.W.1540 & - & - \\
\hline & & NA03 & MCM.W.1541 & male & mature \\
\hline & & NE03 & MCM.W.1542 & - & - \\
\hline & & NE04 & MCM.W.1543 & - & - \\
\hline & & NW02 & MCM.W.1544 & female & mature \\
\hline \multirow{11}{*}{$\begin{array}{l}\text { Sepiella } \\
\text { japonica }\end{array}$} & \multirow{11}{*}{$\begin{array}{l}\text { Sea of } \\
\text { Harima }\end{array}$} & SJ1-3 & MCM.A.1741 & - & - \\
\hline & & SJ1-7 & MCM.A.1742 & - & - \\
\hline & & SJ1-10 & MCM.A.1743 & - & - \\
\hline & & SJ2-1 & MCM.A.1744 & - & - \\
\hline & & SJ2-2 & MCM.A.1745 & - & - \\
\hline & & SJ2-3 & MCM.A.1746 & - & - \\
\hline & & SJ2-4 & MCM.A.1747 & female & mature \\
\hline & & SJ2-5 & MCM.A.1748 & female & mature \\
\hline & & SJ2-6 & MCM.A.1749 & female & mature \\
\hline & & SJ2-7 & MCM.A.1750 & female & mature \\
\hline & & SJ2-9 & MCM.A.1751 & female & mature \\
\hline
\end{tabular}




\begin{tabular}{|c|c|c|c|}
\hline $\begin{array}{l}\text { mantle length } \\
\qquad(\mathrm{mm})\end{array}$ & $\begin{array}{c}\text { numbers of } \\
\text { septa }\end{array}$ & $\begin{array}{l}\text { shell length } \\
\text { (Lo) (mm) }\end{array}$ & $\begin{array}{c}\text { shell length } \\
\text { without outer cone } \\
\text { (Li) }(\mathrm{mm})\end{array}$ \\
\hline- & 131 & 134.5 & 133.0 \\
\hline 130 & 130 & 120.1 & 120.1 \\
\hline 150 & 145 & 138.0 & 132.8 \\
\hline 138 & 120 & 128.2 & 125.6 \\
\hline 130 & 129 & 125.2 & 123.4 \\
\hline 144 & 139 & 141.8 & 139.7 \\
\hline 145 & 140 & 142.0 & 142.0 \\
\hline 170 & 123 & 160.7 & 160.0 \\
\hline 159 & 131 & 150.6 & 147.3 \\
\hline 155 & 134 & 152.9 & 150.5 \\
\hline 241 & 159 & 228.0 & 222.0 \\
\hline 255 & 155 & 248.0 & 242.2 \\
\hline 278 & 161 & 255.0 & 244.0 \\
\hline 234 & 152 & 223.0 & 216.2 \\
\hline 246 & 165 & 244.0 & 236.3 \\
\hline 256 & 224 & 244.2 & 237.7 \\
\hline 257 & 218 & 248.0 & 241.7 \\
\hline- & 165 & 176.0 & 170.2 \\
\hline- & 176 & 188.0 & 184.4 \\
\hline- & 176 & 206.0 & 201.3 \\
\hline- & 170 & 190.0 & 188.8 \\
\hline- & 182 & 184.0 & 179.3 \\
\hline 207 & 203 & 191.6 & 186.5 \\
\hline- & 166 & 172.6 & 169.4 \\
\hline- & 181 & 217.3 & 215.4 \\
\hline 205 & 173 & 198.4 & 195.4 \\
\hline- & 137 & 140.5 & 122.0 \\
\hline- & 147 & 157.5 & 138.0 \\
\hline- & 136 & 147.6 & 128.7 \\
\hline- & 137 & 156.0 & 130.5 \\
\hline- & 140 & 157.4 & 137.5 \\
\hline- & 143 & 152.7 & 130.4 \\
\hline- & 116 & 145.3 & 127.0 \\
\hline- & 143 & 158.0 & 136.7 \\
\hline- & 141 & 145.1 & 144.5 \\
\hline- & 149 & 143.8 & 126.2 \\
\hline- & 142 & 143.1 & 122.2 \\
\hline
\end{tabular}




\begin{tabular}{|c|c|c|}
\hline $\begin{array}{l}\text { shell width } \\
\text { (Wo) (mm) }\end{array}$ & $\begin{array}{c}\text { shell width } \\
\text { without outer cone } \\
\text { (Wi) }(\mathrm{mm})\end{array}$ & $\begin{array}{l}\text { shell thickness } \\
\text { (T) }(\mathrm{mm})\end{array}$ \\
\hline 52.0 & 48.0 & 11.1 \\
\hline 48.6 & 44.4 & 9.2 \\
\hline 52.0 & 47.2 & 10.4 \\
\hline 49.5 & 44.3 & 9.9 \\
\hline 45.2 & 41.6 & 8.6 \\
\hline 54.6 & 47.7 & 11.2 \\
\hline 54.0 & 47.0 & 13.0 \\
\hline 53.1 & 47.9 & 10.0 \\
\hline 51.2 & 45.1 & 11.6 \\
\hline 51.7 & 46.1 & 10.1 \\
\hline 80.0 & 71.0 & 15.0 \\
\hline 87.0 & 77.0 & 17.1 \\
\hline 83.0 & 75.0 & 16.6 \\
\hline 75.0 & 70.0 & 14.8 \\
\hline 87.2 & 77.9 & 15.7 \\
\hline 83.3 & 70.4 & 22.9 \\
\hline 85.8 & 74.4 & 17.7 \\
\hline 67.0 & 62.0 & 18.2 \\
\hline 75.0 & 67.0 & 17.3 \\
\hline 80.0 & 75.0 & 17.3 \\
\hline 66.0 & 60.0 & 17.9 \\
\hline 74.0 & 67.0 & 19.1 \\
\hline 72.5 & 64.3 & - \\
\hline 63.0 & 56.6 & - \\
\hline 82.4 & 72.9 & - \\
\hline 73.7 & 64.2 & - \\
\hline 40.6 & 34.6 & 17.8 \\
\hline 49.3 & 41.8 & - \\
\hline 43.3 & 37.8 & 16.8 \\
\hline 45.4 & 39.9 & 18.1 \\
\hline 47.4 & 40.3 & 20.6 \\
\hline 44.4 & 37.8 & 19.5 \\
\hline 42.5 & 36.4 & 15.8 \\
\hline 45.2 & 38.2 & 18.5 \\
\hline 44.8 & 38.1 & 18.7 \\
\hline 40.3 & 34.8 & 17.2 \\
\hline 41.7 & 35.4 & 17.6 \\
\hline
\end{tabular}


septal spacing (mm)

Septal no.

1

2

3

4

5

6

7

8

9

10

11

12

13

14

15

16

17

18

19

20

21

22

23

24

25

26

27

28

29

30

31

32

33

34

35

36

37

38

39

40

41

42

43

44

45

46
H01

Nagasaki

0.18

0.13

0.16

0.20

0.19

0.15

0.13

0.09

0.12

0.11

0.11

0.09

0.13

0.14

0.19

0.11

0.15

0.15

0.16

0.16

0.17

0.17

0.18

0.17

0.19

0.20

0.22

0.21

0.25

0.22

0.22

0.26

0.24

0.27

0.26

0.28

0.31

0.31

0.30

0.30

0.33

0.32

0.31

0.34

0.32

0.31
$\mathrm{HO2}$

Nagasaki

0.14

0.18

0.22

0.16

0.15

0.15

0.10

0.08

0.11

0.13

0.13

0.13

0.14

0.13

0.06

0.11

0.15

0.12

0.13

0.11

0.12

0.13

0.06

0.11

0.15

0.17

0.17

0.18

0.20

0.20

0.22

0.21

0.22

0.22

0.23

0.24

0.23

0.22

0.24

0.24

0.24

0.25

0.26

0.26

0.26

0.25
$\mathrm{H} 03$

Nagasak

0.14

0.21

0.20

0.17

0.21

0.16

0.13

0.10

0.09

0.13

0.12

0.12

0.12

0.10

0.12

0.15

0.15

0.15

0.17

0.17

0.21

0.17

0.20

0.21

0.22

0.26

0.24

0.26

0.25

0.28

0.28

0.26

0.29

0.28

0.29

0.33

0.32

0.33

0.34

0.34

0.34

0.33

0.35

0.34

0.37

0.36
$\mathrm{H} 04$

Nagasaki Nagasaki

0.12

0.15

0.14

0.11

0.17

0.14

0.11

0.08

0.09

0.11

0.12

0.11

0.14

0.12

0.16

0.13

0.13

0.15

0.17

0.17

0.17

0.19

0.18

0.21

0.20

0.20

0.22

0.21

0.22

0.23

0.25

0.25

0.25

0.26

0.30

0.28

0.29

0.28

0.30

0.31

0.32

0.30

0.32

0.31

0.32

0.30

0.18

0.20

0.21

0.20

0.18

0.18

0.15

0.11

0.11

0.13

0.12

0.12

0.13

0.15

0.17

0.18

0.17

0.16

0.20

0.19

0.20

0.23

0.20

0.22

0.21

0.23

0.24

0.22

0.23

0.22

0.25

0.25

0.24

0.24

0.24

0.27

0.26

0.25

0.23

0.25

0.28

0.28

0.29

0.26

0.15 


\begin{tabular}{|c|c|c|c|c|c|}
\hline 47 & 0.35 & 0.28 & 0.36 & 0.32 & 0.26 \\
\hline 48 & 0.32 & 0.28 & 0.35 & 0.33 & 0.27 \\
\hline 49 & 0.35 & 0.31 & 0.33 & 0.33 & 0.27 \\
\hline 50 & 0.34 & 0.32 & 0.36 & 0.33 & 0.29 \\
\hline 51 & 0.33 & 0.29 & 0.35 & 0.31 & 0.27 \\
\hline 52 & 0.37 & 0.31 & 0.35 & 0.32 & 0.26 \\
\hline 53 & 0.34 & 0.31 & 0.36 & 0.32 & 0.23 \\
\hline 54 & 0.35 & 0.34 & 0.36 & 0.36 & 0.26 \\
\hline 55 & 0.34 & 0.32 & 0.37 & 0.33 & 0.26 \\
\hline 56 & 0.35 & 0.34 & 0.36 & 0.35 & 0.26 \\
\hline 57 & 0.35 & 0.33 & 0.36 & 0.34 & 0.23 \\
\hline 58 & 0.33 & 0.32 & 0.35 & 0.36 & 0.11 \\
\hline 59 & 0.36 & 0.35 & 0.37 & 0.35 & 0.22 \\
\hline 60 & 0.36 & 0.32 & 0.34 & 0.33 & 0.22 \\
\hline 61 & 0.35 & 0.33 & 0.37 & 0.35 & 0.27 \\
\hline 62 & 0.35 & 0.34 & 0.36 & 0.32 & 0.31 \\
\hline 63 & 0.34 & 0.32 & 0.41 & 0.37 & 0.31 \\
\hline 64 & 0.35 & 0.34 & 0.38 & 0.33 & 0.32 \\
\hline 65 & 0.35 & 0.34 & 0.41 & 0.33 & 0.31 \\
\hline 66 & 0.36 & 0.35 & 0.40 & 0.35 & 0.30 \\
\hline 67 & 0.35 & 0.37 & 0.40 & 0.35 & 0.35 \\
\hline 68 & 0.33 & 0.35 & 0.43 & 0.36 & 0.33 \\
\hline 69 & 0.36 & 0.35 & 0.44 & 0.35 & 0.34 \\
\hline 70 & 0.34 & 0.37 & 0.41 & 0.37 & 0.32 \\
\hline 71 & 0.36 & 0.36 & 0.44 & 0.38 & 0.34 \\
\hline 72 & 0.33 & 0.35 & 0.43 & 0.36 & 0.35 \\
\hline 73 & 0.37 & 0.39 & 0.42 & 0.37 & 0.36 \\
\hline 74 & 0.37 & 0.36 & 0.44 & 0.37 & 0.34 \\
\hline 75 & 0.38 & 0.38 & 0.44 & 0.39 & 0.33 \\
\hline 76 & 0.38 & 0.36 & 0.42 & 0.37 & 0.36 \\
\hline 77 & 0.38 & 0.36 & 0.44 & 0.40 & 0.34 \\
\hline 78 & 0.37 & 0.38 & 0.40 & 0.38 & 0.34 \\
\hline 79 & 0.41 & 0.35 & 0.46 & 0.39 & 0.35 \\
\hline 80 & 0.43 & 0.35 & 0.43 & 0.39 & 0.39 \\
\hline 81 & 0.39 & 0.37 & 0.43 & 0.40 & 0.36 \\
\hline 82 & 0.38 & 0.40 & 0.48 & 0.38 & 0.35 \\
\hline 83 & 0.37 & 0.42 & 0.46 & 0.41 & 0.37 \\
\hline 84 & 0.35 & 0.40 & 0.47 & 0.39 & 0.37 \\
\hline 85 & 0.37 & 0.38 & 0.42 & 0.42 & 0.37 \\
\hline 86 & 0.39 & 0.42 & 0.48 & 0.40 & 0.38 \\
\hline 87 & 0.35 & 0.39 & 0.42 & 0.42 & 0.40 \\
\hline 88 & 0.40 & 0.40 & 0.44 & 0.40 & 0.38 \\
\hline 89 & 0.37 & 0.39 & 0.46 & 0.42 & 0.41 \\
\hline 90 & 0.40 & 0.41 & 0.45 & 0.42 & 0.39 \\
\hline 91 & 0.38 & 0.41 & 0.37 & 0.42 & 0.41 \\
\hline 92 & 0.40 & 0.40 & 0.40 & 0.43 & 0.42 \\
\hline 93 & 0.40 & 0.43 & 0.39 & 0.42 & 0.44 \\
\hline 94 & 0.39 & 0.43 & 0.36 & 0.44 & 0.45 \\
\hline 95 & 0.39 & 0.41 & 0.38 & 0.41 & 0.43 \\
\hline 96 & 0.40 & 0.43 & 0.36 & 0.44 & 0.43 \\
\hline 97 & 0.41 & 0.39 & 0.39 & 0.42 & 0.44 \\
\hline 98 & 0.38 & 0.40 & 0.38 & 0.47 & 0.45 \\
\hline
\end{tabular}




\begin{tabular}{|c|c|c|c|c|c|}
\hline 99 & 0.41 & 0.39 & 0.41 & 0.43 & 0.44 \\
\hline 100 & 0.40 & 0.39 & 0.37 & 0.45 & 0.44 \\
\hline 101 & 0.42 & 0.38 & 0.39 & 0.46 & 0.46 \\
\hline 102 & 0.39 & 0.38 & 0.38 & 0.46 & 0.43 \\
\hline 103 & 0.38 & 0.39 & 0.38 & 0.44 & 0.43 \\
\hline 104 & 0.38 & 0.42 & 0.38 & 0.41 & 0.39 \\
\hline 105 & 0.37 & 0.43 & 0.39 & 0.44 & 0.41 \\
\hline 106 & 0.36 & 0.44 & 0.33 & 0.48 & 0.43 \\
\hline 107 & 0.36 & 0.32 & 0.39 & 0.46 & 0.43 \\
\hline 108 & 0.38 & 0.42 & 0.42 & 0.45 & 0.46 \\
\hline 109 & 0.41 & 0.43 & 0.33 & 0.47 & 0.46 \\
\hline 110 & 0.39 & 0.44 & 0.35 & 0.46 & 0.44 \\
\hline 111 & 0.37 & 0.39 & 0.32 & 0.47 & 0.48 \\
\hline 112 & 0.37 & 0.43 & 0.32 & 0.49 & 0.47 \\
\hline 113 & 0.33 & 0.41 & 0.41 & 0.49 & 0.45 \\
\hline 114 & 0.37 & 0.46 & 0.35 & 0.49 & 0.47 \\
\hline 115 & 0.42 & 0.47 & 0.35 & 0.48 & 0.50 \\
\hline 116 & 0.39 & 0.46 & 0.27 & 0.49 & 0.51 \\
\hline 117 & 0.38 & 0.45 & 0.20 & 0.45 & 0.44 \\
\hline 118 & 0.39 & 0.51 & 0.18 & 0.44 & 0.42 \\
\hline 119 & 0.26 & 0.48 & 0.18 & 0.34 & 0.40 \\
\hline 120 & & 0.49 & 0.11 & 0.33 & 0.44 \\
\hline 121 & & 0.48 & 0.07 & 0.35 & 0.44 \\
\hline 122 & & 0.48 & 0.09 & 0.31 & 0.40 \\
\hline 123 & & 0.46 & 0.16 & 0.27 & 0.41 \\
\hline 124 & & 0.40 & & 0.22 & 0.43 \\
\hline 125 & & 0.39 & & 0.26 & 0.38 \\
\hline 126 & & 0.35 & & 0.25 & 0.31 \\
\hline 127 & & 0.28 & & 0.23 & 0.35 \\
\hline 128 & & 0.35 & & 0.23 & 0.29 \\
\hline 129 & & 0.28 & & 0.20 & 0.27 \\
\hline 130 & & 0.25 & & 0.19 & 0.28 \\
\hline 131 & & 0.22 & & 0.13 & 0.30 \\
\hline 132 & & 0.23 & & & 0.28 \\
\hline 133 & & 0.27 & & & 0.28 \\
\hline 134 & & 0.26 & & & \\
\hline 135 & & 0.26 & & & \\
\hline 136 & & 0.25 & & & \\
\hline 137 & & 0.26 & & & \\
\hline 138 & & 0.33 & & & \\
\hline 139 & & 0.27 & & & \\
\hline
\end{tabular}

140

141

142

143

144

145

146

147

148

149

150 
Lethaia

Page 44 of 83

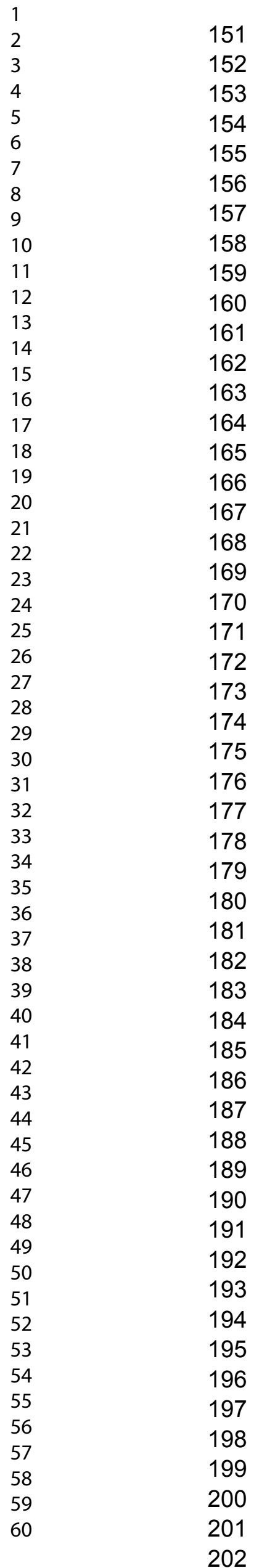

Lethaia - manuscript copy 
Sepia esculenta

N01
Sea of
Harima

0.15

0.20

0.21

0.20

0.17

0.13

0.10

0.09

0.09

0.13

0.17

0.18

0.19

0.17

0.19

0.19

0.20

0.22

0.19

0.20

0.21

0.20

0.19

0.20

0.21

0.24

0.24

0.26

0.26

0.27

0.29

0.24

0.28

0.28

0.26

0.27

0.27

0.30

0.33

0.30

0.29

0.28

0.29

0.25

0.25

0.27
N02

Sea of

Harima

0.19

0.19

0.19

0.20

0.17

0.16

0.12

0.11

0.09

0.12

0.13

0.12

0.14

0.16

0.17

0.19

0.18

0.17

0.18

0.19

0.19

0.20

0.21

0.21

0.24

0.24

0.24

0.27

0.30

0.27

0.27

0.27

0.25

0.24

0.18

0.20

0.19

0.21

0.20

0.19

0.20

0.24

0.27

0.26

0.26

0.28
N03

Sea of

Harima

0.13

0.22

0.22

0.20

0.18

0.15

0.12

0.08

0.10

0.13

0.14

0.17

0.18

0.18

0.18

0.16

0.15

0.21

0.19

0.20

0.18

0.19

0.20

0.21

0.12

0.19

0.28

0.25

0.29

0.23

0.31

0.27

0.27

0.29

0.30

0.29

0.30

0.31

0.33

0.29

0.33

0.28

0.29

0.29

0.30

0.30

\section{N04}

Sea of

Harima

0.20

0.22

0.23

0.22

0.19

0.18

0.12

0.10

0.10

0.13

0.15

0.15

0.20

0.19

0.19

0.23

0.21

0.21

0.20

0.24

0.23

0.23

0.26

0.28

0.26

0.28

0.29

0.30

0.29

0.32

0.30

0.31

0.30

0.30

0.32

0.34

0.32

0.32

0.27

0.28

0.21

0.22

0.18

0.14

0.13

0.23
N06

Sea of

Harima

0.16
0.20

0.19

0.17

0.17

0.16

0.13

0.10

0.10

0.14

0.14

0.14

0.14

0.16

0.14

0.16

0.17

0.17

0.17

0.19

0.16

0.17

0.18

0.19

0.22

0.23

0.23

0.23

0.24

0.24

0.20

0.24

0.23

0.21

0.17

0.20

0.18

0.20

0.20

0.21

0.23

0.24

0.25

0.27

0.26

0.25

average

(Nagasaki)

standard

deviation

(Nagasaki)

0.15

0.17

0.19

0.17

0.18

0.15

0.12

0.09

0.10

0.12

0.12

0.11

0.13

0.12

0.14

0.13

0.15

0.15

0.16

0.16

0.17

0.17

0.17

0.18

0.20

0.21

0.21

0.22

0.23

0.23

0.24

0.24

0.25

0.25

0.26

0.27

0.29 


\begin{tabular}{|c|c|c|c|c|c|c|}
\hline 0.29 & 0.26 & 0.32 & 0.26 & 0.25 & 0.31 & 0.042 \\
\hline 0.31 & 0.29 & 0.27 & 0.25 & 0.24 & 0.31 & 0.033 \\
\hline 0.32 & 0.31 & 0.26 & 0.22 & 0.25 & 0.32 & 0.030 \\
\hline 0.27 & 0.32 & 0.26 & 0.29 & 0.22 & 0.33 & 0.026 \\
\hline 0.30 & 0.28 & 0.27 & 0.27 & 0.23 & 0.31 & 0.030 \\
\hline 0.31 & 0.26 & 0.22 & 0.29 & 0.24 & 0.32 & 0.041 \\
\hline 0.30 & 0.24 & 0.28 & 0.29 & 0.24 & 0.31 & 0.049 \\
\hline 0.32 & 0.24 & 0.27 & 0.33 & 0.24 & 0.33 & 0.044 \\
\hline 0.33 & 0.21 & 0.27 & 0.33 & 0.20 & 0.32 & 0.043 \\
\hline 0.29 & 0.20 & 0.28 & 0.36 & 0.18 & 0.33 & 0.041 \\
\hline 0.33 & 0.21 & 0.27 & 0.31 & 0.17 & 0.32 & 0.052 \\
\hline 0.34 & 0.27 & 0.30 & 0.34 & 0.23 & 0.29 & 0.105 \\
\hline 0.33 & 0.27 & 0.28 & 0.32 & 0.23 & 0.33 & 0.062 \\
\hline 0.33 & 0.29 & 0.29 & 0.31 & 0.25 & 0.31 & 0.054 \\
\hline 0.33 & 0.26 & 0.27 & 0.34 & 0.21 & 0.34 & 0.038 \\
\hline 0.33 & 0.28 & 0.28 & 0.33 & 0.20 & 0.34 & 0.019 \\
\hline 0.33 & 0.29 & 0.27 & 0.35 & 0.15 & 0.35 & 0.041 \\
\hline 0.33 & 0.28 & 0.28 & 0.36 & 0.14 & 0.34 & 0.025 \\
\hline 0.31 & 0.28 & 0.32 & 0.35 & 0.20 & 0.35 & 0.037 \\
\hline 0.31 & 0.30 & 0.26 & 0.34 & 0.25 & 0.35 & 0.037 \\
\hline 0.34 & 0.29 & 0.26 & 0.32 & 0.27 & 0.36 & 0.025 \\
\hline 0.30 & 0.30 & 0.25 & 0.32 & 0.24 & 0.36 & 0.043 \\
\hline 0.31 & 0.30 & 0.31 & 0.31 & 0.25 & 0.37 & 0.041 \\
\hline 0.31 & 0.31 & 0.31 & 0.32 & 0.26 & 0.36 & 0.035 \\
\hline 0.32 & 0.30 & 0.36 & 0.33 & 0.28 & 0.38 & 0.039 \\
\hline 0.36 & 0.32 & 0.37 & 0.29 & 0.30 & 0.36 & 0.038 \\
\hline 0.36 & 0.36 & 0.39 & 0.34 & 0.32 & 0.38 & 0.024 \\
\hline 0.36 & 0.33 & 0.38 & 0.34 & 0.32 & 0.38 & 0.038 \\
\hline 0.39 & 0.36 & 0.37 & 0.33 & 0.33 & 0.38 & 0.038 \\
\hline 0.39 & 0.36 & 0.40 & 0.34 & 0.30 & 0.38 & 0.022 \\
\hline 0.36 & 0.37 & 0.39 & 0.32 & 0.32 & 0.38 & 0.040 \\
\hline 0.29 & 0.36 & 0.38 & 0.33 & 0.29 & 0.37 & 0.020 \\
\hline 0.32 & 0.35 & 0.38 & 0.28 & 0.31 & 0.39 & 0.046 \\
\hline 0.32 & 0.33 & 0.32 & 0.34 & 0.31 & 0.40 & 0.034 \\
\hline 0.34 & 0.37 & 0.39 & 0.37 & 0.32 & 0.39 & 0.029 \\
\hline 0.29 & 0.34 & 0.37 & 0.37 & 0.31 & 0.40 & 0.052 \\
\hline 0.34 & 0.38 & 0.38 & 0.34 & 0.32 & 0.40 & 0.037 \\
\hline 0.34 & 0.38 & 0.41 & 0.39 & 0.31 & 0.40 & 0.047 \\
\hline 0.37 & 0.37 & 0.41 & 0.35 & 0.33 & 0.39 & 0.027 \\
\hline 0.34 & 0.39 & 0.37 & 0.43 & 0.32 & 0.41 & 0.040 \\
\hline 0.32 & 0.33 & 0.38 & 0.39 & 0.35 & 0.40 & 0.026 \\
\hline 0.18 & 0.33 & 0.36 & 0.40 & 0.30 & 0.40 & 0.022 \\
\hline 0.20 & 0.30 & 0.37 & 0.37 & 0.34 & 0.41 & 0.034 \\
\hline 0.29 & 0.31 & 0.32 & 0.42 & 0.34 & 0.41 & 0.022 \\
\hline 0.33 & 0.29 & 0.36 & 0.41 & 0.33 & 0.40 & 0.024 \\
\hline 0.35 & 0.30 & 0.29 & 0.40 & 0.33 & 0.41 & 0.013 \\
\hline 0.37 & 0.29 & 0.26 & 0.43 & 0.34 & 0.42 & 0.020 \\
\hline 0.38 & 0.34 & 0.29 & 0.40 & 0.36 & 0.41 & 0.042 \\
\hline 0.38 & 0.31 & 0.31 & 0.42 & 0.34 & 0.40 & 0.019 \\
\hline 0.37 & 0.33 & 0.29 & 0.45 & 0.34 & 0.41 & 0.035 \\
\hline 0.40 & 0.31 & 0.35 & 0.43 & 0.37 & 0.41 & 0.021 \\
\hline 0.43 & 0.39 & 0.37 & 0.42 & 0.33 & 0.42 & 0.041 \\
\hline
\end{tabular}




\begin{tabular}{|c|c|c|c|c|}
\hline 0.44 & 0.34 & 0.35 & 0.45 & 0.37 \\
\hline 0.42 & 0.39 & 0.39 & 0.46 & 0.33 \\
\hline 0.44 & 0.29 & 0.37 & 0.43 & 0.38 \\
\hline 0.45 & 0.28 & 0.38 & 0.40 & 0.38 \\
\hline 0.44 & 0.26 & 0.39 & 0.43 & 0.36 \\
\hline 0.45 & 0.26 & 0.40 & 0.41 & 0.37 \\
\hline 0.44 & 0.27 & 0.41 & 0.37 & 0.32 \\
\hline 0.44 & 0.28 & 0.41 & 0.36 & 0.36 \\
\hline 0.41 & 0.31 & 0.39 & 0.34 & 0.39 \\
\hline 0.42 & 0.33 & 0.38 & 0.26 & 0.36 \\
\hline 0.40 & 0.34 & 0.37 & 0.16 & 0.35 \\
\hline 0.41 & 0.28 & 0.35 & 0.27 & 0.36 \\
\hline 0.39 & 0.33 & 0.32 & 0.37 & 0.36 \\
\hline 0.40 & 0.29 & 0.28 & 0.33 & 0.39 \\
\hline 0.39 & 0.29 & 0.25 & 0.31 & 0.37 \\
\hline 0.40 & 0.33 & 0.27 & 0.26 & 0.36 \\
\hline 0.37 & 0.39 & 0.28 & 0.32 & 0.33 \\
\hline 0.31 & 0.34 & 0.28 & 0.34 & 0.33 \\
\hline 0.35 & 0.35 & 0.37 & 0.34 & 0.32 \\
\hline 0.35 & 0.32 & 0.33 & 0.39 & 0.33 \\
\hline 0.41 & 0.31 & 0.29 & 0.34 & 0.36 \\
\hline 0.40 & 0.36 & 0.28 & 0.34 & 0.33 \\
\hline 0.39 & 0.31 & 0.37 & & 0.28 \\
\hline 0.38 & 0.25 & 0.42 & & 0.29 \\
\hline 0.38 & 0.34 & 0.38 & & 0.28 \\
\hline 0.33 & 0.32 & 0.38 & & 0.23 \\
\hline 0.32 & 0.31 & 0.42 & & 0.25 \\
\hline 0.31 & 0.23 & 0.39 & & 0.21 \\
\hline 0.34 & 0.24 & 0.41 & & 0.23 \\
\hline 0.32 & 0.27 & 0.46 & & 0.16 \\
\hline 0.30 & 0.23 & 0.47 & & 0.18 \\
\hline 0.32 & 0.26 & 0.48 & & \\
\hline \multirow[t]{5}{*}{0.26} & & 0.47 & & \\
\hline & & 0.46 & & \\
\hline & & 0.50 & & \\
\hline & & 0.49 & & \\
\hline & & 0.42 & & \\
\hline
\end{tabular}

0.42

0.020

0.41

0.035

0.42

0.038

0.41

0.033

0.41

0.027

0.40

0.018

0.41

0.027

0.41

0.061

0.39

0.052

0.43

0.033

0.42

0.058

0.41

0.048

0.40

0.065

0.42

0.069

0.42

0.059

0.43

0.065

0.44

0.060

0.42

0.097

0.38

0.108

0.39

0.123

0.33

0.119

0.34

0.167

0.33

0.185

0.32

0.166

0.33

0.136

0.35

0.111

0.34

0.069

0.30

0.051

0.29

0.059

0.29

0.063

0.25

0.043

0.24

0.047

0.21

0.085

0.26

0.037

0.27

0.006

0.26

0.002

0.26

0.25

0.26

0.33

0.27 
Lethaia

Page 50 of 83

$$
\begin{aligned}
& 1 \\
& \begin{array}{l}
2 \\
3
\end{array} \\
& 4 \\
& 5 \\
& 6 \\
& 7 \\
& 8 \\
& 9 \\
& 10 \\
& 11 \\
& 12 \\
& 13 \\
& 14 \\
& 15 \\
& 16 \\
& 17 \\
& 18 \\
& 19 \\
& 20 \\
& 21 \\
& 22 \\
& 23 \\
& 24 \\
& 25 \\
& 26 \\
& 27 \\
& 28 \\
& 29 \\
& 30 \\
& 31 \\
& 32 \\
& 33 \\
& 34 \\
& 35 \\
& 36 \\
& 37 \\
& 38 \\
& 39 \\
& 40 \\
& 41 \\
& 42 \\
& 43 \\
& 44 \\
& 45 \\
& 46 \\
& 47 \\
& 48 \\
& 49 \\
& 50 \\
& 51 \\
& 52 \\
& 53 \\
& 54 \\
& 55 \\
& 56 \\
& 57 \\
& 58 \\
& 59 \\
& 60
\end{aligned}
$$

Lethaia - manuscript copy 


\begin{tabular}{|c|c|c|c|c|c|}
\hline $\begin{array}{l}\text { average } \\
\text { (Harima) }\end{array}$ & $\begin{array}{l}\text { standard } \\
\text { deviation } \\
\text { (Harima) }\end{array}$ & $\begin{array}{l}\text { average } \\
\text { (all) }\end{array}$ & $\begin{array}{l}\text { standard } \\
\text { deviation } \\
\text { (all) }\end{array}$ & $\begin{array}{l}\text { MO01 } \\
\text { Sea of } \\
\text { Harima }\end{array}$ & $\begin{array}{l}\text { MO02 } \\
\text { Sea of } \\
\text { Harima }\end{array}$ \\
\hline 0.16 & 0.026 & 0.16 & 0.025 & 0.20 & 0.21 \\
\hline 0.21 & 0.013 & 0.19 & 0.029 & 0.24 & 0.23 \\
\hline 0.21 & 0.019 & 0.20 & 0.027 & 0.20 & 0.26 \\
\hline 0.20 & 0.020 & 0.18 & 0.029 & 0.20 & 0.22 \\
\hline 0.18 & 0.011 & 0.18 & 0.015 & 0.20 & 0.19 \\
\hline 0.16 & 0.016 & 0.15 & 0.014 & 0.10 & 0.15 \\
\hline 0.12 & 0.013 & 0.12 & 0.016 & 0.13 & 0.13 \\
\hline 0.10 & 0.012 & 0.09 & 0.012 & 0.13 & 0.28 \\
\hline 0.10 & 0.007 & 0.10 & 0.011 & 0.11 & 0.20 \\
\hline 0.13 & 0.008 & 0.13 & 0.010 & 0.19 & 0.19 \\
\hline 0.15 & 0.015 & 0.13 & 0.017 & 0.13 & 0.19 \\
\hline 0.15 & 0.026 & 0.13 & 0.027 & 0.17 & 0.19 \\
\hline 0.17 & 0.026 & 0.15 & 0.025 & 0.16 & 0.21 \\
\hline 0.17 & 0.012 & 0.15 & 0.028 & 0.18 & 0.19 \\
\hline 0.17 & 0.020 & 0.16 & 0.039 & 0.17 & 0.23 \\
\hline 0.19 & 0.026 & 0.16 & 0.036 & 0.22 & 0.23 \\
\hline 0.18 & 0.025 & 0.17 & 0.026 & 0.22 & 0.23 \\
\hline 0.19 & 0.024 & 0.17 & 0.030 & 0.23 & 0.26 \\
\hline 0.19 & 0.012 & 0.17 & 0.019 & 0.22 & 0.23 \\
\hline 0.20 & 0.023 & 0.18 & 0.032 & 0.24 & 0.30 \\
\hline 0.20 & 0.026 & 0.18 & 0.029 & 0.27 & 0.25 \\
\hline 0.20 & 0.020 & 0.18 & 0.026 & 0.27 & 0.27 \\
\hline 0.21 & 0.030 & 0.19 & 0.048 & 0.25 & 0.29 \\
\hline 0.22 & 0.037 & 0.20 & 0.041 & 0.29 & 0.23 \\
\hline 0.21 & 0.054 & 0.20 & 0.039 & 0.30 & 0.29 \\
\hline 0.24 & 0.031 & 0.22 & 0.033 & 0.29 & 0.27 \\
\hline 0.26 & 0.023 & 0.24 & 0.031 & 0.32 & 0.25 \\
\hline 0.26 & 0.028 & 0.24 & 0.034 & 0.32 & 0.32 \\
\hline 0.27 & 0.026 & 0.25 & 0.031 & 0.30 & 0.26 \\
\hline 0.27 & 0.036 & 0.25 & 0.033 & 0.32 & 0.30 \\
\hline 0.27 & 0.045 & 0.26 & 0.038 & 0.31 & 0.32 \\
\hline 0.26 & 0.028 & 0.25 & 0.025 & 0.31 & 0.29 \\
\hline 0.27 & 0.026 & 0.26 & 0.024 & 0.30 & 0.31 \\
\hline 0.26 & 0.038 & 0.26 & 0.028 & 0.30 & 0.33 \\
\hline 0.25 & 0.069 & 0.25 & 0.048 & 0.31 & 0.35 \\
\hline 0.26 & 0.059 & 0.27 & 0.044 & 0.31 & 0.35 \\
\hline 0.25 & 0.064 & 0.27 & 0.049 & 0.31 & 0.33 \\
\hline 0.27 & 0.057 & 0.27 & 0.045 & 0.37 & 0.34 \\
\hline 0.26 & 0.066 & 0.28 & 0.050 & 0.36 & 0.35 \\
\hline 0.25 & 0.048 & 0.27 & 0.044 & 0.35 & 0.35 \\
\hline 0.25 & 0.056 & 0.27 & 0.050 & 0.33 & 0.41 \\
\hline 0.25 & 0.029 & 0.27 & 0.035 & 0.33 & 0.36 \\
\hline 0.26 & 0.044 & 0.28 & 0.042 & 0.28 & 0.36 \\
\hline 0.24 & 0.058 & 0.28 & 0.053 & 0.34 & 0.39 \\
\hline 0.24 & 0.063 & 0.27 & 0.058 & 0.33 & 0.35 \\
\hline 0.27 & 0.025 & 0.28 & 0.036 & 0.33 & 0.39 \\
\hline
\end{tabular}




\begin{tabular}{|c|c|c|c|c|c|}
\hline 0.28 & 0.026 & 0.30 & 0.036 & 0.35 & 0.39 \\
\hline 0.27 & 0.031 & 0.29 & 0.034 & 0.33 & 0.40 \\
\hline 0.27 & 0.040 & 0.29 & 0.040 & 0.36 & 0.46 \\
\hline 0.27 & 0.036 & 0.30 & 0.040 & 0.38 & 0.45 \\
\hline 0.27 & 0.023 & 0.29 & 0.032 & 0.34 & 0.43 \\
\hline 0.26 & 0.034 & 0.29 & 0.045 & 0.38 & 0.45 \\
\hline 0.27 & 0.030 & 0.29 & 0.042 & 0.41 & 0.45 \\
\hline 0.28 & 0.043 & 0.31 & 0.047 & 0.41 & 0.42 \\
\hline 0.27 & 0.063 & 0.29 & 0.056 & 0.43 & 0.45 \\
\hline 0.26 & 0.071 & 0.30 & 0.062 & 0.43 & 0.45 \\
\hline 0.26 & 0.067 & 0.29 & 0.063 & 0.42 & 0.45 \\
\hline 0.29 & 0.046 & 0.29 & 0.072 & 0.43 & 0.46 \\
\hline 0.29 & 0.043 & 0.31 & 0.052 & 0.42 & 0.44 \\
\hline 0.29 & 0.030 & 0.30 & 0.041 & 0.42 & 0.45 \\
\hline 0.28 & 0.053 & 0.31 & 0.049 & 0.44 & 0.45 \\
\hline 0.28 & 0.052 & 0.31 & 0.044 & 0.42 & 0.43 \\
\hline 0.28 & 0.077 & 0.31 & 0.066 & 0.41 & 0.47 \\
\hline 0.28 & 0.086 & 0.31 & 0.066 & 0.39 & 0.4 \\
\hline 0.29 & 0.056 & 0.32 & 0.051 & 0.40 & 0.44 \\
\hline 0.29 & 0.036 & 0.32 & 0.045 & 0.39 & 0.45 \\
\hline 0.30 & 0.030 & 0.33 & 0.042 & 0.40 & 0.45 \\
\hline 0.28 & 0.033 & 0.32 & 0.053 & 0.40 & 0.47 \\
\hline 0.30 & 0.025 & 0.33 & 0.046 & 0.41 & 0.48 \\
\hline 0.30 & 0.026 & 0.33 & 0.041 & 0.43 & 0.46 \\
\hline 0.32 & 0.029 & 0.35 & 0.043 & 0.43 & 0.46 \\
\hline 0.33 & 0.034 & 0.35 & 0.037 & 0.40 & 0.44 \\
\hline 0.35 & 0.028 & 0.37 & 0.027 & 0.44 & 0.48 \\
\hline 0.35 & 0.025 & 0.36 & 0.032 & 0.40 & 0.47 \\
\hline 0.35 & 0.027 & 0.37 & 0.033 & 0.46 & 0.45 \\
\hline 0.36 & 0.039 & 0.37 & 0.031 & 0.41 & 0.48 \\
\hline 0.35 & 0.033 & 0.37 & 0.036 & 0.45 & 0.46 \\
\hline 0.33 & 0.037 & 0.35 & 0.034 & 0.48 & 0.47 \\
\hline 0.33 & 0.036 & 0.36 & 0.048 & 0.43 & 0.47 \\
\hline 0.32 & 0.013 & 0.36 & 0.044 & 0.42 & 0.47 \\
\hline 0.36 & 0.028 & 0.37 & 0.030 & 0.45 & 0.47 \\
\hline 0.34 & 0.036 & 0.37 & 0.051 & 0.46 & 0.46 \\
\hline 0.35 & 0.028 & 0.38 & 0.039 & 0.45 & 0.48 \\
\hline 0.37 & 0.044 & 0.38 & 0.043 & 0.45 & 0.51 \\
\hline 0.37 & 0.028 & 0.38 & 0.027 & 0.47 & 0.48 \\
\hline 0.37 & 0.042 & 0.39 & 0.042 & 0.47 & 0.47 \\
\hline 0.35 & 0.030 & 0.37 & 0.034 & 0.46 & 0.51 \\
\hline 0.32 & 0.083 & 0.36 & 0.070 & 0.45 & 0.51 \\
\hline 0.32 & 0.069 & 0.36 & 0.068 & 0.50 & 0.54 \\
\hline 0.34 & 0.050 & 0.38 & 0.052 & 0.45 & 0.51 \\
\hline 0.34 & 0.043 & 0.37 & 0.042 & 0.48 & 0.51 \\
\hline 0.33 & 0.042 & 0.37 & 0.048 & 0.46 & 0.52 \\
\hline 0.34 & 0.066 & 0.38 & 0.059 & 0.47 & 0.54 \\
\hline 0.35 & 0.044 & 0.38 & 0.049 & 0.47 & 0.55 \\
\hline 0.35 & 0.047 & 0.38 & 0.041 & 0.48 & 0.56 \\
\hline 0.35 & 0.059 & 0.38 & 0.052 & 0.47 & \\
\hline 0.37 & 0.047 & 0.39 & 0.038 & 0.45 & \\
\hline 0.39 & 0.041 & 0.40 & 0.039 & 0.50 & 0.54 \\
\hline
\end{tabular}




\begin{tabular}{|c|c|c|c|c|c|}
\hline 0.39 & 0.054 & 0.40 & 0.039 & 0.51 & 0.52 \\
\hline 0.40 & 0.046 & 0.40 & 0.037 & 0.47 & 0.54 \\
\hline 0.38 & 0.062 & 0.40 & 0.050 & 0.51 & 0.55 \\
\hline 0.38 & 0.063 & 0.39 & 0.047 & 0.52 & 0.57 \\
\hline 0.38 & 0.072 & 0.39 & 0.051 & 0.54 & 0.53 \\
\hline 0.38 & 0.070 & 0.39 & 0.046 & 0.50 & 0.55 \\
\hline 0.36 & 0.068 & 0.39 & 0.051 & 0.50 & 0.51 \\
\hline 0.37 & 0.059 & 0.39 & 0.057 & 0.51 & 0.55 \\
\hline 0.37 & 0.041 & 0.38 & 0.043 & 0.52 & 0.53 \\
\hline 0.35 & 0.061 & 0.39 & 0.058 & 0.52 & 0.54 \\
\hline 0.32 & 0.093 & 0.37 & 0.084 & 0.53 & 0.51 \\
\hline 0.33 & 0.059 & 0.37 & 0.063 & 0.49 & 0.55 \\
\hline 0.35 & 0.030 & 0.38 & 0.052 & 0.52 & 0.53 \\
\hline 0.34 & 0.057 & 0.38 & 0.069 & 0.50 & 0.50 \\
\hline 0.32 & 0.057 & 0.37 & 0.071 & 0.49 & 0.50 \\
\hline 0.32 & 0.056 & 0.37 & 0.075 & 0.52 & 0.51 \\
\hline 0.34 & 0.044 & 0.39 & 0.070 & 0.52 & 0.52 \\
\hline 0.32 & 0.026 & 0.37 & 0.083 & 0.48 & 0.52 \\
\hline 0.34 & 0.018 & 0.36 & 0.072 & 0.47 & 0.54 \\
\hline 0.34 & 0.029 & 0.37 & 0.083 & 0.49 & 0.52 \\
\hline 0.34 & 0.044 & 0.34 & 0.081 & 0.48 & 0.53 \\
\hline 0.34 & 0.042 & 0.34 & 0.100 & 0.44 & 0.52 \\
\hline 0.34 & 0.052 & 0.34 & 0.118 & 0.46 & 0.51 \\
\hline 0.33 & 0.075 & 0.33 & 0.112 & 0.47 & 0.45 \\
\hline 0.34 & 0.050 & 0.34 & 0.090 & 0.42 & 0.49 \\
\hline 0.32 & 0.063 & 0.33 & 0.074 & 0.39 & 0.47 \\
\hline 0.32 & 0.072 & 0.33 & 0.061 & 0.40 & 0.50 \\
\hline 0.29 & 0.080 & 0.29 & 0.060 & 0.43 & 0.50 \\
\hline 0.30 & 0.085 & 0.30 & 0.065 & 0.45 & 0.51 \\
\hline 0.30 & 0.122 & 0.30 & 0.087 & 0.47 & 0.50 \\
\hline 0.30 & 0.122 & 0.28 & 0.086 & 0.38 & 0.50 \\
\hline 0.35 & 0.113 & 0.30 & 0.090 & 0.36 & 0.47 \\
\hline 0.37 & 0.146 & 0.27 & 0.113 & 0.43 & 0.47 \\
\hline 0.46 & & 0.32 & 0.098 & 0.46 & 0.43 \\
\hline 0.50 & & 0.35 & 0.106 & 0.44 & 0.48 \\
\hline 0.49 & & 0.34 & 0.106 & 0.49 & 0.47 \\
\hline \multirow[t]{16}{*}{0.42} & & 0.34 & 0.080 & 0.49 & 0.45 \\
\hline & & 0.25 & & 0.50 & 0.46 \\
\hline & & 0.26 & & 0.51 & 0.48 \\
\hline & & 0.33 & & 0.46 & 0.45 \\
\hline & & 0.27 & & 0.44 & 0.45 \\
\hline & & & & 0.43 & 0.44 \\
\hline & & & & 0.36 & \\
\hline & & & & 0.41 & 0.41 \\
\hline & & & & 0.39 & 0.40 \\
\hline & & & & 0.36 & \\
\hline & & & & 0.35 & 0.39 \\
\hline & & & & 0.36 & 0.39 \\
\hline & & & & 0.38 & \\
\hline & & & & 0.37 & 0.3 \\
\hline & & & & 0.33 & \\
\hline & & & & 0.27 & 0.36 \\
\hline
\end{tabular}


0.31

0.30

0.23 
Sepia lycidas

MO03
Sea of
Harima

0.18

0.27

0.19

0.20

0.18

0.16

0.16

0.13

0.11

0.19

0.19

0.20

0.11

0.14

0.24

0.28

0.28

0.20

0.25

0.19

0.20

0.25

0.21

0.26

0.34

0.31

0.29

0.29

0.32

0.30

0.30

0.36

0.33

0.36

0.35

0.39

0.35

0.39

0.37

0.38

0.38

0.39

0.40

0.41

0.43

0.45

\section{HM01}

Sea of

Harima

0.20

0.24

0.25

0.20

0.26

0.15

0.15

0.13

0.17

0.21

0.13

0.07

0.16

0.17

0.21

0.20

0.25

0.21

0.17

0.17

0.16

0.20

0.21

0.18

0.21

0.25

0.23

0.26

0.27

0.28

0.29

0.28

0.30

0.29

0.29

0.31

0.30

0.35

0.36

0.37

0.38

0.35

0.40

0.39

0.41

0.41
HM05

Sea of

Harima
0.20
0.19
0.19
0.19

0.18

0.14

0.15

0.18

0.18

0.18

0.17

0.22

0.22

0.26

0.26

0.23

0.27

0.28

0.30

0.32

0.32

0.35

0.29

0.38

0.36

0.36

0.32

0.30

0.28

0.24

0.24

0.29

0.33

0.32

0.35

0.34

0.36

0.37

0.41

0.35

0.36

0.36

0.38 average

0.20
0.23
0.22

0.20

0.21

0.14

0.14

0.17

0.15

0.18

0.16

0.16

0.16

0.17

0.21

0.23

0.25

0.23

0.22

0.23

0.23

0.26

0.25

0.26

0.30

0.28

0.29

0.31

0.30

0.30

0.30

0.30

0.29

0.30

0.32

0.34

0.32

0.36

0.35

0.36

0.37

0.37

0.36

0.38

0.38

0.39 standard

deviation

0.002

0.027

0.031

0.011

0.031

0.022

0.014

0.057

0.035

0.017

0.028

0.047

0.033

0.016

0.026

0.028

0.021

0.025

0.028

0.048

0.046

0.033

0.044

0.048

0.052

0.023

0.050

0.033

0.037

0.013

0.011

0.030

0.029

0.041

0.026

0.031

0.018

0.019

0.009

0.010

0.025

0.031

0.043

0.026

0.037

0.040

KO02

Okinawa

0.19

0.27

0.27

0.24

0.23

0.25

0.28

0.29

0.31

0.23

0.23

0.23

0.23

0.15

0.13

0.09

0.06

0.10

0.13

0.14

0.14

0.11

0.16

0.22

0.19

0.23

0.22

0.22

0.22

0.26

0.22

0.24

0.30

0.26

0.24

0.26

0.26

0.21

0.23

0.25

0.29

0.28

0.29

0.31

0.29

0.28 


\begin{tabular}{|c|c|c|c|c|c|}
\hline 0.43 & 0.41 & 0.34 & 0.38 & 0.033 & 0.29 \\
\hline 0.45 & 0.41 & 0.37 & 0.39 & 0.038 & 0.36 \\
\hline 0.45 & 0.40 & 0.39 & 0.41 & 0.039 & 0.35 \\
\hline 0.47 & 0.39 & 0.36 & 0.41 & 0.041 & 0.37 \\
\hline 0.46 & 0.39 & 0.37 & 0.40 & 0.042 & 0.38 \\
\hline 0.46 & 0.41 & 0.38 & 0.42 & 0.035 & 0.37 \\
\hline 0.44 & 0.41 & 0.39 & 0.42 & 0.020 & 0.39 \\
\hline 0.43 & 0.41 & 0.34 & 0.40 & 0.032 & 0.37 \\
\hline 0.43 & 0.42 & 0.38 & 0.42 & 0.021 & 0.34 \\
\hline 0.45 & 0.42 & 0.38 & 0.43 & 0.026 & 0.36 \\
\hline 0.44 & 0.42 & 0.35 & 0.42 & 0.034 & 0.36 \\
\hline 0.46 & 0.47 & 0.39 & 0.44 & 0.029 & 0.34 \\
\hline 0.46 & 0.43 & 0.43 & 0.44 & 0.015 & 0.32 \\
\hline 0.41 & 0.46 & 0.44 & 0.44 & 0.017 & 0.31 \\
\hline 0.44 & 0.45 & 0.44 & 0.44 & 0.006 & 0.37 \\
\hline 0.44 & 0.47 & 0.47 & 0.45 & 0.021 & 0.36 \\
\hline 0.44 & 0.42 & 0.49 & 0.45 & 0.030 & 0.39 \\
\hline 0.43 & 0.45 & 0.47 & 0.43 & 0.026 & 0.42 \\
\hline 0.46 & 0.45 & 0.45 & 0.44 & 0.020 & 0.41 \\
\hline 0.43 & 0.44 & 0.46 & 0.43 & 0.026 & 0.40 \\
\hline 0.47 & 0.49 & 0.44 & 0.45 & 0.028 & 0.43 \\
\hline 0.46 & 0.48 & 0.44 & 0.45 & 0.029 & 0.45 \\
\hline 0.50 & 0.48 & 0.45 & 0.46 & 0.032 & 0.47 \\
\hline 0.48 & 0.50 & 0.47 & 0.47 & 0.022 & 0.46 \\
\hline 0.47 & 0.50 & 0.44 & 0.46 & 0.023 & 0.43 \\
\hline 0.49 & 0.48 & 0.46 & 0.45 & 0.033 & 0.45 \\
\hline 0.50 & 0.48 & 0.45 & 0.47 & 0.020 & 0.44 \\
\hline 0.49 & 0.45 & 0.47 & 0.45 & 0.028 & 0.37 \\
\hline 0.48 & 0.50 & 0.46 & 0.47 & 0.019 & 0.39 \\
\hline 0.52 & 0.46 & 0.47 & 0.47 & 0.032 & 0.40 \\
\hline 0.50 & 0.49 & 0.48 & 0.48 & 0.018 & 0.42 \\
\hline 0.50 & 0.49 & 0.45 & 0.48 & 0.018 & 0.45 \\
\hline 0.47 & 0.49 & 0.42 & 0.46 & 0.026 & 0.42 \\
\hline 0.52 & 0.48 & 0.43 & 0.46 & 0.038 & 0.46 \\
\hline 0.51 & 0.49 & 0.44 & 0.47 & 0.023 & 0.43 \\
\hline 0.51 & 0.48 & 0.46 & 0.47 & 0.016 & 0.48 \\
\hline 0.47 & 0.51 & 0.47 & 0.47 & 0.018 & 0.45 \\
\hline 0.44 & 0.50 & 0.45 & 0.47 & 0.028 & 0.43 \\
\hline 0.49 & 0.53 & 0.48 & 0.49 & 0.022 & 0.49 \\
\hline 0.47 & 0.48 & 0.48 & 0.48 & 0.006 & 0.48 \\
\hline 0.50 & 0.55 & 0.48 & 0.50 & 0.029 & 0.48 \\
\hline 0.50 & 0.52 & 0.47 & 0.49 & 0.027 & 0.47 \\
\hline 0.51 & 0.54 & 0.53 & 0.53 & 0.017 & 0.49 \\
\hline 0.50 & 0.50 & 0.51 & 0.49 & 0.022 & 0.50 \\
\hline 0.51 & 0.51 & 0.53 & 0.51 & 0.016 & 0.48 \\
\hline 0.45 & 0.54 & 0.50 & 0.49 & 0.033 & 0.47 \\
\hline 0.54 & 0.49 & 0.49 & 0.50 & 0.028 & 0.50 \\
\hline 0.49 & 0.52 & 0.49 & 0.50 & 0.028 & 0.46 \\
\hline 0.52 & 0.52 & 0.48 & 0.51 & 0.029 & 0.46 \\
\hline 0.51 & 0.50 & 0.49 & 0.50 & 0.018 & 0.48 \\
\hline 0.50 & 0.50 & 0.50 & 0.50 & 0.038 & 0.45 \\
\hline 0.51 & 0.54 & 0.49 & 0.52 & 0.021 & 0.48 \\
\hline
\end{tabular}




\begin{tabular}{|c|c|c|c|c|c|}
\hline 0.50 & 0.56 & 0.52 & 0.52 & 0.022 & 0.48 \\
\hline 0.52 & 0.52 & 0.51 & 0.51 & 0.021 & 0.47 \\
\hline 0.55 & 0.52 & 0.50 & 0.53 & 0.020 & 0.47 \\
\hline 0.54 & 0.55 & 0.53 & 0.54 & 0.017 & 0.47 \\
\hline 0.52 & 0.52 & 0.49 & 0.52 & 0.018 & 0.40 \\
\hline 0.48 & 0.54 & 0.51 & 0.52 & 0.025 & 0.45 \\
\hline 0.49 & 0.49 & 0.50 & 0.50 & 0.008 & 0.50 \\
\hline 0.50 & 0.54 & 0.51 & 0.52 & 0.019 & 0.48 \\
\hline 0.50 & 0.42 & 0.47 & 0.49 & 0.039 & 0.46 \\
\hline 0.51 & 0.45 & 0.48 & 0.50 & 0.031 & 0.50 \\
\hline 0.49 & 0.50 & 0.47 & 0.50 & 0.020 & 0.48 \\
\hline 0.51 & 0.52 & 0.48 & 0.51 & 0.026 & 0.46 \\
\hline 0.52 & 0.50 & 0.48 & 0.51 & 0.017 & 0.50 \\
\hline 0.49 & 0.48 & 0.54 & 0.50 & 0.023 & 0.51 \\
\hline 0.53 & 0.46 & 0.52 & 0.50 & 0.022 & 0.45 \\
\hline 0.51 & 0.49 & 0.50 & 0.51 & 0.011 & 0.46 \\
\hline 0.50 & 0.51 & 0.49 & 0.51 & 0.014 & 0.45 \\
\hline 0.48 & 0.52 & 0.52 & 0.50 & 0.019 & 0.46 \\
\hline 0.51 & 0.51 & 0.49 & 0.50 & 0.024 & 0.46 \\
\hline 0.48 & 0.48 & 0.51 & 0.49 & 0.015 & 0.49 \\
\hline 0.48 & 0.50 & 0.49 & 0.50 & 0.017 & 0.43 \\
\hline 0.48 & 0.48 & 0.50 & 0.48 & 0.026 & 0.44 \\
\hline 0.48 & 0.46 & 0.49 & 0.48 & 0.020 & 0.43 \\
\hline 0.49 & 0.44 & 0.51 & 0.47 & 0.026 & 0.39 \\
\hline 0.52 & 0.44 & 0.50 & 0.47 & 0.038 & 0.47 \\
\hline 0.49 & 0.41 & 0.46 & 0.44 & 0.037 & 0.46 \\
\hline 0.49 & 0.40 & 0.45 & 0.45 & 0.042 & 0.44 \\
\hline 0.51 & 0.40 & 0.51 & 0.47 & 0.045 & 0.47 \\
\hline 0.51 & 0.39 & 0.50 & 0.47 & 0.046 & 0.43 \\
\hline 0.49 & 0.16 & 0.52 & 0.43 & 0.133 & 0.45 \\
\hline 0.47 & 0.11 & 0.48 & 0.39 & 0.144 & 0.45 \\
\hline 0.48 & 0.35 & 0.53 & 0.44 & 0.071 & 0.41 \\
\hline 0.51 & 0.37 & 0.49 & 0.45 & 0.051 & 0.46 \\
\hline 0.50 & 0.35 & 0.49 & 0.45 & 0.053 & 0.43 \\
\hline 0.51 & 0.37 & 0.45 & 0.45 & 0.047 & 0.40 \\
\hline 0.50 & 0.36 & 0.44 & 0.45 & 0.051 & 0.39 \\
\hline 0.49 & 0.37 & 0.46 & 0.45 & 0.043 & 0.45 \\
\hline 0.45 & 0.36 & 0.46 & 0.44 & 0.046 & 0.41 \\
\hline 0.45 & 0.37 & 0.40 & 0.44 & 0.052 & 0.43 \\
\hline 0.45 & 0.33 & 0.38 & 0.41 & 0.051 & 0.35 \\
\hline 0.45 & 0.30 & 0.37 & 0.40 & 0.059 & 0.31 \\
\hline 0.44 & 0.29 & 0.44 & 0.41 & 0.058 & 0.37 \\
\hline 0.44 & 0.30 & 0.40 & 0.38 & 0.046 & 0.32 \\
\hline 0.39 & 0.30 & 0.42 & 0.39 & 0.043 & 0.38 \\
\hline 0.36 & 0.32 & 0.39 & 0.37 & 0.028 & 0.36 \\
\hline 0.39 & 0.33 & 0.38 & 0.38 & 0.026 & 0.41 \\
\hline 0.37 & 0.36 & 0.41 & 0.37 & 0.020 & 0.42 \\
\hline 0.39 & 0.39 & 0.45 & 0.40 & 0.028 & 0.40 \\
\hline 0.38 & 0.33 & 0.39 & 0.37 & 0.021 & 0.36 \\
\hline 0.34 & 0.33 & 0.41 & 0.37 & 0.031 & 0.37 \\
\hline 0.36 & 0.28 & 0.41 & 0.35 & 0.043 & 0.34 \\
\hline 0.35 & 0.21 & 0.44 & 0.32 & 0.079 & 0.31 \\
\hline
\end{tabular}




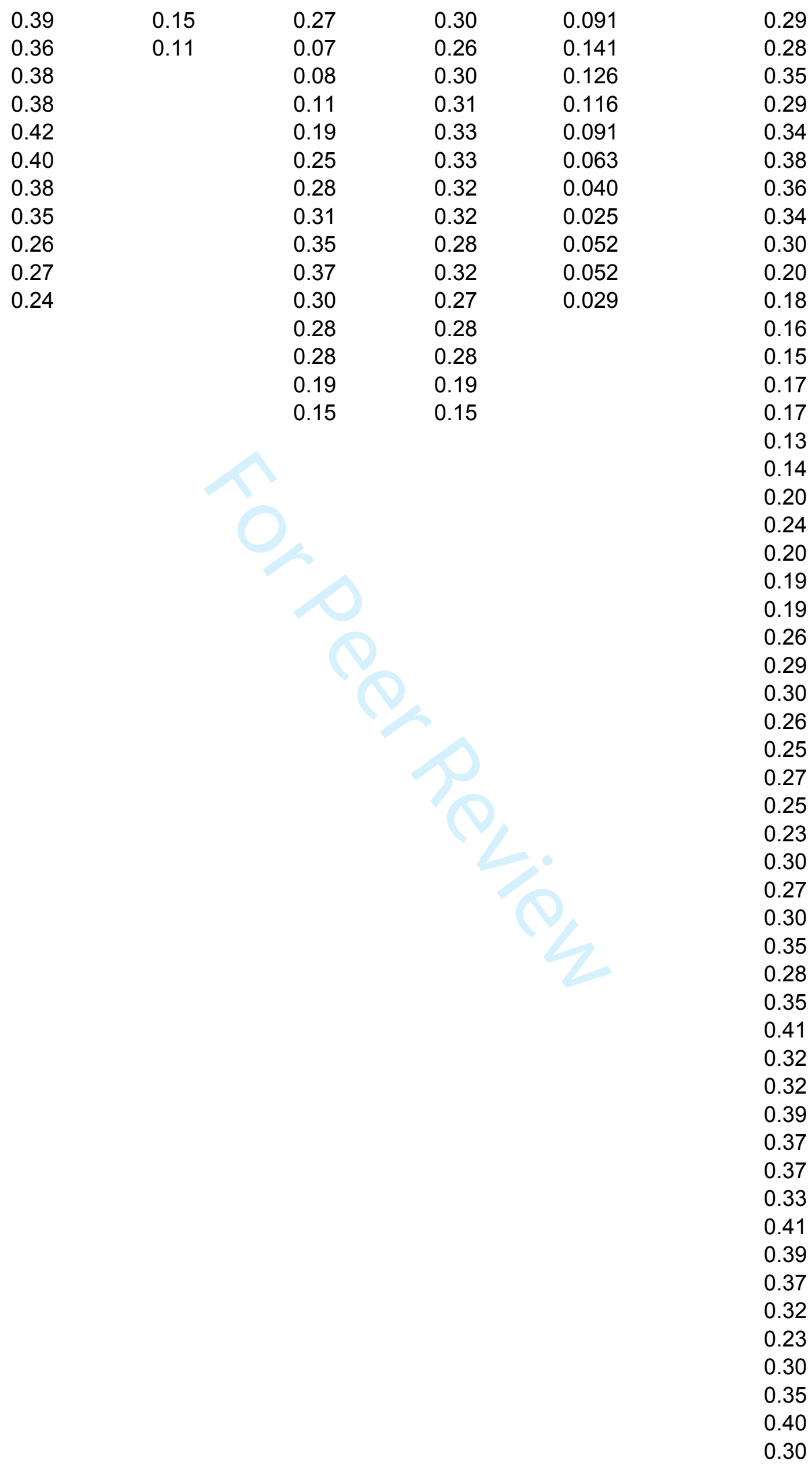


Lethaia

Page 60 of 83

$$
\begin{aligned}
& 1 \\
& \begin{array}{l}
2 \\
3
\end{array} \\
& 4 \\
& 5 \\
& 6 \\
& 7 \\
& 8 \\
& 9 \\
& 10 \\
& 11 \\
& 12 \\
& 13 \\
& 14 \\
& 15 \\
& 16 \\
& 17 \\
& 18 \\
& 19 \\
& 20 \\
& 21 \\
& 22 \\
& 23 \\
& 24 \\
& 25 \\
& 26 \\
& 27 \\
& 28 \\
& 29 \\
& 30 \\
& 31 \\
& 32 \\
& 33 \\
& 34 \\
& 35 \\
& 36 \\
& 37 \\
& 38 \\
& 39 \\
& 40 \\
& 41 \\
& 42 \\
& 43 \\
& 44 \\
& 45 \\
& 46 \\
& 47 \\
& 48 \\
& 49 \\
& 50 \\
& 51 \\
& 52 \\
& 53 \\
& 54 \\
& 55 \\
& 56 \\
& 57 \\
& 58 \\
& \begin{array}{l}
59 \\
60
\end{array}
\end{aligned}
$$

0.26
0.25
0.26
0.24
0.20
0.22
0.23
0.27
0.20
0.21
0.21
0.21
0.24
0.13
0.13
0.10
0.13
0.09
0.08
0.08
0.10
0.11

Lethaia - manuscript copy 
Sepia latimanus

$\mathrm{KO} 03$

Okinawa

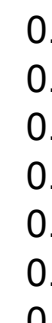

0.19

0.29

0.28

0.24

0.27

0.28

0.30

0.28

0.23

0.24

0.20

0.25

0.20

0.15

0.16

0.14

0.10

0.10

0.10

0.11

0.19

0.20

0.20

0.21

0.19

0.19

0.23

0.24

0.21

0.19

0.21

0.25

0.24

0.25

0.25

0.25

0.27

0.27

0.29

0.28

0.30

0.29

0.31

0.35

0.37

0.33 average

standard

deviation

0.19

0.28

0.28

0.24

0.25

0.27

0.29

0.29

0.27

0.23

0.21

0.24

0.21

0.15

0.14

0.12

0.08

0.10

0.12

0.12

0.16

0.16

0.18

0.22

0.19

0.21

0.22

0.23

0.22

0.22

0.21

0.24

0.27

0.25

0.25

0.25

0.27

0.24

0.26

0.26

0.29

0.28

0.30

0.33

0.33

0.30
0.005

0.014

0.008

0.001

0.028

0.021

0.014

0.005

0.054

0.012

0.023

0.011

0.023

0.002

0.018

0.038

0.028

0.004

0.020

0.015

0.033

0.060

0.030

0.009

0.001

0.025

0.004

0.018

0.008

0.051

0.004

0.007

0.047

0.012

0.008

0.012

0.011

0.042

0.046

0.023

0.012

0.009

0.015

0.034

0.056

0.032
NE1

Okinawa

0.11

0.14

0.16

0.10

0.13

0.13

0.06

0.10

0.13

0.13

0.13

0.13

0.15

0.16

0.15

0.19

0.19

0.16

0.17

0.21

0.22

0.24

0.22

0.25

0.26

0.27

0.27

0.27

0.27

0.29

0.28

0.28

0.30

0.32

0.32

0.32

0.33

0.34

0.35

0.35

0.36

0.38

0.35

0.37

0.37

0.39
NW01

NW2

Okinawa

Okinawa

0.16

0.20

0.12

0.19

0.14

0.15

0.13

0.11

0.08

0.09

0.08

0.12

0.14

0.14

0.17

0.18

0.19

0.19

0.18

0.22

0.22

0.22

0.22

0.21

0.21

0.22

0.26

0.28

0.26

0.26

0.28

0.28

0.29

0.30

0.30

0.32

0.34

0.34

0.35

0.33

0.37

0.38

0.38

0.40

0.38

0.43

0.09

0.07

0.07

0.08

0.08

0.10

0.11

0.13

0.13

0.14

0.13

0.11

0.13

0.13

0.15

0.17

0.17

0.19

0.20

0.24

0.19

0.20

0.20

0.23

0.23

0.25

0.26

0.22

0.26

0.26

0.28

0.26

0.18

0.22

0.30

0.28

0.29

0.23

0.28

0.28

0.30

0.33 


\begin{tabular}{|c|c|c|c|c|c|}
\hline 0.35 & 0.32 & 0.040 & 0.37 & 0.40 & 0.32 \\
\hline 0.34 & 0.35 & 0.015 & 0.39 & 0.39 & 0.29 \\
\hline 0.26 & 0.30 & 0.066 & 0.39 & 0.40 & 0.31 \\
\hline 0.30 & 0.33 & 0.043 & 0.37 & 0.40 & 0.30 \\
\hline 0.29 & 0.33 & 0.063 & 0.39 & 0.40 & 0.31 \\
\hline 0.34 & 0.35 & 0.025 & 0.40 & 0.39 & 0.34 \\
\hline 0.36 & 0.37 & 0.016 & 0.39 & 0.24 & 0.36 \\
\hline 0.32 & 0.34 & 0.035 & 0.37 & 0.23 & 0.31 \\
\hline 0.36 & 0.35 & 0.013 & 0.36 & 0.33 & 0.34 \\
\hline 0.35 & 0.35 & 0.010 & 0.43 & 0.35 & 0.32 \\
\hline 0.37 & 0.36 & 0.004 & 0.40 & 0.43 & 0.30 \\
\hline 0.37 & 0.36 & 0.021 & 0.43 & 0.40 & 0.35 \\
\hline 0.39 & 0.35 & 0.053 & 0.39 & 0.44 & 0.35 \\
\hline 0.41 & 0.36 & 0.071 & 0.39 & 0.45 & 0.38 \\
\hline 0.42 & 0.40 & 0.037 & 0.34 & 0.43 & 0.33 \\
\hline 0.37 & 0.36 & 0.008 & 0.35 & 0.43 & 0.40 \\
\hline 0.43 & 0.41 & 0.025 & 0.40 & 0.43 & 0.39 \\
\hline 0.43 & 0.42 & 0.006 & 0.37 & 0.42 & 0.38 \\
\hline 0.42 & 0.41 & 0.001 & 0.37 & 0.42 & 0.40 \\
\hline 0.43 & 0.41 & 0.021 & 0.39 & 0.44 & 0.41 \\
\hline 0.45 & 0.44 & 0.013 & 0.42 & 0.41 & 0.39 \\
\hline 0.40 & 0.42 & 0.030 & 0.40 & 0.41 & 0.38 \\
\hline 0.42 & 0.45 & 0.035 & 0.38 & 0.43 & 0.35 \\
\hline 0.38 & 0.42 & 0.052 & 0.37 & 0.43 & 0.38 \\
\hline 0.38 & 0.41 & 0.037 & 0.40 & 0.40 & 0.37 \\
\hline 0.42 & 0.43 & 0.019 & 0.39 & 0.45 & 0.41 \\
\hline 0.39 & 0.41 & 0.035 & 0.37 & 0.49 & 0.37 \\
\hline 0.38 & 0.37 & 0.006 & 0.36 & 0.42 & 0.39 \\
\hline 0.33 & 0.36 & 0.044 & 0.38 & 0.39 & 0.39 \\
\hline 0.38 & 0.39 & 0.014 & 0.39 & 0.39 & 0.39 \\
\hline 0.38 & 0.40 & 0.025 & 0.36 & 0.39 & 0.43 \\
\hline 0.41 & 0.43 & 0.028 & 0.37 & 0.40 & 0.41 \\
\hline 0.39 & 0.41 & 0.023 & 0.40 & 0.43 & 0.43 \\
\hline 0.47 & 0.47 & 0.003 & 0.38 & 0.43 & 0.40 \\
\hline 0.45 & 0.44 & 0.013 & 0.38 & 0.46 & 0.42 \\
\hline 0.43 & 0.46 & 0.032 & 0.33 & 0.44 & 0.44 \\
\hline 0.47 & 0.46 & 0.012 & 0.38 & 0.44 & 0.40 \\
\hline 0.47 & 0.45 & 0.033 & 0.35 & 0.41 & 0.41 \\
\hline 0.45 & 0.47 & 0.023 & 0.37 & 0.38 & 0.39 \\
\hline 0.45 & 0.46 & 0.020 & 0.38 & 0.39 & 0.46 \\
\hline 0.44 & 0.46 & 0.032 & 0.41 & 0.36 & 0.42 \\
\hline 0.44 & 0.45 & 0.025 & 0.39 & 0.35 & 0.43 \\
\hline 0.46 & 0.48 & 0.022 & 0.39 & 0.36 & 0.43 \\
\hline 0.40 & 0.45 & 0.069 & 0.40 & 0.36 & 0.41 \\
\hline 0.42 & 0.45 & 0.045 & 0.41 & 0.34 & 0.45 \\
\hline 0.41 & 0.44 & 0.040 & 0.39 & 0.30 & 0.43 \\
\hline 0.39 & 0.45 & 0.081 & 0.42 & 0.32 & \\
\hline 0.44 & 0.45 & 0.014 & 0.40 & 0.32 & 0.44 \\
\hline 0.43 & 0.44 & 0.021 & 0.44 & 0.35 & 0.45 \\
\hline 0.47 & 0.48 & 0.004 & 0.41 & 0.37 & \\
\hline 0.45 & 0.45 & 0.001 & 0.42 & 0.37 & \\
\hline 0.46 & 0.47 & 0.011 & 0.41 & 0.33 & 0.46 \\
\hline
\end{tabular}




\begin{tabular}{|c|c|c|c|c|c|}
\hline 0.47 & 0.48 & 0.007 & 0.44 & 0.34 & 0.47 \\
\hline 0.47 & 0.47 & 0.006 & 0.46 & 0.35 & 0.45 \\
\hline 0.48 & 0.47 & 0.009 & 0.47 & 0.36 & 0.45 \\
\hline 0.47 & 0.47 & 0.004 & 0.44 & 0.35 & 0.42 \\
\hline 0.47 & 0.44 & 0.052 & 0.45 & 0.34 & 0.42 \\
\hline 0.48 & 0.46 & 0.020 & 0.39 & 0.34 & 0.45 \\
\hline 0.46 & 0.48 & 0.023 & 0.38 & 0.32 & 0.45 \\
\hline 0.46 & 0.47 & 0.013 & 0.36 & 0.30 & 0.42 \\
\hline 0.44 & 0.45 & 0.016 & 0.31 & 0.30 & 0.41 \\
\hline 0.43 & 0.47 & 0.050 & 0.26 & 0.33 & 0.41 \\
\hline 0.45 & 0.46 & 0.025 & 0.22 & 0.33 & 0.44 \\
\hline 0.44 & 0.45 & 0.016 & 0.26 & 0.31 & 0.42 \\
\hline 0.40 & 0.45 & 0.071 & 0.28 & 0.33 & 0.43 \\
\hline 0.40 & 0.46 & 0.074 & 0.33 & 0.35 & 0.41 \\
\hline 0.43 & 0.44 & 0.020 & 0.38 & 0.36 & 0.44 \\
\hline 0.33 & 0.39 & 0.093 & 0.33 & 0.39 & 0.45 \\
\hline 0.40 & 0.43 & 0.030 & 0.33 & 0.40 & 0.40 \\
\hline 0.37 & 0.42 & 0.059 & 0.31 & 0.37 & 0.44 \\
\hline 0.42 & 0.44 & 0.026 & 0.29 & 0.33 & 0.46 \\
\hline 0.41 & 0.45 & 0.054 & 0.30 & 0.41 & 0.47 \\
\hline 0.41 & 0.42 & 0.014 & 0.30 & 0.42 & 0.42 \\
\hline 0.40 & 0.42 & 0.030 & 0.36 & 0.44 & 0.45 \\
\hline 0.43 & 0.43 & 0.001 & 0.39 & 0.43 & 0.45 \\
\hline 0.37 & 0.38 & 0.014 & 0.37 & 0.44 & 0.45 \\
\hline 0.34 & 0.40 & 0.095 & 0.39 & 0.41 & 0.45 \\
\hline 0.34 & 0.40 & 0.081 & 0.36 & 0.41 & 0.46 \\
\hline 0.32 & 0.38 & 0.081 & 0.38 & 0.39 & 0.45 \\
\hline 0.34 & 0.40 & 0.093 & 0.40 & 0.41 & 0.43 \\
\hline 0.33 & 0.38 & 0.069 & 0.35 & 0.38 & 0.46 \\
\hline 0.37 & 0.41 & 0.057 & 0.39 & 0.38 & 0.44 \\
\hline 0.34 & 0.39 & 0.078 & 0.40 & 0.38 & 0.47 \\
\hline 0.29 & 0.35 & 0.088 & 0.40 & 0.41 & 0.47 \\
\hline 0.32 & 0.39 & 0.094 & 0.36 & 0.41 & 0.44 \\
\hline 0.32 & 0.38 & 0.076 & 0.36 & 0.41 & 0.46 \\
\hline 0.31 & 0.35 & 0.059 & 0.34 & 0.40 & 0.43 \\
\hline 0.36 & 0.37 & 0.019 & 0.40 & 0.40 & 0.43 \\
\hline 0.33 & 0.39 & 0.083 & 0.42 & 0.40 & 0.45 \\
\hline 0.30 & 0.35 & 0.079 & 0.43 & 0.40 & 0.43 \\
\hline 0.29 & 0.36 & 0.098 & 0.41 & 0.36 & 0.42 \\
\hline 0.32 & 0.33 & 0.020 & 0.38 & 0.35 & 0.43 \\
\hline 0.38 & 0.34 & 0.054 & 0.34 & 0.35 & 0.44 \\
\hline 0.38 & 0.38 & 0.006 & 0.30 & 0.32 & 0.37 \\
\hline 0.43 & 0.37 & 0.079 & 0.25 & 0.33 & 0.37 \\
\hline 0.40 & 0.39 & 0.015 & 0.32 & 0.32 & 0.42 \\
\hline 0.38 & 0.37 & 0.014 & 0.33 & 0.31 & 0.39 \\
\hline 0.38 & 0.39 & 0.017 & 0.35 & 0.33 & 0.37 \\
\hline 0.38 & 0.40 & 0.033 & 0.33 & 0.33 & 0.39 \\
\hline 0.38 & 0.39 & 0.013 & 0.32 & 0.33 & 0.39 \\
\hline 0.38 & 0.37 & 0.017 & 0.25 & 0.35 & 0.37 \\
\hline 0.31 & 0.34 & 0.047 & 0.24 & 0.35 & 0.44 \\
\hline 0.35 & 0.34 & 0.013 & 0.26 & 0.36 & 0.41 \\
\hline 0.34 & 0.33 & 0.023 & 0.26 & 0.36 & 0.39 \\
\hline
\end{tabular}




\begin{tabular}{|c|c|c|c|c|c|}
\hline 0.35 & 0.32 & 0.045 & 0.27 & 0.37 & 0.43 \\
\hline 0.34 & 0.31 & 0.042 & 0.30 & 0.36 & 0.41 \\
\hline 0.30 & 0.32 & 0.031 & 0.29 & 0.36 & 0.36 \\
\hline 0.32 & 0.31 & 0.020 & 0.30 & 0.39 & 0.36 \\
\hline 0.35 & 0.34 & 0.006 & 0.32 & 0.41 & 0.34 \\
\hline 0.32 & 0.35 & 0.041 & 0.40 & 0.43 & 0.33 \\
\hline 0.30 & 0.33 & 0.040 & 0.33 & 0.42 & 0.30 \\
\hline 0.25 & 0.29 & 0.062 & 0.29 & 0.45 & 0.32 \\
\hline 0.32 & 0.31 & 0.015 & 0.27 & 0.43 & 0.31 \\
\hline 0.25 & 0.23 & 0.033 & 0.31 & 0.45 & 0.28 \\
\hline 0.22 & 0.20 & 0.027 & 0.33 & 0.47 & 0.25 \\
\hline 0.22 & 0.19 & 0.040 & 0.35 & 0.42 & 0.24 \\
\hline 0.23 & 0.19 & 0.057 & 0.35 & 0.40 & 0.25 \\
\hline 0.27 & 0.22 & 0.074 & 0.42 & 0.37 & 0.24 \\
\hline 0.26 & 0.21 & 0.067 & 0.40 & 0.34 & 0.25 \\
\hline 0.22 & 0.17 & 0.066 & & 0.33 & 0.21 \\
\hline 0.29 & 0.21 & 0.110 & & 0.28 & 0.22 \\
\hline 0.28 & 0.24 & 0.059 & & 0.24 & 0.22 \\
\hline 0.26 & 0.25 & 0.009 & & 0.20 & 0.19 \\
\hline 0.25 & 0.23 & 0.033 & & 0.27 & 0.12 \\
\hline 0.26 & 0.23 & 0.052 & & 0.26 & 0.10 \\
\hline 0.30 & 0.24 & 0.080 & & 0.10 & 0.12 \\
\hline 0.27 & 0.26 & 0.013 & & 0.12 & 0.16 \\
\hline 0.25 & 0.27 & 0.025 & & 0.08 & \\
\hline 0.31 & 0.30 & 0.010 & & 0.09 & 0.07 \\
\hline 0.34 & 0.30 & 0.052 & & 0.07 & 0.06 \\
\hline
\end{tabular}

0.34

$0.29 \quad 0.062$

$0.28 \quad 0.023$

$0.27 \quad 0.029$

$0.27 \quad 0.060$

$\begin{array}{lll}0.26 & 0.28 & 0.033 \\ 0.24 & 0.25 & 0.026\end{array}$

$\begin{array}{lll}0.23 & 0.27 & 0.049\end{array}$

$\begin{array}{lll}0.26 & 0.30 & 0.063\end{array}$

$\begin{array}{lll}0.30 & 0.29 & 0.016\end{array}$

$\begin{array}{lll}0.31 & 0.33 & 0.028\end{array}$

$\begin{array}{lll}0.31 & 0.36 & 0.069\end{array}$

$\begin{array}{lll}0.29 & 0.30 & 0.021\end{array}$

$\begin{array}{lll}0.25 & 0.28 & 0.050\end{array}$

$\begin{array}{lll}0.30 & 0.34 & 0.064\end{array}$

$\begin{array}{lll}0.23 & 0.30 & 0.103\end{array}$

$\begin{array}{lll}0.19 & 0.28 & 0.133\end{array}$

$\begin{array}{lll}0.20 & 0.27 & 0.094\end{array}$

$\begin{array}{lll}0.19 & 0.30 & 0.160\end{array}$

$\begin{array}{lll}0.22 & 0.31 & 0.123\end{array}$

$\begin{array}{lll}0.22 & 0.30 & 0.104\end{array}$

$\begin{array}{lll}0.25 & 0.28 & 0.050\end{array}$

$\begin{array}{lll}0.28 & 0.25 & 0.033\end{array}$

$\begin{array}{lll}0.29 & 0.29 & 0.008\end{array}$

$\begin{array}{lll}0.29 & 0.32 & 0.042\end{array}$

$\begin{array}{lll}0.29 & 0.35 & 0.077\end{array}$

$\begin{array}{lll}0.26 & 0.28 & 0.029\end{array}$ 


$\begin{array}{lll}0.29 & 0.27 & 0.022 \\ 0.26 & 0.25 & 0.004 \\ 0.28 & 0.27 & 0.014 \\ 0.19 & 0.21 & 0.035 \\ 0.18 & 0.19 & 0.015 \\ 0.17 & 0.20 & 0.035 \\ 0.20 & 0.21 & 0.023 \\ 0.24 & 0.25 & 0.016 \\ 0.27 & 0.23 & 0.048 \\ 0.28 & 0.25 & 0.048 \\ 0.24 & 0.23 & 0.023 \\ 0.24 & 0.23 & 0.021 \\ 0.20 & 0.22 & 0.027 \\ 0.19 & 0.16 & 0.037 \\ 0.26 & 0.19 & 0.091 \\ 0.28 & 0.19 & 0.127 \\ & 0.13 & \\ & 0.09 & \\ & 0.08 & \\ & 0.08 & \\ & 0.10 & \\ & 0.11 & \end{array}$


Sepia pharaonis

\section{NW5}

Okinawa

0.13

0.13

0.12

0.14

0.14

0.14

0.15

0.15

0.15

0.11

0.11

0.09

0.11

0.11

0.10

0.13

0.12

0.11

0.15

0.16

0.17

0.18

0.18

0.16

0.17

0.18

0.17

0.19

0.23

0.25

0.25

0.28

0.29

0.32

0.30

0.33

0.33

0.33

0.32

0.35

0.37

0.37

0.35

0.37

0.35

0.36
NW4

Okinawa

0.18

0.19

0.17

0.14

0.13

0.15

0.12

0.13

0.10

0.13

0.09

0.13

0.18

0.16

0.17

0.17

0.15

0.20

0.19

0.22

0.22

0.23

0.22

0.25

0.25

0.21

0.22

0.26

0.26

0.25

0.27

0.29

0.32

0.29

0.32

0.29

0.32

0.31

0.32

0.33

0.32

0.30

0.31

0.35

0.34

0.34
NA03

Okinawa

0.10

0.14

0.11

0.13

0.14

0.13

0.07

0.08

0.07

0.10

0.09

0.11

0.14

0.14

0.15

0.18

0.17

0.15

0.17

0.18

0.15

0.17

0.14

0.14

0.17

0.24

0.22

0.24

0.23

0.26

0.26

0.28

0.28

0.27

0.26

0.27

0.30

0.28

0.28

0.31

0.30

0.32

0.31

0.32

0.31

0.33

\section{NE03}

Okinawa

0.15

0.14

0.13

0.10

0.06

0.10

0.09

0.06

0.10

0.09

0.11

0.11

0.10

0.09

0.09

0.09

0.12

0.14

0.13

0.15

0.17

0.16

0.15

0.18

0.16

0.20

0.20

0.20

0.17

0.11

0.21

0.22

0.24

0.23

0.28

0.26

0.27

0.25

0.29

0.34

0.33

0.30

0.30

0.32

0.33
NE04

Okinawa

0.12

0.16

0.15

0.16

0.18

0.12

0.10

0.14

0.18

0.08

0.12

0.09

0.13

0.19

0.18

0.19

0.17

0.15

0.14

0.17

0.17

0.21

0.18

0.18

0.24

0.24

0.23

0.27

0.30

0.29

0.29

0.29

0.27

0.34

0.35

0.32

0.37

0.35

0.37

0.39

0.38

0.38

0.38

0.39

0.40

0.44

NW02

average

Okinawa

0.17

0.13

0.14

0.14

0.17

0.13

0.17

0.13

0.16

0.13

0.12

0.13

0.15

0.11

0.11

0.10

0.11

0.07

0.11

0.11

0.10

0.11

0.11

0.14

0.16

0.14

0.14

0.14

0.16

0.14

0.16

0.15

0.15

0.14

0.16

0.16

0.17

0.19

0.19

0.19

0.20 


\begin{tabular}{|c|c|c|c|c|c|c|}
\hline 0.42 & 0.34 & 0.33 & 0.34 & 0.40 & 0.38 & 0.37 \\
\hline 0.35 & 0.31 & 0.35 & 0.33 & 0.41 & 0.43 & 0.36 \\
\hline 0.37 & 0.32 & 0.34 & 0.32 & 0.45 & 0.38 & 0.37 \\
\hline 0.37 & 0.37 & 0.33 & 0.36 & 0.42 & 0.36 & 0.36 \\
\hline 0.38 & 0.33 & 0.39 & 0.31 & 0.42 & 0.42 & 0.37 \\
\hline 0.39 & 0.31 & 0.31 & 0.32 & 0.37 & 0.40 & 0.36 \\
\hline 0.40 & 0.34 & 0.36 & 0.37 & 0.45 & 0.37 & 0.36 \\
\hline 0.36 & 0.33 & 0.37 & 0.34 & 0.42 & 0.42 & 0.35 \\
\hline 0.33 & 0.36 & 0.37 & 0.31 & 0.44 & 0.39 & 0.36 \\
\hline 0.41 & 0.34 & 0.36 & 0.36 & 0.44 & 0.41 & 0.38 \\
\hline 0.41 & 0.33 & 0.37 & 0.31 & 0.45 & 0.41 & 0.38 \\
\hline 0.42 & 0.38 & 0.36 & 0.35 & 0.48 & 0.41 & 0.40 \\
\hline 0.43 & 0.39 & 0.36 & 0.35 & 0.41 & 0.41 & 0.39 \\
\hline 0.43 & 0.38 & 0.39 & 0.34 & 0.50 & 0.40 & 0.41 \\
\hline 0.41 & 0.36 & 0.34 & 0.33 & 0.42 & 0.43 & 0.38 \\
\hline 0.40 & 0.41 & 0.38 & 0.34 & 0.47 & 0.46 & 0.40 \\
\hline 0.37 & 0.39 & 0.37 & 0.33 & 0.46 & 0.46 & 0.40 \\
\hline 0.37 & 0.36 & 0.36 & 0.34 & 0.42 & 0.45 & 0.39 \\
\hline 0.45 & 0.34 & 0.39 & 0.34 & 0.44 & 0.46 & 0.40 \\
\hline 0.37 & 0.33 & 0.37 & 0.36 & 0.48 & 0.43 & 0.40 \\
\hline 0.30 & 0.35 & 0.39 & 0.36 & 0.43 & 0.42 & 0.39 \\
\hline 0.47 & 0.35 & 0.38 & 0.38 & 0.45 & 0.41 & 0.40 \\
\hline 0.39 & 0.40 & 0.36 & 0.37 & 0.44 & 0.40 & 0.39 \\
\hline 0.47 & 0.38 & 0.36 & 0.37 & 0.45 & 0.35 & 0.40 \\
\hline 0.49 & 0.42 & 0.32 & 0.37 & 0.42 & 0.43 & 0.40 \\
\hline 0.46 & 0.44 & 0.30 & 0.33 & 0.42 & 0.44 & 0.40 \\
\hline 0.47 & 0.43 & 0.30 & 0.38 & 0.42 & 0.39 & 0.40 \\
\hline 0.49 & 0.41 & 0.29 & 0.37 & 0.42 & 0.42 & 0.40 \\
\hline 0.45 & 0.45 & 0.09 & 0.37 & 0.44 & 0.44 & 0.38 \\
\hline 0.42 & 0.39 & 0.11 & 0.39 & 0.39 & 0.45 & 0.37 \\
\hline 0.39 & 0.31 & 0.21 & 0.37 & 0.46 & 0.43 & 0.37 \\
\hline 0.31 & 0.29 & 0.31 & 0.35 & 0.40 & 0.40 & 0.36 \\
\hline 0.29 & 0.26 & 0.33 & 0.41 & 0.41 & 0.42 & 0.38 \\
\hline 0.33 & 0.30 & 0.34 & 0.37 & 0.39 & 0.37 & 0.37 \\
\hline 0.35 & 0.35 & 0.38 & 0.39 & 0.47 & 0.42 & 0.40 \\
\hline 0.34 & 0.38 & 0.34 & 0.42 & 0.48 & 0.31 & 0.39 \\
\hline 0.34 & 0.37 & 0.33 & 0.41 & 0.48 & 0.31 & 0.38 \\
\hline 0.34 & 0.37 & 0.36 & 0.39 & 0.46 & 0.28 & 0.37 \\
\hline 0.32 & 0.40 & 0.40 & 0.37 & 0.46 & 0.32 & 0.38 \\
\hline 0.31 & 0.39 & 0.42 & 0.39 & 0.43 & 0.32 & 0.39 \\
\hline 0.35 & 0.41 & 0.40 & 0.35 & 0.46 & 0.39 & 0.39 \\
\hline 0.32 & 0.39 & 0.43 & 0.35 & 0.47 & 0.37 & 0.39 \\
\hline 0.38 & 0.39 & 0.44 & 0.37 & 0.50 & 0.39 & 0.40 \\
\hline 0.33 & 0.41 & 0.44 & 0.37 & 0.42 & 0.41 & 0.40 \\
\hline 0.34 & 0.39 & 0.42 & 0.38 & 0.49 & 0.40 & 0.40 \\
\hline 0.35 & 0.40 & 0.41 & 0.37 & 0.47 & 0.42 & 0.39 \\
\hline 0.39 & 0.40 & 0.40 & 0.34 & 0.47 & 0.44 & 0.40 \\
\hline 0.41 & 0.38 & 0.41 & 0.39 & 0.48 & 0.44 & 0.41 \\
\hline 0.39 & 0.37 & 0.36 & 0.37 & 0.51 & 0.44 & 0.41 \\
\hline 0.40 & 0.38 & 0.42 & 0.37 & 0.51 & 0.45 & 0.41 \\
\hline 0.39 & 0.39 & 0.43 & 0.35 & 0.44 & 0.45 & 0.41 \\
\hline 0.42 & 0.38 & 0.44 & 0.33 & 0.42 & 0.44 & \\
\hline
\end{tabular}




\begin{tabular}{|c|c|c|c|c|c|c|}
\hline 0.41 & 0.36 & 0.38 & 0.33 & 0.50 & 0.45 & 0.41 \\
\hline 0.41 & 0.37 & 0.38 & 0.38 & 0.45 & 0.42 & 0.41 \\
\hline 0.39 & 0.37 & 0.43 & 0.34 & 0.41 & 0.39 & 0.40 \\
\hline 0.41 & 0.37 & 0.38 & 0.31 & 0.44 & 0.40 & 0.39 \\
\hline 0.43 & 0.38 & 0.38 & 0.33 & 0.43 & 0.40 & 0.40 \\
\hline 0.45 & 0.36 & 0.37 & 0.34 & 0.47 & 0.36 & 0.39 \\
\hline 0.45 & 0.37 & 0.38 & 0.35 & 0.44 & 0.35 & 0.39 \\
\hline 0.46 & 0.39 & 0.32 & 0.34 & 0.41 & 0.34 & 0.37 \\
\hline 0.44 & 0.40 & 0.35 & 0.37 & 0.43 & 0.36 & 0.37 \\
\hline 0.44 & 0.38 & 0.37 & 0.35 & 0.45 & 0.32 & 0.37 \\
\hline 0.46 & 0.36 & 0.30 & 0.36 & 0.37 & 0.33 & 0.35 \\
\hline 0.41 & 0.36 & 0.28 & 0.34 & 0.37 & 0.31 & 0.34 \\
\hline 0.46 & 0.39 & 0.28 & 0.34 & 0.42 & 0.35 & 0.36 \\
\hline 0.43 & 0.38 & 0.25 & 0.36 & 0.44 & 0.34 & 0.36 \\
\hline 0.42 & 0.37 & 0.25 & 0.30 & 0.42 & 0.34 & 0.36 \\
\hline 0.41 & 0.39 & 0.24 & 0.28 & 0.49 & 0.36 & 0.37 \\
\hline 0.43 & 0.38 & 0.26 & 0.29 & 0.40 & 0.38 & 0.36 \\
\hline 0.44 & 0.37 & 0.28 & 0.34 & 0.40 & 0.37 & 0.37 \\
\hline 0.39 & 0.38 & 0.30 & 0.33 & 0.40 & 0.39 & 0.36 \\
\hline 0.37 & 0.41 & 0.31 & 0.33 & 0.32 & 0.45 & 0.37 \\
\hline 0.36 & 0.38 & 0.34 & 0.39 & 0.36 & 0.42 & 0.38 \\
\hline 0.39 & 0.37 & 0.31 & 0.35 & 0.36 & 0.39 & 0.38 \\
\hline 0.39 & 0.36 & 0.31 & 0.34 & 0.41 & 0.42 & 0.39 \\
\hline 0.40 & 0.34 & 0.33 & 0.32 & 0.36 & 0.42 & 0.38 \\
\hline 0.38 & 0.33 & 0.28 & 0.35 & 0.35 & 0.43 & 0.37 \\
\hline 0.42 & 0.38 & 0.35 & 0.35 & 0.36 & 0.46 & 0.39 \\
\hline 0.39 & 0.38 & 0.30 & 0.36 & 0.38 & 0.38 & 0.38 \\
\hline 0.33 & 0.37 & 0.32 & 0.33 & 0.36 & 0.43 & 0.37 \\
\hline 0.38 & 0.40 & 0.28 & 0.35 & 0.39 & 0.41 & 0.38 \\
\hline 0.38 & 0.32 & 0.29 & 0.33 & 0.39 & 0.45 & 0.37 \\
\hline 0.43 & 0.33 & 0.30 & 0.32 & 0.36 & 0.38 & 0.37 \\
\hline 0.41 & 0.34 & 0.35 & 0.32 & 0.34 & 0.40 & 0.38 \\
\hline 0.42 & 0.33 & 0.34 & 0.31 & 0.36 & 0.38 & 0.37 \\
\hline 0.38 & 0.31 & 0.32 & 0.29 & 0.36 & 0.39 & 0.37 \\
\hline 0.36 & 0.37 & 0.29 & 0.33 & 0.40 & 0.36 & 0.36 \\
\hline 0.34 & 0.40 & 0.29 & 0.32 & 0.42 & 0.44 & 0.38 \\
\hline 0.34 & 0.36 & 0.32 & 0.33 & 0.40 & 0.45 & 0.39 \\
\hline 0.37 & 0.36 & 0.33 & 0.32 & 0.42 & 0.40 & 0.38 \\
\hline 0.40 & 0.33 & 0.30 & 0.35 & 0.45 & 0.42 & 0.38 \\
\hline 0.45 & 0.35 & 0.34 & 0.35 & 0.46 & 0.42 & 0.39 \\
\hline 0.41 & 0.41 & 0.31 & 0.37 & 0.46 & 0.44 & 0.39 \\
\hline 0.41 & 0.41 & 0.34 & 0.39 & 0.39 & 0.39 & 0.37 \\
\hline 0.40 & 0.45 & 0.33 & 0.38 & 0.40 & 0.39 & 0.37 \\
\hline 0.37 & 0.44 & 0.34 & 0.42 & 0.43 & 0.37 & 0.38 \\
\hline 0.39 & 0.42 & 0.38 & 0.39 & 0.48 & 0.39 & 0.39 \\
\hline 0.40 & 0.42 & 0.36 & 0.38 & 0.52 & 0.39 & 0.39 \\
\hline 0.39 & 0.42 & 0.41 & 0.38 & 0.50 & 0.41 & 0.40 \\
\hline 0.34 & 0.44 & 0.38 & 0.35 & 0.47 & 0.41 & 0.38 \\
\hline 0.35 & 0.42 & 0.37 & 0.39 & 0.44 & 0.43 & 0.37 \\
\hline 0.35 & 0.43 & 0.33 & 0.38 & 0.53 & 0.41 & 0.38 \\
\hline 0.33 & 0.39 & 0.36 & 0.44 & 0.46 & 0.39 & 0.38 \\
\hline 0.33 & 0.39 & 0.29 & 0.41 & 0.50 & 0.39 & \\
\hline
\end{tabular}




\begin{tabular}{|c|c|c|c|c|c|c|}
\hline 0.33 & 0.36 & 0.32 & 0.37 & 0.46 & 0.41 & 0.37 \\
\hline 0.34 & 0.39 & 0.33 & 0.35 & 0.47 & 0.38 & 0.37 \\
\hline 0.31 & 0.43 & 0.39 & 0.38 & 0.49 & 0.36 & 0.37 \\
\hline 0.35 & 0.46 & 0.30 & 0.37 & 0.50 & 0.31 & 0.37 \\
\hline 0.35 & 0.46 & 0.32 & 0.39 & 0.49 & 0.34 & 0.38 \\
\hline 0.32 & 0.46 & 0.39 & 0.39 & 0.51 & 0.33 & 0.39 \\
\hline 0.31 & 0.43 & 0.36 & 0.36 & 0.47 & 0.33 & 0.37 \\
\hline 0.33 & 0.40 & 0.32 & 0.35 & 0.46 & 0.30 & 0.36 \\
\hline 0.36 & 0.40 & 0.36 & 0.34 & 0.47 & 0.36 & 0.37 \\
\hline 0.36 & 0.40 & 0.34 & 0.32 & 0.46 & 0.36 & 0.36 \\
\hline 0.36 & 0.43 & 0.29 & 0.35 & 0.46 & 0.32 & 0.36 \\
\hline 0.38 & 0.42 & 0.29 & 0.32 & 0.51 & 0.33 & 0.36 \\
\hline 0.39 & 0.44 & 0.32 & 0.28 & 0.50 & 0.34 & 0.36 \\
\hline 0.38 & 0.40 & 0.32 & 0.32 & 0.49 & 0.35 & 0.37 \\
\hline 0.34 & 0.37 & 0.32 & 0.35 & 0.50 & 0.37 & 0.36 \\
\hline 0.36 & 0.35 & 0.33 & 0.35 & 0.46 & 0.34 & 0.34 \\
\hline 0.38 & 0.33 & 0.27 & & 0.45 & 0.31 & 0.32 \\
\hline 0.34 & 0.31 & 0.25 & & 0.45 & 0.25 & 0.29 \\
\hline 0.35 & 0.31 & 0.25 & & 0.41 & 0.23 & 0.28 \\
\hline \multirow[t]{33}{*}{0.38} & 0.31 & 0.21 & & 0.43 & 0.19 & 0.27 \\
\hline & 0.29 & 0.20 & & 0.39 & 0.14 & 0.23 \\
\hline & 0.29 & 0.25 & & 0.39 & 0.17 & 0.22 \\
\hline & 0.30 & 0.21 & & 0.31 & 0.18 & 0.21 \\
\hline & 0.30 & 0.26 & & 0.26 & & 0.2 \\
\hline & 0.28 & 0.22 & & 0.23 & & 0.18 \\
\hline & 0.29 & 0.24 & & 0.25 & & 0.18 \\
\hline & 0.26 & 0.23 & & 0.25 & & 0.25 \\
\hline & 0.24 & 0.23 & & 0.19 & & 0.22 \\
\hline & 0.24 & 0.17 & & 0.18 & & 0.19 \\
\hline & 0.20 & 0.19 & & 0.16 & & 0.18 \\
\hline & 0.19 & 0.20 & & 0.17 & & 0.19 \\
\hline & 0.18 & 0.21 & & & & 0.19 \\
\hline & & 0.21 & & & & 0.21 \\
\hline & & 0.24 & & & & 0.24 \\
\hline & & 0.22 & & & & 0.22 \\
\hline & & 0.23 & & & & 0.23 \\
\hline & & 0.27 & & & & 0.27 \\
\hline & & 0.22 & & & & 0.22 \\
\hline & & 0.20 & & & & 0.20 \\
\hline & & 0.23 & & & & 0.23 \\
\hline & & 0.17 & & & & 0.17 \\
\hline & & 0.16 & & & & 0.16 \\
\hline & & 0.15 & & & & 0.15 \\
\hline & & 0.17 & & & & 0.17 \\
\hline & & 0.16 & & & & 0.16 \\
\hline & & 0.13 & & & & 0.13 \\
\hline & & 0.18 & & & & 0.18 \\
\hline & & 0.13 & & & & 0.13 \\
\hline & & 0.11 & & & & 0.11 \\
\hline & & 0.13 & & & & 0.13 \\
\hline & & 0.11 & & & & 0.11 \\
\hline & & 0.09 & & & & \\
\hline
\end{tabular}




\begin{tabular}{|c|c|c|c|c|c|}
\hline standard & SJ1-3 & SJ1-7 & SJ1-10 & SJ2-1 & SJ2-2 \\
\hline deviation & $\begin{array}{c}\text { Sea of } \\
\text { Harima }\end{array}$ & $\begin{array}{c}\text { Sea of } \\
\text { Harima }\end{array}$ & $\begin{array}{c}\text { Sea of } \\
\text { Harima }\end{array}$ & $\begin{array}{c}\text { Sea of } \\
\text { Harima }\end{array}$ & $\begin{array}{c}\text { Sea of } \\
\text { Harima }\end{array}$ \\
\hline 0.030 & & & 0.14 & & 0.18 \\
\hline 0.035 & & & 0.16 & & 0.18 \\
\hline 0.031 & & & 0.23 & & 0.20 \\
\hline 0.033 & & & 0.16 & & 0.16 \\
\hline 0.033 & & & 0.13 & & 0.13 \\
\hline 0.018 & & 0.16 & 0.12 & & 0.10 \\
\hline 0.029 & & 0.16 & 0.14 & & 0.07 \\
\hline 0.027 & & 0.15 & 0.06 & & 0.10 \\
\hline 0.033 & & 0.23 & 0.09 & & 0.11 \\
\hline 0.022 & & 0.22 & 0.11 & & 0.10 \\
\hline 0.018 & & & 0.10 & & 0.12 \\
\hline 0.014 & & & 0.08 & & 0.09 \\
\hline 0.020 & & & 0.10 & & 0.09 \\
\hline 0.025 & & & 0.09 & & 0.11 \\
\hline 0.028 & & & 0.06 & & 0.15 \\
\hline 0.031 & & & 0.10 & 0.27 & 0.11 \\
\hline 0.031 & & 0.23 & 0.11 & 0.25 & 0.09 \\
\hline 0.029 & & 0.23 & 0.14 & 0.24 & 0.15 \\
\hline 0.022 & & 0.22 & 0.11 & 0.28 & 0.12 \\
\hline 0.034 & & 0.30 & 0.11 & 0.28 & 0.21 \\
\hline 0.026 & 0.18 & & 0.14 & 0.21 & 0.22 \\
\hline 0.026 & 0.18 & & 0.18 & 0.30 & 0.20 \\
\hline 0.026 & 0.18 & & 0.13 & 0.28 & 0.25 \\
\hline 0.040 & 0.16 & & 0.18 & 0.32 & 0.26 \\
\hline 0.033 & 0.15 & 0.27 & 0.19 & 0.33 & 0.25 \\
\hline 0.037 & 0.24 & 0.27 & 0.18 & 0.32 & 0.23 \\
\hline 0.030 & 0.20 & 0.30 & 0.21 & 0.32 & 0.26 \\
\hline 0.030 & 0.21 & 0.32 & 0.19 & 0.34 & 0.27 \\
\hline 0.027 & 0.20 & 0.32 & 0.14 & 0.30 & 0.21 \\
\hline 0.034 & 0.23 & 0.30 & 0.21 & 0.34 & 0.21 \\
\hline 0.054 & 0.23 & 0.33 & 0.22 & 0.29 & 0.25 \\
\hline 0.023 & 0.24 & 0.33 & 0.24 & 0.35 & 0.25 \\
\hline 0.039 & 0.23 & 0.34 & 0.20 & 0.31 & 0.30 \\
\hline 0.037 & 0.21 & 0.35 & 0.23 & 0.32 & 0.29 \\
\hline 0.033 & 0.20 & 0.35 & 0.23 & 0.35 & 0.29 \\
\hline 0.022 & 0.29 & 0.37 & 0.21 & 0.36 & 0.24 \\
\hline 0.029 & 0.27 & 0.38 & 0.24 & 0.39 & 0.29 \\
\hline 0.037 & 0.30 & 0.38 & 0.22 & 0.35 & 0.30 \\
\hline 0.037 & 0.28 & 0.37 & 0.29 & 0.37 & 0.32 \\
\hline 0.033 & 0.32 & 0.37 & 0.23 & 0.27 & 0.32 \\
\hline 0.027 & 0.27 & 0.37 & 0.24 & 0.35 & 0.37 \\
\hline 0.029 & 0.32 & 0.38 & 0.32 & 0.32 & 0.36 \\
\hline 0.037 & 0.27 & 0.38 & 0.31 & 0.29 & 0.32 \\
\hline 0.036 & 0.28 & 0.39 & 0.29 & 0.29 & 0.34 \\
\hline 0.033 & 0.31 & 0.36 & 0.31 & 0.33 & 0.32 \\
\hline 0.038 & 0.29 & 0.34 & 0.30 & 0.29 & 0.33 \\
\hline
\end{tabular}




\begin{tabular}{|c|c|c|c|c|c|}
\hline 0.034 & 0.37 & 0.35 & 0.29 & 0.30 & 0.30 \\
\hline 0.047 & 0.38 & 0.36 & 0.25 & 0.38 & 0.33 \\
\hline 0.043 & 0.33 & 0.32 & 0.29 & 0.33 & 0.38 \\
\hline 0.032 & 0.33 & 0.37 & 0.30 & 0.28 & 0.36 \\
\hline 0.043 & 0.35 & 0.37 & 0.27 & 0.43 & 0.34 \\
\hline 0.035 & 0.32 & 0.46 & 0.28 & 0.29 & 0.38 \\
\hline 0.053 & 0.31 & 0.32 & 0.27 & 0.45 & 0.25 \\
\hline 0.053 & 0.32 & 0.37 & 0.27 & 0.34 & 0.37 \\
\hline 0.038 & 0.38 & 0.37 & 0.30 & 0.35 & 0.30 \\
\hline 0.040 & 0.33 & 0.39 & 0.30 & 0.41 & 0.38 \\
\hline 0.050 & 0.38 & 0.43 & 0.30 & 0.35 & 0.40 \\
\hline 0.041 & 0.38 & 0.37 & 0.28 & 0.37 & 0.32 \\
\hline 0.032 & 0.33 & 0.37 & 0.32 & 0.40 & 0.36 \\
\hline 0.045 & 0.42 & 0.38 & 0.31 & 0.37 & 0.38 \\
\hline 0.042 & 0.38 & 0.36 & 0.35 & 0.33 & 0.38 \\
\hline 0.042 & 0.39 & 0.40 & 0.29 & 0.35 & 0.35 \\
\hline 0.039 & 0.30 & 0.43 & 0.28 & 0.35 & 0.42 \\
\hline 0.034 & 0.37 & 0.46 & 0.28 & 0.37 & 0.36 \\
\hline 0.043 & 0.41 & 0.37 & 0.30 & 0.32 & 0.36 \\
\hline 0.045 & 0.36 & 0.41 & 0.30 & 0.31 & 0.36 \\
\hline 0.040 & 0.39 & 0.43 & 0.31 & 0.34 & 0.39 \\
\hline 0.034 & 0.34 & 0.38 & 0.33 & 0.34 & 0.35 \\
\hline 0.028 & 0.42 & 0.45 & 0.31 & 0.33 & 0.36 \\
\hline 0.041 & 0.39 & 0.40 & 0.32 & 0.36 & 0.34 \\
\hline 0.046 & 0.37 & 0.36 & 0.33 & 0.37 & 0.38 \\
\hline 0.053 & 0.38 & 0.36 & 0.33 & 0.37 & 0.35 \\
\hline 0.054 & 0.45 & 0.40 & 0.33 & 0.30 & 0.35 \\
\hline 0.050 & 0.33 & 0.38 & 0.30 & 0.33 & 0.33 \\
\hline 0.106 & 0.39 & 0.37 & 0.33 & 0.27 & 0.38 \\
\hline 0.095 & 0.37 & 0.39 & 0.32 & 0.39 & 0.35 \\
\hline 0.071 & 0.40 & 0.38 & 0.34 & 0.29 & 0.34 \\
\hline 0.044 & 0.39 & 0.31 & 0.31 & 0.32 & 0.37 \\
\hline 0.060 & 0.35 & 0.38 & 0.35 & 0.32 & 0.34 \\
\hline 0.035 & 0.41 & 0.36 & 0.32 & 0.29 & 0.34 \\
\hline 0.041 & 0.34 & 0.38 & 0.34 & 0.32 & 0.39 \\
\hline 0.057 & 0.37 & 0.34 & 0.32 & 0.28 & 0.34 \\
\hline 0.051 & 0.35 & 0.33 & 0.34 & 0.25 & 0.36 \\
\hline 0.048 & 0.36 & 0.32 & 0.35 & 0.26 & 0.37 \\
\hline 0.040 & 0.36 & 0.31 & 0.30 & 0.18 & 0.31 \\
\hline 0.046 & 0.36 & 0.32 & 0.45 & 0.23 & 0.30 \\
\hline 0.034 & 0.40 & 0.23 & 0.32 & 0.33 & 0.37 \\
\hline 0.045 & 0.38 & 0.26 & 0.29 & 0.27 & 0.38 \\
\hline 0.042 & 0.37 & 0.21 & 0.33 & 0.32 & 0.32 \\
\hline 0.034 & 0.36 & 0.16 & 0.32 & 0.32 & 0.32 \\
\hline 0.045 & 0.38 & 0.21 & 0.35 & 0.31 & 0.35 \\
\hline 0.047 & 0.35 & 0.19 & 0.29 & 0.31 & 0.35 \\
\hline 0.045 & 0.34 & 0.18 & 0.34 & 0.31 & 0.34 \\
\hline 0.041 & 0.33 & 0.20 & 0.34 & 0.33 & 0.33 \\
\hline 0.050 & 0.43 & 0.25 & 0.32 & 0.29 & 0.36 \\
\hline 0.041 & 0.37 & 0.26 & 0.33 & 0.28 & 0.34 \\
\hline 0.032 & 0.34 & 0.24 & 0.35 & 0.29 & 0.34 \\
\hline 0.045 & 0.41 & 0.20 & 0.33 & 0.35 & 0.37 \\
\hline
\end{tabular}




\begin{tabular}{|c|c|c|c|c|c|}
\hline 0.055 & 0.41 & 0.23 & 0.34 & 0.34 & 0.33 \\
\hline 0.038 & 0.39 & 0.20 & 0.33 & 0.34 & 0.36 \\
\hline 0.041 & 0.34 & 0.21 & 0.30 & 0.32 & 0.35 \\
\hline 0.041 & 0.34 & 0.24 & 0.33 & 0.29 & 0.36 \\
\hline 0.039 & 0.37 & 0.24 & 0.36 & 0.27 & 0.35 \\
\hline 0.049 & 0.43 & 0.27 & 0.32 & 0.24 & 0.36 \\
\hline 0.046 & 0.35 & 0.24 & 0.35 & 0.33 & 0.36 \\
\hline 0.048 & 0.36 & 0.27 & 0.31 & 0.19 & 0.31 \\
\hline 0.047 & 0.36 & 0.27 & 0.35 & 0.31 & 0.39 \\
\hline 0.056 & 0.40 & 0.30 & 0.32 & 0.34 & 0.36 \\
\hline 0.069 & 0.41 & 0.27 & 0.39 & 0.36 & 0.36 \\
\hline 0.052 & 0.43 & 0.35 & 0.29 & 0.42 & 0.37 \\
\hline 0.060 & 0.34 & 0.38 & 0.35 & 0.36 & 0.37 \\
\hline 0.056 & 0.46 & 0.39 & 0.37 & 0.40 & 0.41 \\
\hline 0.060 & 0.39 & 0.43 & 0.34 & 0.45 & 0.38 \\
\hline 0.073 & 0.34 & 0.39 & 0.35 & 0.46 & 0.41 \\
\hline 0.054 & 0.46 & 0.38 & 0.31 & 0.42 & 0.37 \\
\hline 0.049 & 0.37 & 0.40 & 0.38 & 0.46 & 0.39 \\
\hline 0.051 & 0.43 & 0.39 & 0.31 & 0.47 & 0.37 \\
\hline 0.059 & 0.38 & 0.37 & 0.35 & 0.45 & 0.35 \\
\hline 0.039 & 0.36 & 0.40 & 0.40 & 0.41 & 0.42 \\
\hline 0.041 & 0.44 & & 0.35 & 0.37 & 0.35 \\
\hline 0.042 & 0.37 & & 0.37 & 0.34 & 0.40 \\
\hline 0.045 & 0.40 & & 0.32 & 0.25 & 0.39 \\
\hline 0.049 & 0.48 & & 0.36 & 0.26 & 0.37 \\
\hline 0.043 & 0.36 & & 0.29 & 0.17 & 0.40 \\
\hline 0.037 & 0.41 & & 0.38 & 0.23 & 0.38 \\
\hline 0.039 & 0.39 & & 0.38 & 0.20 & 0.41 \\
\hline 0.049 & 0.24 & & 0.39 & 0.18 & 0.39 \\
\hline 0.050 & 0.26 & & 0.38 & & 0.38 \\
\hline 0.050 & 0.23 & & 0.39 & & 0.37 \\
\hline 0.045 & 0.24 & 0.43 & 0.39 & & 0.33 \\
\hline 0.041 & 0.37 & 0.30 & 0.37 & & 0.39 \\
\hline 0.048 & 0.41 & 0.43 & 0.36 & & 0.44 \\
\hline 0.041 & 0.36 & 0.38 & 0.39 & & 0.35 \\
\hline 0.049 & 0.36 & 0.39 & 0.38 & & 0.36 \\
\hline 0.048 & 0.28 & 0.40 & 0.41 & & 0.25 \\
\hline 0.040 & & 0.39 & 0.37 & & 0.25 \\
\hline 0.046 & & 0.54 & & & 0.24 \\
\hline 0.046 & & 0.41 & & & 0.24 \\
\hline 0.049 & & 0.46 & & & 0.16 \\
\hline 0.037 & & 0.44 & & & 0.21 \\
\hline 0.054 & & 0.45 & & & \\
\hline 0.046 & & 0.46 & & & \\
\hline 0.046 & & 0.37 & & & \\
\hline 0.052 & & 0.37 & & & \\
\hline 0.049 & & 0.29 & & & \\
\hline 0.048 & & 0.26 & & & \\
\hline \multicolumn{6}{|l|}{0.053} \\
\hline \multicolumn{6}{|l|}{0.076} \\
\hline \multicolumn{6}{|l|}{0.057} \\
\hline 0.065 & & & & & \\
\hline
\end{tabular}


0.055

0.050

0.056

0.066

0.058

0.061

0.056

0.061

0.055

0.058

0.071

0.074

0.074

0.067

0.063

0.064

0.071

0.075

0.076

0.102

0.097

0.101

0.072

0.083

0.083

0.099

0.012

0.022

0.031

0.017

0.011

0.015 
Page 75 of 83

Lethaia

$$
\begin{aligned}
& 1 \\
& 2 \\
& 3 \\
& 4 \\
& 5 \\
& 6 \\
& 7 \\
& 8 \\
& 9 \\
& 10 \\
& 11 \\
& 12 \\
& 13 \\
& 14 \\
& 15 \\
& 16 \\
& 17 \\
& 18 \\
& 19 \\
& 20 \\
& 21 \\
& 22 \\
& 23 \\
& 24 \\
& 25 \\
& 26 \\
& 27 \\
& 28 \\
& 29 \\
& 30 \\
& 31 \\
& 32 \\
& 33 \\
& 34 \\
& 35 \\
& 36 \\
& 37 \\
& 38 \\
& 39 \\
& 40 \\
& 41 \\
& 42 \\
& 43 \\
& 44 \\
& 45 \\
& 46 \\
& 47 \\
& 48 \\
& 49 \\
& 50 \\
& 51 \\
& 52 \\
& 53 \\
& 54 \\
& 55 \\
& 56 \\
& 57 \\
& 58 \\
& 59 \\
& 60
\end{aligned}
$$

Lethaia - manuscript copy 
Sepiella japonica

SJ2-3
Sea of
Harima

0.28

0.23

0.24

0.21

0.16

0.13

0.09

0.05

0.10

0.14

0.17

0.14

0.15

0.17

0.15

0.19

0.20

0.24

0.20

0.25

0.22

0.22

0.27

0.25

0.21

0.31

0.25

0.31

0.27

0.30

0.29

0.34

0.30

0.31

0.32

0.35

0.34

0.34

0.37

0.32

0.39

0.34

0.39

0.35

0.35

0.37

\section{SJ2-4}

Sea of

Harima

0.15

0.12

0.11

0.08

0.10

0.06

0.09

0.11

0.12

0.22

0.20

0.19

0.19

0.22

0.22

0.20

0.20

0.22

0.21

0.22

0.26

0.18

0.22

0.17

0.21

0.27

0.24

0.21

0.26

0.32

0.24

0.32

0.29

0.38

0.37

0.36

0.34

0.36

0.32

0.36

0.35

0.31

0.36

0.36

0.35

0.32
SJ2-5

Sea of

Harima

0.30

0.31

0.10

0.17

0.19

0.28

0.11

0.12

0.17

0.16

0.11

0.11

0.14

0.17

0.19

0.18

0.18

0.14

0.17

0.25

0.25

0.25

0.23

0.19

0.26

0.24

0.28

0.21

0.25

0.26

0.28

0.32

0.31

0.31

0.31

0.34

0.34

0.32

0.34

0.33

0.32

0.36

0.33

0.32

0.34

0.34

\section{SJ2-6}

Sea of

Harima

0.17

0.22

0.16

0.18

0.17

0.15

0.13

0.10

0.08

0.07

0.10

0.10

0.08

0.17

0.12

0.16

0.21

0.14

0.19

0.15

0.19

0.16

0.20

0.20

0.22

0.23

0.19

0.30

0.21

0.22

0.22

0.24

0.26

0.23

0.25

0.25

0.26

0.25

0.26

0.26

0.26

0.28

0.34

0.31

0.31

0.29

\section{SJ2-7}

Sea of

Harima

0.17

0.14

0.20

0.22

0.12

0.11

0.11

0.09

0.08

0.11

0.13

0.13

0.18

0.19

0.16

0.09

0.11

0.25

0.16

0.16

0.19

0.19

0.21

0.19

0.22

0.23

0.24

0.24

0.21

0.23

0.23

0.28

0.24

0.24

0.27

0.33

0.25

0.32

0.29

0.32

0.31

0.31

0.36

0.31

0.31

0.32

SJ2-9

Sea of

Harima

$$
0.17
$$

0.17

0.18

0.15

0.15

0.07

0.02

0.08

0.10

0.09

0.09

0.10

0.06

0.08

0.08

0.08

0.13

0.09

0.16

0.10

0.16

0.18

0.14

0.19

0.17

0.17

0.12

0.17

0.18

0.18

0.17

0.18

0.23

0.23

0.24 


\begin{tabular}{|c|c|c|c|c|c|c|}
\hline 0.39 & 0.38 & 0.32 & 0.33 & 0.36 & 0.28 & 0.33 \\
\hline 0.32 & 0.38 & 0.37 & 0.31 & 0.35 & 0.31 & 0.34 \\
\hline 0.42 & 0.35 & 0.32 & 0.25 & 0.36 & 0.30 & 0.33 \\
\hline 0.34 & 0.38 & 0.32 & 0.32 & 0.30 & 0.31 & 0.33 \\
\hline 0.34 & 0.38 & 0.33 & 0.31 & 0.31 & 0.30 & 0.34 \\
\hline 0.34 & 0.36 & 0.36 & 0.33 & 0.33 & 0.31 & 0.34 \\
\hline 0.36 & 0.35 & 0.33 & 0.29 & 0.31 & 0.32 & 0.32 \\
\hline 0.33 & 0.40 & 0.31 & 0.34 & 0.36 & 0.26 & 0.33 \\
\hline 0.42 & 0.37 & 0.29 & 0.36 & 0.37 & 0.31 & 0.35 \\
\hline 0.41 & 0.36 & 0.34 & 0.32 & 0.35 & 0.31 & 0.35 \\
\hline 0.34 & 0.34 & 0.35 & 0.35 & 0.36 & 0.27 & 0.35 \\
\hline 0.41 & 0.35 & 0.37 & 0.36 & 0.34 & 0.35 & 0.35 \\
\hline 0.34 & 0.33 & 0.29 & 0.36 & 0.36 & 0.32 & 0.34 \\
\hline 0.38 & 0.37 & 0.34 & 0.34 & 0.34 & 0.29 & 0.36 \\
\hline 0.38 & 0.42 & 0.31 & 0.35 & 0.32 & 0.30 & 0.35 \\
\hline 0.33 & 0.36 & 0.30 & 0.28 & 0.32 & 0.32 & 0.34 \\
\hline 0.38 & 0.39 & 0.34 & 0.34 & 0.30 & 0.32 & 0.35 \\
\hline 0.39 & 0.33 & 0.30 & 0.35 & 0.38 & 0.32 & \\
\hline 0.40 & 0.37 & 0.32 & 0.32 & 0.38 & 0.34 & 0.35 \\
\hline 0.36 & 0.18 & 0.33 & 0.34 & 0.30 & 0.27 & 0.32 \\
\hline 0.34 & 0.24 & 0.30 & 0.31 & 0.39 & 0.26 & \\
\hline 0.39 & 0.27 & 0.30 & 0.35 & 0.33 & 0.29 & 0.33 \\
\hline 0.44 & 0.32 & 0.34 & 0.37 & 0.35 & 0.29 & 0.36 \\
\hline 0.37 & 0.35 & 0.38 & 0.31 & 0.35 & 0.30 & \\
\hline 0.38 & 0.38 & 0.26 & 0.33 & 0.37 & 0.31 & \\
\hline 0.39 & 0.35 & 0.34 & 0.32 & 0.36 & 0.32 & \\
\hline 0.37 & 0.38 & 0.35 & 0.32 & 0.43 & 0.31 & \\
\hline 0.35 & 0.38 & 0.33 & 0.32 & 0.34 & 0.30 & 0.34 \\
\hline 0.39 & 0.37 & 0.31 & 0.34 & 0.43 & 0.27 & 0.35 \\
\hline 0.33 & 0.43 & 0.29 & 0.35 & 0.36 & 0.32 & \\
\hline 0.37 & 0.36 & 0.31 & 0.34 & 0.35 & 0.30 & 0.34 \\
\hline 0.34 & 0.40 & 0.29 & 0.33 & 0.35 & 0.34 & 0.34 \\
\hline 0.34 & 0.38 & 0.28 & 0.40 & 0.36 & 0.28 & \\
\hline 0.35 & 0.39 & 0.24 & 0.31 & 0.41 & 0.30 & \\
\hline 0.38 & 0.41 & 0.27 & 0.38 & 0.36 & 0.30 & 0.35 \\
\hline 0.33 & 0.45 & 0.25 & 0.36 & 0.38 & 0.30 & 0.34 \\
\hline 0.33 & 0.43 & 0.23 & 0.35 & 0.37 & 0.32 & \\
\hline 0.35 & 0.39 & 0.20 & 0.37 & 0.39 & 0.28 & 0.33 \\
\hline 0.33 & 0.40 & 0.32 & 0.37 & 0.32 & 0.33 & \\
\hline 0.28 & 0.40 & 0.24 & 0.35 & 0.32 & 0.29 & \\
\hline 0.30 & 0.39 & 0.26 & 0.37 & 0.34 & 0.35 & \\
\hline 0.33 & 0.40 & 0.25 & 0.34 & 0.33 & 0.33 & 0.3 \\
\hline 0.39 & 0.40 & 0.29 & 0.36 & 0.30 & 0.32 & \\
\hline 0.36 & 0.40 & 0.28 & 0.35 & 0.30 & 0.33 & \\
\hline 0.33 & 0.41 & 0.29 & 0.36 & 0.25 & 0.30 & 0.32 \\
\hline 0.39 & 0.41 & 0.31 & 0.35 & 0.26 & 0.37 & \\
\hline 0.32 & 0.41 & 0.34 & 0.35 & 0.25 & 0.30 & \\
\hline 0.35 & 0.43 & 0.31 & 0.35 & 0.25 & 0.31 & \\
\hline 0.33 & 0.44 & 0.33 & 0.34 & 0.22 & 0.35 & \\
\hline 0.32 & 0.45 & 0.33 & 0.39 & 0.24 & 0.29 & \\
\hline 0.39 & 0.44 & 0.28 & 0.35 & 0.22 & 0.31 & \\
\hline 0.28 & 0.45 & 0.24 & 0.36 & 0.17 & 0.31 & \\
\hline
\end{tabular}




\begin{tabular}{|c|c|c|c|c|c|c|}
\hline 0.43 & 0.45 & 0.32 & 0.38 & 0.20 & 0.33 & 0.34 \\
\hline 0.31 & 0.45 & 0.25 & 0.36 & 0.23 & 0.32 & 0.32 \\
\hline 0.35 & 0.48 & 0.26 & 0.38 & 0.25 & 0.33 & 0.32 \\
\hline 0.41 & 0.48 & 0.30 & 0.35 & 0.27 & 0.33 & 0.34 \\
\hline 0.39 & 0.46 & 0.29 & 0.36 & 0.28 & 0.30 & 0.33 \\
\hline 0.30 & 0.46 & 0.28 & 0.40 & 0.25 & 0.35 & 0.33 \\
\hline 0.37 & 0.44 & 0.30 & 0.37 & 0.27 & 0.33 & 0.34 \\
\hline 0.37 & 0.35 & 0.39 & 0.34 & 0.27 & 0.35 & 0.32 \\
\hline 0.34 & 0.35 & 0.34 & 0.41 & 0.31 & 0.33 & 0.34 \\
\hline 0.34 & 0.27 & 0.35 & 0.39 & 0.31 & 0.36 & 0.34 \\
\hline 0.37 & 0.23 & 0.35 & 0.39 & 0.24 & 0.30 & 0.33 \\
\hline 0.36 & 0.25 & 0.35 & 0.39 & 0.26 & 0.36 & 0.35 \\
\hline 0.36 & 0.24 & 0.35 & 0.39 & 0.31 & 0.37 & 0.35 \\
\hline 0.40 & 0.21 & 0.37 & 0.40 & 0.29 & 0.33 & 0.37 \\
\hline 0.31 & 0.18 & 0.32 & 0.37 & 0.31 & 0.34 & 0.35 \\
\hline 0.36 & 0.23 & 0.34 & 0.34 & 0.34 & 0.40 & 0.36 \\
\hline 0.32 & 0.08 & 0.33 & 0.42 & 0.26 & 0.36 & 0.34 \\
\hline 0.31 & 0.12 & 0.34 & 0.37 & 0.29 & 0.39 & 0.35 \\
\hline 0.33 & & 0.35 & 0.40 & 0.31 & 0.35 & 0.37 \\
\hline 0.31 & & 0.35 & 0.39 & 0.30 & 0.38 & 0.36 \\
\hline 0.27 & & 0.42 & 0.39 & 0.39 & 0.39 & 0.38 \\
\hline 0.26 & & 0.38 & 0.37 & 0.31 & 0.38 & 0.36 \\
\hline 0.25 & & 0.38 & 0.37 & 0.30 & 0.34 & 0.35 \\
\hline 0.28 & & 0.48 & 0.42 & 0.30 & 0.43 & 0.36 \\
\hline 0.21 & & 0.45 & 0.36 & 0.29 & 0.39 & 0.35 \\
\hline 0.21 & & 0.41 & 0.44 & 0.25 & 0.39 & 0.32 \\
\hline 0.22 & & 0.41 & 0.44 & 0.19 & 0.36 & 0.34 \\
\hline 0.19 & & 0.37 & 0.40 & 0.26 & 0.33 & 0.32 \\
\hline 0.19 & & 0.41 & 0.43 & 0.35 & 0.38 & 0.33 \\
\hline 0.21 & & 0.41 & 0.38 & 0.29 & 0.37 & 0.33 \\
\hline 0.20 & & 0.44 & 0.43 & 0.32 & 0.37 & 0.35 \\
\hline 0.18 & & 0.42 & 0.40 & 0.33 & 0.43 & 0.35 \\
\hline 0.17 & & 0.43 & 0.44 & 0.36 & 0.39 & 0.36 \\
\hline 0.16 & & 0.41 & 0.39 & 0.34 & 0.44 & 0.38 \\
\hline 0.19 & & 0.41 & 0.48 & 0.37 & 0.37 & 0.37 \\
\hline 0.21 & & 0.41 & 0.44 & 0.38 & 0.38 & 0.37 \\
\hline 0.19 & & 0.32 & 0.45 & 0.30 & 0.37 & 0.33 \\
\hline 0.09 & & 0.26 & 0.35 & 0.36 & 0.35 & 0.30 \\
\hline 0.20 & & 0.23 & 0.35 & 0.42 & 0.31 & 0.33 \\
\hline 0.27 & & 0.31 & 0.30 & 0.43 & 0.28 & 0.32 \\
\hline 0.19 & & 0.39 & 0.27 & 0.38 & 0.27 & 0.30 \\
\hline 0.28 & & 0.38 & 0.22 & 0.43 & 0.25 & 0.32 \\
\hline 0.25 & & 0.34 & 0.27 & 0.48 & 0.21 & 0.33 \\
\hline 0.23 & & 0.30 & & 0.46 & 0.28 & 0.35 \\
\hline \multirow[t]{7}{*}{0.16} & & 0.16 & & 0.45 & & 0.29 \\
\hline & & & & 0.47 & & 0.42 \\
\hline & & & & 0.48 & & 0.39 \\
\hline & & & & 0.31 & & 0.29 \\
\hline & & & & 0.37 & & 0.37 \\
\hline & & & & 0.26 & & 0.26 \\
\hline & & & & 0.19 & & \\
\hline
\end{tabular}


Page 79 of 83

Lethaia

$$
\begin{aligned}
& 1 \\
& 2 \\
& 3 \\
& 4 \\
& 5 \\
& 6 \\
& 7 \\
& 8 \\
& 9 \\
& 10 \\
& 11 \\
& 12 \\
& 13 \\
& 14 \\
& 15 \\
& 16 \\
& 17 \\
& 18 \\
& 19 \\
& 20 \\
& 21 \\
& 22 \\
& 23 \\
& 24 \\
& 25 \\
& 26 \\
& 27 \\
& 28 \\
& 29 \\
& 30 \\
& 31 \\
& 32 \\
& 33 \\
& 34 \\
& 35 \\
& 36 \\
& 37 \\
& 38 \\
& 39 \\
& 40 \\
& 41 \\
& 42 \\
& 43 \\
& 44 \\
& 45 \\
& 46 \\
& 47 \\
& 48 \\
& 49 \\
& 50 \\
& 51 \\
& 52 \\
& 53 \\
& 54 \\
& 55 \\
& 56 \\
& 57 \\
& 58 \\
& 59 \\
& 60
\end{aligned}
$$

Lethaia - manuscript copy 
Lethaia

Page 80 of 83

$$
\begin{aligned}
& 1 \\
& \begin{array}{l}
2 \\
3
\end{array} \\
& 4 \\
& 5 \\
& 6 \\
& 7 \\
& 8 \\
& 9 \\
& 10 \\
& 11 \\
& 12 \\
& 13 \\
& 14 \\
& 15 \\
& 16 \\
& 17 \\
& 18 \\
& 19 \\
& 20 \\
& 21 \\
& 22 \\
& 23 \\
& 24 \\
& 25 \\
& 26 \\
& 27 \\
& 28 \\
& 29 \\
& 30 \\
& 31 \\
& 32 \\
& 33 \\
& 34 \\
& 35 \\
& 36 \\
& 37 \\
& 38 \\
& 39 \\
& 40 \\
& 41 \\
& 42 \\
& 43 \\
& 44 \\
& 45 \\
& 46 \\
& 47 \\
& 48 \\
& 49 \\
& 50 \\
& 51 \\
& 52 \\
& 53 \\
& 54 \\
& 55 \\
& 56 \\
& 57 \\
& 58 \\
& 59 \\
& 60
\end{aligned}
$$

Lethaia - manuscript copy 
standard

deviation

0.056

0.059

0.047

0.041

0.028

0.061

0.040

0.030

0.046

0.052

0.035

0.032

0.045

0.049

0.049

0.060

0.053

0.055

0.048

0.066

0.036

0.040

0.049

0.046

0.046

0.045

0.053

0.056

0.051

0.050

0.043

0.053

0.042

0.053

0.055

0.061

0.049

0.047

0.059

0.056

0.051

0.028

0.045

0.033

0.029

0.025 
Lethaia

Page 82 of 83

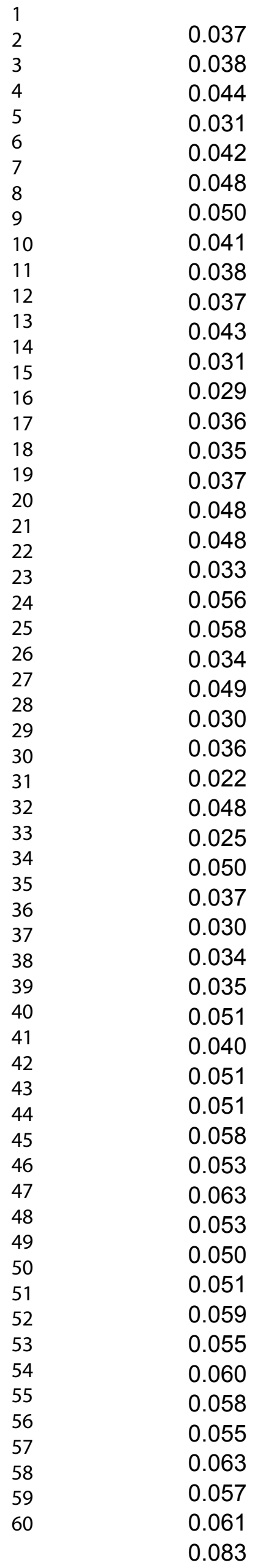

Lethaia - manuscript copy 
Page 83 of 83

Lethaia

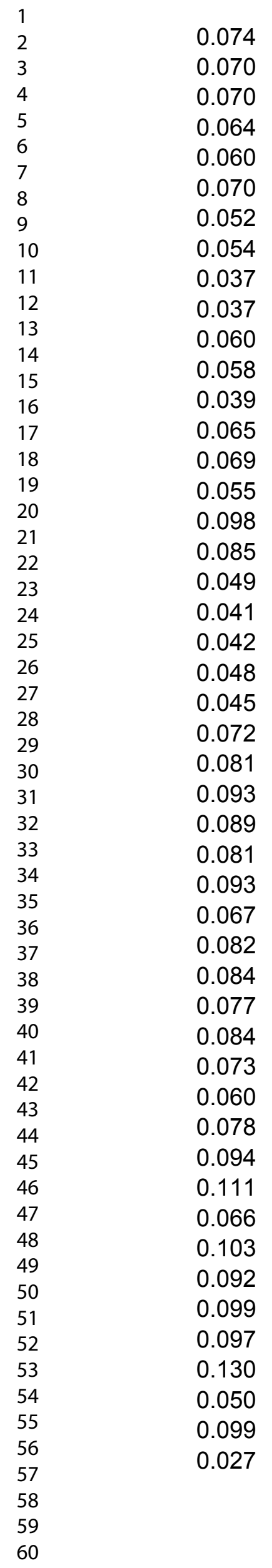

Lethaia - manuscript copy 